-1Wh

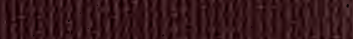
V3.

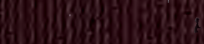

4.

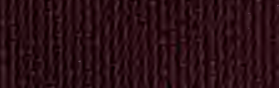




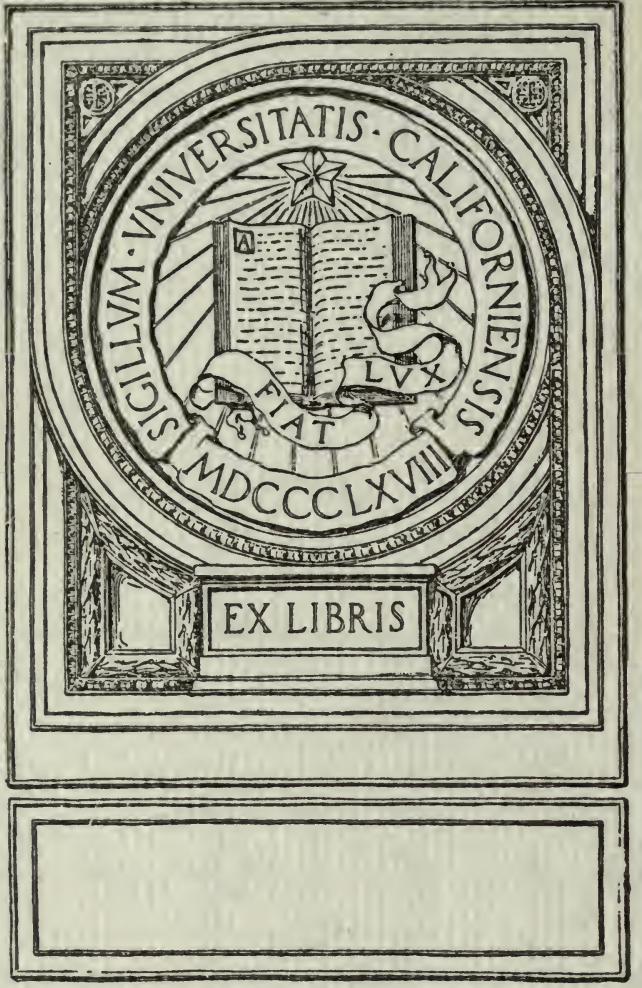



Digitized by the Internet Archive in 2007 with funding from Microsoft Corporation 


\section{HUNTING CAMPS}

\section{IN WOOD AND WILDERNESS}

BY

H. HESKETH PRICHARD, F.Z.S.

AUTHOR OF "THROUGH THE HEART OF PATAGONIA"

"WHERE BLACK RULES WHITE," "THROUGH

TRACKLESS LABRADOR," ETC.

WITH A FOREWORD BY

FREDERICK COURTENEY SELOUS

Gold Medallist of the Royal Geographical Society 


\section{SK31 \\ P7}

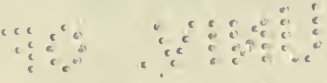

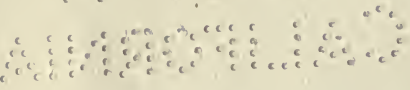




\section{FOREWORD.}

IT is some years now since I first made the acquaintance of Mr. Hesketh Prichard, who had then only just returned from his great journey through the unexplored wilds of Patagonia, a really remarkable achievement for so young a man. At that time Mr. Prichard was perhaps better known to his fellow-countrymen as a first-class cricketer and joint author with his mother of many popular works of fiction than as an explorer and hunter, and it was as a cricketer that I first came to know him at all intimately, for he was good enough during several successive seasons to bring down a team to play against the village eleven of which I was, and indeed still am, the President. In the intervals of our cricket we talked big game, and appraised the worth of the caribou and moose heads in my collection, which I had then recently brought from Newfoundland and the Yukon Territory of Canada, and Mr. Prichard's young enthusiasm, whether for cricket or big-game hunting, always did me good, and it is this same quality in the pages of the book, for which these few lines will serve as an introduction, which has given them a charm for me which I do not always find in accounts of shooting trips. I have read every chapter in this book with very great interest. Those on caribou hunting in Newfoundland have appealed to me very strongly, because I also have wandered very widely over the barrens and across the lake-strewn wastes of that wild and beautiful 
land in search of the same broad-antlered stags; whilst on the other hand the descriptions of Mr. Prichard's hunting experiences in Patagonia, in Labrador, in Norway, and in Eastern Canada have all given me the greatest interest, because I still have hopes of following his footsteps into, at least, some of the more accessible of these hunting grounds of which he has been the pioneer.

In reading this book-and I trust it will be widely read both in this country and on the other side of the Atlantic -no one can fail to be impressed with the fact that $\mathrm{Mr}$. Prichard has worked very hard for and well deserved all the fine trophies which have fallen to his rifle. He has never killed wantonly, but on the contrary over and over again has spared the life of a thoroughly warrantable stag, in the hope-which was as often as not disappointed-of meeting with a better. Whether in Patagonia, Norway, Newfoundland, or here on our Worplesdon cricket ground, Mr. Prichard has always played the game as a true sportsman should. What can I say more except to express the hope that this book will be widely read and that the Author's forthcoming hunting and exploring expedition into the wilds of Labrador will meet with all the success which I am sure it will so well deserve.

WORPLESDON, SURREY,

F. C. SELOUS.

May 25th, I9IO. 


\section{PREFACE.}

A PORTION of some of the chapters in this volume has appeared in the form of articles in Blackwood's Magazine, Cornhill, and Fry's Magazine, and I wish here to make my acknowledgments to the Editors of these periodicals.

The hunting districts I have described in the following pages fall into two categories. They are either, as in the case of Norway, Canada, and Newfoundland, within easy distance of Great Britain, or else they are altogether out of the beaten track. A considerable part of the ground covered in Patagonia, Labrador, and even in Newfoundland, had not previously been visited by sportsmen, and there the conditions remain to the best of my belief unaltered in the short time which has elapsed since I passed through them.

A few statistics may be of interest. Apart from the game which I was forced to shoot in order to feed a comparatively large party in crossing Patagonia, I find that during the trips dealt with in this book, as far as I can calculate, I fired at an animal on an average once for every six days' hunting. I mention this because an idea seems to be prevalent among a section of the community that big game shooting is inseparable from slaughter on a large scale. 
viii

\section{PREFACE.}

I must cordially express my gratitude to Mr. F. C. Selous for the "Foreword" which he has written for these pages and for the kindness and help that I have always received from him.

\section{H. HESKETH PRICHARD.}

Prae Wood, St. Albans,

June Ist, I9IO. 


\section{CONTENTS.}

I. The Pampas of Patagonia . . . . II

II. Hunting-Days in the Cordillera of the ANDES . . . . . . . . 34

III. ON THE LABRADOR . . . . . . 58

IV. A Fall Hunting Trip in Newfoundland . 8I

V. October AND November Hunting NEAR Middle Ridge. • . . . . . II2

VI. Ań Elk-Hunting Season in Norway . . I42 VII. Moose-Hunting and Moose-Caling IN Canada . . . . . . . . . . . I68 VIII. A September Trip upon the Gander River, NEWfOUNDLAND • . . . . . Igo IX. Caribou-Hunting in Timber and Brûlée • 214 X. Further Days after Mainland Caribou . 238 INDEX • • • • • • • • . 25 I 



\section{HUNTING CAMPS IN \\ WOOD AND WILDERNESS.}

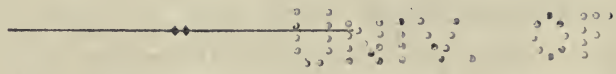

CHAPTER I I

THE PAMPAS OF PATAGONIA.

DERHAPS the chief charm of Patagonia lies in its absolute unlikeness to any other land north or south. The plains, rising in vast terraces across the continent from the low coasts on the east to the mountain ranges on the west show grass, on all sides grass as far as the eye can reach. Not green inviting grass, but yellowish, harsh and prickly, which leaves spines sticking into the fingers. All vegetation other than the grass is dwarf, stunted by the unceasing winds which sweep over the open country. Leagues upon leagues of califaté thorn, no higher than a man's waist, broken now and again by pebbly patches sparsely set with mate negra, innumerable pools and huge tracts of glacial detritus are all undergrown and overflown and surrounded by this sea of grass. . . . It forms a very desolate and forbidding landscape, yet it is one which lays a strong hold on the imagination and the memory; once you have ridden across those lonely plains, you often feel a desire which sometimes amounts to a craving to go back and ride across them again. The feeling brings to mind the story told in the ancient chronicles of Magellan, who 147 
decoyed on board his ship a Tehuelche Indian, one of that race whose "huge footsteps" the Spaniards found and marvelled at when first they touched upon the Patagonian sands. The prisoner was destined to be presented as a gift to the King of Spain by his great sea-captain, but the ship had hardly lost sight of the coast when the poor savage pined and died. Had he survived one is apt to wonder what would have been his outlook upon Spain. Belonging to a primitive people, few in number, bred in a land of limitless solitudes, How would he have faced the populous cities, the varied inagnificence that waited for him across the sfa? The cortrasts must surely have cowed and overwheincd him. The traveller in Patagonia to-day undergoes the inverse experiences. As soon as he leaves behind him one or other of the little settlements, he finds himself in circle after circle of flat and arid regions, and whether on foot or in the saddle, seems to be himself always the highest point between the horizons.

The fauna of Patagonia are as distinctive as the scenes they inhabit. In the course of a spring, summer, and autumn it was impossible to gain adequate experience of more than a limited portion of the immense area of Southern Argentina. My course lay in the land of the Tehuelches, south of the 4oth parallel of latitude, between the Rio Deseado and the Straits of Magellan, and there the pampas offered wide and in many places absolutely virgin huntinggrounds, over which roamed herds of guanaco, as well as of wild cattle, two sub-species of puma, the cavy or Patagonian hare (Dolichotis patagonica), and everywhere over the plains the common grey fox or hoary dog was to be found in almost inconceivable numbers. I was too far south to touch the range of the jaguar, which is said to be marked by the Rio Negro, north of which river I never hunted.

The grey fox, although not an animal of actual interest 
to the sportsman, cannot, however, be ignored, for he is an intolerable nuisance, gnawing through the sogas of the horses and thieving in so inveterate a fashion, that hardly a camp can be made without its occupants paying toll of their belongings to his tribe. Nothing escapes the fox's voracious appetite; a raw hide, a saddle, natural history specimens even when cured with arsenical soap, all if left within reach of a fox's leap are pulled down and devoured.

But as numerous as the foxes, and far more apparent to the traveller's eye, are the guanaco. The herds of this strange animal are distributed over the whole area of the pampas, and though infinitely more plentiful in certain favoured districts, such as the vast tablelands to the southwest of Lago Buenos Aires, are to be met with in greater or less numbers in almost every part. Exactly as the caribou upon the same degree of latitude north, so is the guanaco to the south, the prop of life to the nomadic tribes. The guanaco do not, however, migrate en masse; they only move in the case of isolated herds from their summer haunts on the high tablelands to winter in the river valleys or about the shores of the lakes.

If the sporting qualities of an animal are to be judged along the usual lines, the guanaco must take high place. This somewhat dogmatic statement presupposes that the hunter's ideal is a chase in which he can see his quarry in the open, can match his intelligence against its instinct, and win or lose the day on his merits. Beyond this, again, there is the definition of Mr. Bromley Davenport concerning the real and the artificial in sport, by which he defines the real as " the pursuit of the perfectly wild animal on its own primeval and ancestral ground, as yet unannexed and unappropriated in any shape or way by man ; where, therefore, no permission can be asked, granted, or refused; where the wild illimitable expanse is free to all, human or animal, and the first come is the first served." In its Patagonian 
environment the guanaco fulfils this ideal. There are as yet no ring-fences and but little barbed wire in the interior, where indeed the hunter may ride for weeks, and even months, and perhaps never see anything save the landscape and the game upon it.

Of course the guanaco lacks one, and that the most important of the desiderata of a quarry-he carries no trophy. The black face and the scarred neck of one old fighting buck is very like that of another, so that after the hunter has shot three or four, he has before him no alluring prospect, such as the chance of securing a particularly fine or unusual specimen, a hope which, in the case of horned game, serves to keep his interest always at high-water mark. But, despite this fact, the chase of the guanaco and the fair stalking of a big buck sometimes presents difficulties which can be relied on to keep the hunter's enthusiasm well awake.

Those who have seen the animal as he appears on the farms near the coast can form no idea of the wariness of his brethren in such spots as the cañadon * of the Senguerr River. Close to the coast the considerable number of guanaco that inhabit the allotted lands are little molested by the shepherds who come and go among them, for it is certain that while a man can procure mutton he will never hanker after the dry and stringy meat provided by the wild animal. From time to time, when the herds of the latter grow too numerous, a campaign is organised against them, but the lesson learned in the three or four days of war soon passes away, so that during the greater part of the year they remain comparatively tame and accessible. But in the cañadon of the Senguerr, through which I travelled in October, it was impossible to approach openly within a mile of any animal. It is here that the Tehuelche Indians have erected their permanent toldos, and as they habitually 
hunt on horseback and with hounds, generally converging upon the herds in circles and from all points of the compass, the guanaco of that region has learned the art of selfpreservation in all its details. His long neck and his habit of invariably upon the approach of danger seeking and keeping to the highest ground in sight, his sense of hearing, which is exceedingly well developed, and his nose that is only inferior to his powers of vision, make him a most difficult and sporting quarry.

There are further one or two other small points which add their quota of hindrance to the chances of an easy success. The fact that almost every acre of ground carries its crop of low thorn bushes-and even when these are absent the sharp blades of the harsh grass can make a very painful wound-renders stalking a task not altogether without its discomforts. That cover is represented only by the walls of cañadones, an occasional hummock or little patches of maté negra hardly eighteen inches high, is also all in favour of the guanaco's side of the game. When to these things is added the fact that a guanaco can carry away as much lead as almost any animal of its size, it will be seen that the sportsman may spend many fruitless hours before he can succeed in attaining any great success in this particular form of pastime.

But it so happened that when I was travelling in this region the shooting of guanaco was by no means a pastime. We were a party of eight, and beyond the emergency rations which we carried to ensure us against the chance of crossing a gameless tract, we had nothing save a small allowance of flour between us and hunger. Besides this, I wished to shoot half-a-dozen old bucks, or machos as they are termed in that country, for my collection. Our travels were carried out on horseback, and at this period our advance was a good deal hindered by the continual straying during the night time of one or many of our troop of horses. The time 
spent by the gauchos in tracking and recovering these often left me many hours to spare for sport, and day by day I learned more and more to respect the intelligence of the guanaco. The experience of a typical day may perhaps be of interest.

It is sunrise, and I have just discovered that out of our sixty horses only forty-six remain to us; the rest have strayed in the night and may be anywhere within three or four leagues, as the tracks give ample evidence that the madrina, or brood mare, which the horses of each tropilla are trained to follow, has broken her hobbles and gone off eastward at a trot. A couple of gauchos will start immediately to track them, while there is plenty of work for the rest of the party in camp, where a number of new maletas or packs have to be fashioned to replace those that hard usage and the exigencies of travel have worn out. A few skins are very necessary for this work, and so it is with the prospect of a threefold use for any guanaco I can shoot that I set out. We need the meat to eat, the skins to make packs for a part of our outfit, and I am eager to obtain a skin or two as the animals approach their summer pelage.

Soon the camp is left behind and, looking back on it, the fact strikes me that it presents a picture very unlike the idea of a camp which is prevalent in any other countries which I have visited. A mere pile of baggage, an open fire and the blankets and bedding airing in the morning sun, a troop of horses feeding in the marshes by the river, and on all sides the low cliffs of the valley shutting in the horizon. Turning my back upon camp, I ride out with thirteen clear hours before me. The country is quite new to me, and apart from the fact that the river gives no hint of a ford by which to cross it, the nature of the ground on the southern bank looks more favourable for my purpose. As I ride slowly along, I put up a brace of upland geese from the bed of the stream, and soon after I perceive a game-track lead- 
ing along the side of the cañadon; up this my horse climbs until I find myself upon a broad and stony tableland, which stretches to the verge of sight. Save in one direction, it seems to be absolutely level, but on its south-western edge rise a few low rolling hummocks that look more promising than the rest of its arid flatness. Towards these I make my way, and during the course of my ride, which occupies nearly an hour, I see nothing but a single chimango hawk that circles in the air above me and finally flies off in the direction of the river.

On approaching the ridge of hummocks, I see that they lie upon the other side of a cleft in the plain, a cañadon full of coarse grass and scrub growing about a dry riverbed. The sides are very precipitous, but that is a small matter to the Patagonian horse, who, provided he be not asked to jump anything, will carry his rider in safety across almost any natural obstacle that may arise. The horse I am riding to-day is known as the cruzado, so called because of the cross markings he shows, his near hind leg and the off fore each bearing a white stocking. He is one of the three horses out of the large number I had to do with in Patagonia that could be trusted to fulfil all the requirements of a good shooting horse. Having dismounted, I drop the reins over the cruzado's head, and prepare to leave him with an easy mind, for I know that even if I do not return for hours, he will inevitably remain quietly within a hundred yards of the same spot. In a country of vast distances this is a very useful acquirement, as few situations can be more trying than that of a hunter, who having dismounted for a stalk, returns from it so see his horse disappearing in the distance, stirrups swinging and reins flying, towards the camp, which is perhaps ten or fifteen miles away.

No sooner have I reached the bottom of the cleft, than I see three ostriches, as Darwin's rhea is locally called. They have long since spied me and are already nearly half 
a mile away. Suddenly they turn and run up the steep cliff of the cañadon; are silhouetted for a moment against the blue sky before they disappear over the edge of sight. These ostriches, to continue the Patagonian name, are without exception the wildest and most difficult quarry against which I have ever matched the modern long-range rifle. I have heard it stated as a fact that there is no animal whatever which can, in any way, compare in quickness of sight with certain birds. I have believed this from very early days when I used to stalk curlew among sand dunes with a rifle. I had but to show a couple of inches of cap, and even if it were motionless, the birds noticed it at once and were off. The ostriches possess the same extraordinary certainty of vision. Added to which they seem to be devoid of the smallest particle of curiosity, a quality which is often the hunter's best ally. I have seen them run on my appearance while they were still on the furthest verge of sight. There is not much to shoot at in an ostrich, and one's chances are generally obtained at fairly long range; certainly I fired at very many more of the birds that came to bag. An ostrich when hit through the body, however severely, almost invariably makes a short rush of from fifty to one hundred yards before falling dead. During the eight months spent in the country frequented by ostriches and seeing birds on an average at least once a day, and often attempting to get within shot, I secured only twentyfour, and of these I rode down eight with dogs, leaving a total of but sixteen to the rifle.

As was to be expected, I am not destined to get a shot at the three birds that had escaped out of the cañadon, for though I follow them to the point where I had seen them disappear, it is only to find they have vanished altogether among the ridges of the hummocks which had attracted me from the riverbank. Some of these hummocks are covered with grass at the base, but nearly all of them 
run up into hard, bare, sun-baked earth towards their summits.

I leave the cruzado to feed while I scramble to the top of the nearest hummock, and I almost immediately become aware that my horse's movements are being watched by an animal that can only be a guanaco buck. It stands at gaze about six hundred yards from me, but so far has not seen me against the hillside, for I have not yet reached the summit-line. As I see no chance of getting nearer, I lie down and consider the position. The guanaco stands directly facing me, and was evidently in the act of descending a hollow between two of the small hills when his suspicions were aroused. I soon find him with my telescope to be as I expected a very large dark-faced buck, and seeing that he is on the alert I have just picked up my rifle when another buck walks over a ridge within seventy yards on my right. I quickly get the sights in a line with the last comer's shoulder and pull the trigger. $\mathrm{He}$ at once makes off at a gallop, giving no sign whatever of being hit, but my second bullet cuts him down. Then I turn my attention to the first guanaco and find that he has climbed to the higher of the two summits above him, where he pauses for a moment broadside on, clearly outlined against the sky. I fire, but my bullet falls short, knocking up a spurt of sand beneath his body. The old buck gives me no second chance, but vanishes in a twinkling over the brow of the hummock.

Walking down to the guanaco I have killed, I soon satisfy myself that the first shot had taken effect, as well as the second, and that either would have proved fatal. After gralloching the animal, I collect dry thorns and grass and light a fire, in the hope that the smoke may be observed by one of my gauchos, who would in that case instantly ride it down. Even had I not left orders to that effect at the camp, they would not fail to ride down a smoke, for the gaucho's most strongly marked characteristic is 
curiosity : he loves to meet his kind and to hear the news which in the wide solitude of such countries passes from mouth to mouth. It was in this way that the intelligence of Queen Victoria's death travelled through the far interior of Patagonia in an astonishingly short space of time.

Sometimes, however, as might be expected, pampa news is not very reliable, as, for example, when in the year above alluded to a report came up from the coast that the Russians had invaded India and the French were in London. This rumour may or may not have been traceable to a couple of prospectors, who, having fought under Villebois de Mareuil in South Africa and been wounded there, afterwards took ship in one of the returning horse-boats to Buenos Aires, from whence they had drifted down into Patagonia.

I cut up the guanaco and place it as far as circumstances will permit beyond the reach of the ubiquitous foxes, and then, retracing my steps to the cruzado, I mount and resume my search for game. In this I am almost immediately successful, for as I round the last of the hummocks, I notice a cavy springing across a dry lagoon. He has not seen me and in a second I am out of the saddle. The cavy is a curious animal not unlike an English hare, but twice as large ; its method of progression, however, is rather that of the kangaroo. As the cavy approaches the further side of the lagoon, he stops and sits up on his hind-legs, his small and delicate fore-paws looking strangely out of proportion. For once the cover is good, for there is near me a patch of dry, white thorn reaching to within fifty yards of the edge of the mud lagoon. On my left hand I slip a kind of rough, fingerless glove made of skin, which is a great protection, and crawl up under the thorn bushes. Peering round them, I see the cavy is still sitting at about a hundred yards' distance. I slip a solid bullet instead of the soft-nosed one into my rifle and shoot the cavy through the shoulders. He turns out to be rather a large male, weighing, as far as I can 
judge, about I9 lbs. Very pleased at my good fortune, for the cavy is excellent eating, I tie him to the back of my saddle and proceed upon my way.

For two or three hours I ride, sometimes across bare tablelands, sometimes through cañadones, without any sight of game. Not that the country is absolutely barren of life, for foxes are lying in the thickets, and scavenger birds, chimangos and coranchos, drowse in the noonday heat upon the low bush, but of guanaco I see no sign. The sun climbs higher and higher, the wind still blows with the steady roar that has continued with rare intervals through the months I have spent in Patagonia and is destined to continue through the months I am yet to spend there. The cruzado is a first-rate walker, my country saddle of rugs and skins is exceedingly comfortable, the circle of sight is always enlarging, or I should rather say changing, mirages, sketched as it were in black and blue pen-strokes, flicker and fade on the horizon, taking now the shape of a reflected landscape, again that of a solitary rider-myself.

At length I come to a cañadon deeper and wider than any $I$ have yet seen, the grass in it is green marsh-grass, and a narrow stream of water trickles through it. I ride down into the valley and off saddle, place my horse-rugs to dry, rub down the cruzado and turn him loose to graze. Then I go to my saddle-bags and make a far from cheering discovery. I have forgotten to bring any lunch, and six hours in that upland air have made me very hungry. I am just debating with myself the choice between no lunch and a hastily-cooked hindquarter of cavy; when down the stream I hear the honk of geese. I catch the cruzado, slip on his bridle, throw a rug over him and ride off to find the birds. Round the first bend I come in sight of them, two ganders with white backs and grey breasts, two brown females with their chestnut heads-upland geese. The stalk is easy enough, the Patagonian goose not having learned the wis- 
dom his congeners acquire in other regions of the earth, so I get within eighty yards. I pick the nearer of the brown females as she will be tenderer, put in a solid bullet, take a fine sight and-miss her handsomely. The geese rise and swing off down stream.

Regretfully, I retrace my steps, build a little fire, and cutting off part of the cavy's hindquarter prepare a roast, skewer it camp-fashion upon sticks which I drive into the ground opposite the hottest part of the fire. While I wait for it to cook, I fall asleep, which does not very much matter, as the cruzado will be all the fresher for a two hours' off saddle. At length the roast is cooked and eaten, the two hours of rest gone, and I am once more in the saddle.

I now begin to bear northwards, as I want to strike the valley of the Senguerr River, which lies as far as I can judge about eight or nine miles off in that direction. In Patagonia no one uses the word mile, the distances are so great that all reckoning is counted in leagues; ten leagues is held to be a good day's journey with pack-horses. Smaller distances are designated as parts or fractions of a league, a habit curiously at variance with that common in Lower Canada, where the settler or trapper will often define his position by saying, "I was within two acres of the outlet of the lake." But then farmland, even in vast Canada, is reckoned by the acre, whereas in sterile Patagonia no farmer could make a living on less than five square leagues.

The landscape through which I ride in the afternoon is much the same as that I had passed over in the morning, and it is not until I again come in sight of the river that I see any game. As I descend the barranca cliff of the cañadon, I discover a herd of eight guanaco on the top of the cliff on the opposite bank; they are a long way off, but, are sharply visible against the sky. I am just wondering whether they are worth a swim across the stream, which is not very wide, when suddenly two other guanaco appear 
on my side of the water. As I am about to dismount, they gallop wildly, with the extraordinary galvanic contortions peculiar to these creatures when descending a steep place, down the barranca and out into the marsh-grass by the river. I now see a chance of cutting them off, as in front of them the river turns in a loop ; my horse is comparatively fresh, and I am on hard ground, as I think.

The cruzado enters into the spirit of the game, and in an instant we are flying along the cliff. The guanacos start at the same moment and make off straight down the valley. Inside half a mile they will be stopped by the loop of the river, when they must either plunge into the water or break back and cross my front at close range. They travel three parts of the distance before they perceive the trap, then double instantly and break back. I have but three hundred yards to go, they have a similar distance. I shall have time to dismount and get a steady shot as they cross broadside. My eyes are fixed on the leading buck, a big, blackfaced fellow; the cruzado has seen them too, and knows exactly what is expected of him. He has a turn for speed, and my little trick seems likely to succeed, when I suddenly find myself first in the air and next in a califaté bush ; indeed for a second or so I am not sure where I am. Then I crawl out with a bleeding nose, but no more serious damage, to find the cruzado, looking curiously fore-shortened, still struggling to extricate himself from a pit of soft, whitish clay, into which his front-legs have sunk to the shoulders. Meantime the guanaco have bounded past, up the barranca and out of sight.

After clearing the cruzado and myself as well as I can from the marks of the adhesive clay and-a much more lengthy proceeding - freeing the barrel of my rifle from mud and slime, I notice that it is growing late and turn towards camp. Both my horse and I have been considerably sobered by the rather crumpling fall, and now jog along at a pace 
which precludes the likelihood of further mishaps. For a couple of miles we travel thus quietly upon our way, flushing a large number of snipe and two or three companies of Chilian widgeon; then, leaving the river, I once more ride up the barranca to spy the tableland.

It is a fortunate move, for while I am still fifty feet from the top, I hear the challenging neigh of a guanaco buck. I leap off, pull the reins over the cruzado's head, and see that thoroughly reliable animal at once turn his attention to tearing up mouthfuls of grass. Sure that, notwithstanding his uncomfortable position upon a hillside sloping some thirty degrees, he will not move many paces away until I return, I creep upwards until I can look over the edge of the cliff. About three hundred yards ahead a herd of some thirty guanaco are standing. The wind, though it might be more favourable, will probably serve, and the guanaco are now moving away across the mesa. I run along under the cliff to a bush, which I have marked as the handiest; when I reach it I slowly raise my head to reconnoitre. The guanaco are grouped together about two hundred yards off. I pick out a good buck standing alone ; a yeld doe would be better for my purpose, but I never could bring myself to shoot at one as long as there was a buck to take its place, and after waiting a moment to get my breath, I press the trigger. The buck gives a convulsive start and dashes forward as an animal often will when shot through the heart.

Knowing he will need no second bullet, I transfer my attention to the rest. At first, not having located the shot, they bunch together in alarm, and then one breaks away on the left. As soon as he is clear, I swing my sight on to him but do not fire, for I recollect that it is already late in the afternoon, and by morning the foxes will have spoilt the meat, for I cannot carry more than one animal to camp. The herd break in all directions, a yearling and a doe come straight at me, I rise and they swerve, a buck crashes down 
the barranca within fifty yards, the remainder of the herd are scattered to the four winds, leaving me to reflect on having once more proved the truth of the Greek saying, that "to-day the gods are with the hunted, to-morrow with the hunter."

By the time I have cut up the dead buck, the evening is beginning to draw on. I make an unsightly but eminently welcome pack of the meat and skin which the cruzado permits me to cargo up, and then we set out determinedly for camp. On our way there, no events of any interest occur, and it is just turning dusk when, rounding a scrap of the barranca, I see the smoke of the camp-fire, and between it and me a little troop of six horses with the black mare, which I learn later that the gauchos have found a dozen miles away up the black trail.

From the description given above it will be seen that although the pampas possess no animal that carries a trophy, yet a day spent upon them with the rifle is capable of yielding excellent sport, a fact perhaps enhanced by the knowledge that so far very few sportsmen have visited them. Indeed, with the exception of Captain Chaworth Musters, of the Royal Navy, who in 1876 roamed all over the south of Patagonia in company with a tribe of Tehuelches, it would seem that this region is one of the rare parts of the earth to which the British sportsman has not been attracted. The voyage is long and the fauna do not present any great variety, yet guanaco, wild cattle, ostriches, and pumas exist upon its pampas in vast numbers. Having described a day with the rifle alone, it will be well to turn to an even more exhilarating method of hunting pampa game, that is with horse and hound.

Before leaving Buenos Aires I had purchased a fawncoloured hound, an imposing-looking creature, big enough and fast enough, one would have thought, to pull down any macho, however large or strong. This hound, Tom, accom- 
panied me on the greater part of my journey, and, in spite of some shortcomings, was considerably the most distinguished of our pack. For as time went on various dogs joined the camp, Bian, a big lurcher belonging to one of my Welsh peones; Chichi, a smaller animal, that was handed over to me because her sore feet made her useless to her master, who was travelling fast; and a large black greyhound which I procured later.

Some of the finest runs I enjoyed came in the neighbourhood of Lake Buenos Aires, which lies in the very heart of Patagonia, when Tom and Chichi were the only dogs on whom I could rely. The very first guanaco that Tom had experience of was a very old buck at which I obtained a shot but struck too far back. I at once slipped Tom, who ran into the guanaco within three hundred yards, when the animal fell dying. Tom was much elated, and obviously placed the death of the guanaco to his own sole credit, with the result that as we were riding back to camp he went off in chase of a second buck. This time, notwithstanding an excellent start, he had a much longer run, but at length came upon terms with his quarry, when the guanaco knocked him backwards with a tremendous and well-aimed kick on the head. Tom was young, and, though he was always ready thereafter to chase guanaco, it was some months before he got over his experience, but invariably ran cunning, leaving first hold to the other dogs. In spite of this he was of immense use, for in a few bounds he would leave the lurchers and cross-breeds far behind and would quickly turn the quarry.

One afternoon, having made an early camp, I caught a fresh horse, the zaino or brown, a considerably smaller animal than the cruzado and equally useful for shooting, having in addition a turn for speed that was quite remarkable. He was, however, only just up to my weight, and consequently was not ridden except for half-days, and had 
about the easiest time of any in the troop. He had, of course, his peculiarities, one of which was that in no circumstances could he be persuaded to carry a pack; he would buck, throw himself backwards and roll until we gave up the effort in despair. Nor did he like anybody to touch him but myself. With me, however, not only was he perfectly free from vice, but absolutely reliable. I was exceedingly sorry to part with him when I left Patagonia, but I left him in good hands.

When the zaino was saddled it was almost half-past four o'clock. The district which lay to the south-east of Lago Buenos Aires was one through which few men, if any, had ever passed, and owing to its proximity to the cordillera, which shielded it from the continuous westerly winds and gales, the bushes of califaté, incensio, and maté negra were dense and often five or six feet in height. The immediate object of my ride was the usual one-meat for food.

Tom and Chichi went with me, and we had not gone far when, passing over a hill, we roused a herd of some dozen guanacos, that came bounding out from the margin of a pond where they had been feeding or lying. The dogs immediately gave chase, Tom leading and characteristically devoting his attention to a yearling, which he soon headed. The rest of the herd dashed away in another direction, and the yearling was pulled down by Tom almost without any help from Chichi. As the kill was so near camp I rode back with news of it, and, leaving one of the peones to butcher and carry back the meat, continued my ride.

It was Chichi's first hunt since her feet had been cured, but it was easy to see that she was a high-spirited little hound, and very manifestly Tom ran better and more pluckily with her than with any of his former mates. I at once resolved that if I could I would lay the dogs on an old buck, if it were only to see whether Tom had at last forgotten that 
stunning kick that he received in the cañadon six hundred miles away.

I therefore returned to follow the herd, amongst which I had remarked a couple of good bucks; but as luck would have it there was no need to ride so far, for at no great distance, as I paused on a ridge to have a look round with my telescope, I perceived a fine old warrior all alone and lying down in the grass beside a pond very similar to that from which I had sprung the herd some time earlier. This guanaco was at least a mile distant, but I saw that by riding under cover of a range of hillocks I could approach within four hundred yards of him. Four hundred yards is, however, a long start for a guanaco buck, and the chances were that unless I could get the dogs nearer he would show them a clean pair of heels. For the moment there was nothing to be done but to make a first approach, which I did under the lee of the friendly line of hillocks, and arrived without difficulty opposite the pond beside which I had seen the guanaco lying.

There I dismounted, tied up the hounds, and crawled over the edge of a hummock to reconnoitre. The buck was still resting with his legs tucked in under him. The sun, though low in the sky, was shining with a bright yellow glow, and through the glass I was able to get an admirable view of the animal. He certainly appeared to be one of the largest and blackest and shaggiest I had met with, in fact just the animal for my purpose, but how to get sufficiently near to him seemed a difficult problem. Next I took stock of his position. He was lying almost opposite the middle of the pond, which, being larger than I had imagined, stretched a couple of hundred yards on either side of him. It seemed, as far as I could judge, to be deep. As to the chances of approach, I now saw some large blocks of glacial detritus which covered the ground that lay between me and the guanaco. My only plan seemed to be to bring the 
hounds up under cover of these-in fact, to manage a stalk, taking the hounds with me! By this means I hoped to get them within one hundred and fifty yards, but in the meantime must leave my horse, for which it would be necessary to return later.

When I reached the dogs, I found that Chichi had gnawed through the cabresto with which I had tied her up, but had fortunately remained near the horse instead of following me. Having led the zaino as far as the cover would permit, I fastened the hide rope to the dogs' collars and commenced my stalk. A crouching position took me to the first and largest rock, but my next objective was a stone not four feet high. Moreover, Tom and Chichi did not understand stalking at all, and as soon as I went down on hands and knees they began to pull away from me. At length, by assuming the historical attitude of the great enemy of mankind, I arrived at the flat stone and found myself within two hundred yards of the buck, which continued to rest entirely undisturbed. I now noticed for the first time that the buck was lying about the centre of a narrow peninsula that jutted out for some little distance into the pond. It, therefore, seemed likely that if the water was as deep as it looked to be the guanaco would be forced to break back, in which case when the chase fairly began the dogs would start within one hundred and fifty yards of him.

After a moment's rest, taken to relieve the cramps in my arms and legs, I slipped both dogs and ran out at the top of my speed towards the guanaco. As he leaped up the dogs saw him and got a splendid start. The buck made off along the lake-shore to the right, and, waiting for no more, I ran for my horse. By the time I had mounted the chase had disappeared, but, galloping to the summit of the incline, I almost ran into the guanaco, who was coming round in a circle. He was travelling at high speed and quite holding his own with Tom. The double he made to evade me 


\section{HUNTING CAMPS.}

brought the dogs within fifty yards of him, and I, pressing my horse, was soon not much behind them. For the first half-mile the ground was so blind with dense scrub that it was all in favour of the buck, but presently leaving this we passed out on to the long, rolling, open pampa, where Tom began to gain, and taking the ground magnificently, closed in on the guanaco, passing him and snapping at his throat. The buck swerved, and Chichi, taking advantage of the movement, seized a flank, throwing the buck off his balance, when Tom went in and caught him by the throat. The guanaco at bay can, however, be a nasty antagonist for hounds, so pulling up I finished the affair with a shot.

After this encounter with the buck Tom improved in every way, eventually gaining some very honourable wounds in a combat with a Magellan wolf. I found that long runs pressed hard on the hounds, as the thorns and stones left them sorefooted. In fact, unless they ran into the guanaco within the first four hundred yards, the chase generally ended in the quarry getting clear away, more especially if the ground was at all steep. In running ostriches the same facts hold good, though with the birds, if the dogs failed to obtain a fair start, they gave up the pursuit of themselves. In many district cavies and foxes were so numerous that unless laid on the hounds took no notice of them.

Once in the neighbourhood of the cordillera I came across an old red wolf (Canis magellanicus) and laid on the dogs. The wolf held his ground, making no attempt to run, and fought so gallantly that I tried to call off the dogs-not without their scars-but before I could make them obey one of the hounds, and also the old wolf, had been so severely hurt that it was too late, and he went down snarling and snapping to the last.

I have always regretted my bad luck with regard to pumas during my time in Patagonia, for, although I frequently heard them in the night about the camp, by day I 
saw but two. One of these, a really magnificent male, with any luck I ought to have killed, but as I dismounted, and before I could disengage my rifle, he galloped off.

I then tried to mount, intending to ride the puma down, but my horse became unmanageable, and before I could quiet him the puma disappeared into some dense scrub, in which I failed to find him again.

Seeing pumas is largely a matter of luck, for the stony hills and bushy country in which they abound offer endless hiding places, of which this distinctly cowardly animal takes full advantage. Again and again I wished I had had half-a-dozen good terriers or mongrels with me, for not one of the hounds or collies would take the trail of a puma, though generally ready enough to bustle a fox out of a thicket. With a pack of suitable dogs I believe excellent sport might be had with pumas, though it is certainly the poorest-spirited of all the great cats. Captain Musters tells how an Indian will attack a puma armed only with his boleadores, and this is still done at the present day, yet, though the puma has no great reputation as a fighter, instances have been known of one turning savage when at bay. They are the constant and inveterate enemies of the Patagonian sheep-farmer, taking a heavy toll from the flocks, and often killing a dozen or more animals in a single raid. They also continually stampede the horses of travellers, a very annoying matter, as I know to my cost. These creatures are very readily tamed, and are often kept as pets till almost full-grown. One settler near Lake Argentino lived alone with two three-quarter grown pumas throughout the winter of Igor in his little single-roomed hut. A strange taste in companionship!

This chapter would not be complete without some mention of the Tehuelche methods of hunting. In former times the fabled Patagonian Indians hunted on foot as do the Onas to-day in Terra del Fuego, but since the introduction of 
the horse from the Auracanian tribes, whose country marches with that of the Tehuelches to the north-west, the latter now always hunt upon horseback.

The Tehuelches are a fine race, with large well-hewn features; their skin is of a reddish brown, but, though they still average six feet in stature, they have noticeably deteriorated in physique from their habit of riding on all occasions and everywhere. A man will not walk a hundred yards, but catches his horse and rides the distance. As far as the upper part of the body is concerned, the breadth of shoulder and great back and arm muscles demand admiration, but their lower limbs are not proportionately strong.

The Tehuelches, unlike most savage tribes, have never adopted the white man's weapons. I never saw an Indian with a firearm, though doubtless an odd revolver may find its way into their guanaco-skin toldos. But for the purposes of the chase they use the boleadores, and some of them are even so conservative as to retain the flint knife of prehistoric times. Boleadores used for the chase of guanaco or ostrich are loaded with balls of solid metal or with stones. Three such missiles, each the size of a tennis ball, one being pear-shaped, to fit the grasp of the hand, are sewn up in raw-hide bags and fastened at the three points of a thong like a Y, two arms of which are some four feet in length, the third longer. Seizing this weapon by the pearshaped ball, which is at the single end of the $Y$, the Indian hunter, going at full gallop, whirls it round his head, letting it fly at the neck or legs of the ostrich or the guanaco that he may be chasing. The impact of the heavy balls will often break the quarry's legs, or at any rate in a few bounds or strides entangle them in such a way as to bring it to the ground.

An organised day's hunt with the Tehuelches is an interesting function. The cacique, or chief, arranges the plans, having first made sure of the neighbourhood of large 
herds of guanaco, which form the staple of the game to be secured. The hunters ride off in couples, each with a led horse in addition to the one he is riding, and accompanied by six or eight gaunt hounds that still betray in some degree their greyhound ancestry. They are mostly too light to be able to pull down a full-grown buck, but against ostriches and young guanaco they are very serviceable.

The hunters form a huge circle, perhaps of some fifty miles, and drive the game inwards, lighting fires on the edge of the circle to mark out their positions and partly to keep the wild animals from breaking back. As the ring of men and fires draw in, the frightened game crowd together in the middle of it. There may be as many as five hundred guanaco or more, many ostriches, and even puma. Captain Musters saw two pumas killed in such a hunt. The guanaco bucks show spirit and stamp and neigh defiance in front of their herds. As soon as the Indians have approached sufficiently near they mount their fresh horses and gallop at full speed upon the startled game. The yells of the hunters, the flying boleadores, the dogs and horses in fierce pursuit after the frenzied animals, all go to make up a scene of extraordinary excitement.

The game breaks in every direction, and the Tehuelches follow for leagues over the wide pampa, their nimble-footed horses covering the most difficult ground-steep, stony slopes, or thickly-bushed levels-with astonishing accuracy. A large quantity of game is killed, much meat is secured, and in addition the feathers of the ostriches. The pelts of young guanaco, tendons, meat, etc., are all collected for their various uses and carried back to the toldos, where a feast takes place amid general rejoicing. 


\section{CHAPTER II.}

HUNTING-DAYS IN THE CORDILLERA OF THE ANDES.

HE cordillera of the Andes is connected with some of

1 my earliest recollections, for my youthful knowledge of geography was supposed to be promoted by drawing from memory presentments of Great Britain and Ireland or one of the continents. The maps on the wall were rolled up, and each small boy was left with a sheet of paper, a black pencil and a red pencil, to produce from his inner consciousness a chart of the land to which his fancy at the moment attracted him. On such occasions I always, unless definitely forbidden, exercised my ingenuity on the South American continent, which gave scope in more ways than one to the play of the imagination. Its contour was familiar, and it was safe to put in one river after another, running from west to east at irregular intervals all down the map; a fishbone of red represented the Andes, and-here came the touch of glamour-tucked away somewhere among their spurs I was invariably particular to mark in two names of old romance, the one Manoa, the other El Dorado. I did not then guess that in years to come I should make a close acquaintance with a part of that continent.

I crossed and recrossed the southern portion of it more than once, and spent many months wandering among the foothills of the Patagonian cordillera, from Lake Buenos Aires in the north to Lake Argentino in the south, generally on horseback, but sometimes penetrating deeper into 
the heart of the mighty range by boat. The lower spurs of the Andes and the levels between them are rich in game, and all through the wide and virgin land the hunter may ride sheltered from the incessant wind which torments the pampas, while during the early autumn one blue and golden day succeeds another and life is refreshing and delightful.

In the shadow of the Andes there are still vast spaces between the towering peaks unvisited and unseen by human eyes. There still remain blanks on the maps that science has not as yet filled in, for few prospectors have touched even the fringe of this region, and the Tehuelche Indians, who are born and live, migrate, hunt, and die within sight of the white summits, can never be persuaded to venture within the limits of the great forests which cling about the feet of the cordillera, for the reason that they believe that the Gualicho, the Spirit of Evil, has his dwelling among the mountains, and no reward of meat or skins or shelter can tempt them to brave his anger.

Another reason for the unbroken solitude of the cordillera is undoubtedly the fact that the forests are singularly devoid of life. As one passes through them the usual sounds to be heard are the purely woodland sounds of falling trees, the rustling of leaves, the snap of a twig, but few calls of birds or cries of wild animals-in fact, signs of organic life grow fewer and fewer the further one advances into their recesses.

But about the foothills and among the thousand gullies and cañadones that run up towards the high bulk of the range game abounds. Round the shores of Lake Argentino, for example, just south of lat. $50^{\circ}$, there exists a plenitude of the larger Patagonian animals. There the distribution of the species overlaps. Guanaco in great herds came down from the tableland near the Manantial Peak, and in a single day's ride I saw sixty-one ostriches (Rhea darwinii). Con- 
siderable numbers of wild cattle roam in the forests of Mount Frias; guemal, the beautiful deer peculiar to the Andes, are to be found in the same district, while among the rocks a quantity of pumas and Magellan wolves make their lairs. To the north and west stretch enormous areas, through which great herds of game wander.

I gained my first view of the Patagonian Andes across the rough waters of Lake Buenos Aires. I had ridden six hundred miles over the pampas, looking forward to the time when I should at last come to the eastern limit of the guemal deer, of which, so far as I know, there were at that time but two specimens in England, both presented by the Argentine Government to the British Museum.

The huemul or guemal is the sole representative of the deer tribe in southern Patagonia, and it inhabits the entire range of the Andes. Naturalists have placed guemal in two main divisions, the Peruvian and the Patagonian. The few Peruvian specimens which I have seen are inferior to their cousins of the south, being smaller and less symmetrical. The Patagonian deer stands some 36 or 38 inches at the shoulder, and weighs, I should judge, though I never had the opportunity of putting an animal in the scales, some I6o lbs. The horns in the British Museum are poor, and I had very great hopes of being able to secure some finer specimens.

Early in my travels I had been told that the guemal (I have preferred this form of the word as it more nearly approaches to the name as locally spoken) extended in its range to the Atlantic, and some few animals were said to haunt the highlands near the outlet of the Rio Deseado. But as far as my own experience goes I am inclined to believe that the guemal does not stray far from the immediate neighbourhood of the Andes.

In Patagonia itself very little was known of this animal ; in fact, for a long time I met no single individual there 
who had shot one, though among my gauchos, a Welshman named Jones had once caught sight of a buck running along a spur of the mountains near the colony of "The r6th October," a settlement lying to the north-west of the country, some seven hundred miles north of Lake Buenos Aires.

The desire to kill something is, in the hackneyed phrase, the dominant aim of an Englishman's life, but when the creature he wishes to kill has rarely been obtained by any other man the desire increases in strength. Give him, further, months of anticipation, and then three weeks of fruitless hunting, and his eagerness will probably grow out of all proportion to the end in view. Yet, surely, it is this very lack of proportion that lends to sport its powerful dominion over its votaries, who, though probably in the main reasonable beings, become so much in earnest while in pursuit that they have at such times only room for the single idea. Such was the state of mind at which I had arrived in the early days of that December.

I had tried by every means in my power to persuade the Indian guide, who was with us at that period, to remain and hunt with me in the foothills, but, though he was willing to accompany me along the shores of the lake, nothing could induce him to venture into even the outermost ring of the mountains. Following his directions, however, I spent a number of days riding through all the likely defiles which sweep from the ridges to the level of Lake Buenos Aires. I had shot several guanaco and a couple of ostriches, and had patrolled the full length of the eastern lake-shore, without discovering so much as the track of a guemal, although the Indian, who had in the interval taken his departure, had pointed out this particular area as the place where from time to time his tribesmen had killed deer.

Apart from its value as a natural history specimen, the meat of a deer would have been very welcome in camp, 
for game at that time happened to be very scarce on the northern shores of the lake, so much so, in fact, that after several days' hunting, which resulted in a total bag of two upland geese, food was at so low an ebb with us that we were reduced to eating a horse we were obliged to shoot. As birds were few and far between on that arid strip of country, I did not carry a shot-gun, but had to deal with those I saw to the best of my power with a rifle. In this way I shot ducks, swans, geese, and ibis. I had met with an accident that prevented my getting about as readily as usual, but as soon as I could travel I rode on the back trail as far as the River Fenix, near to which I had seen some game, and there I found and stalked a single guanaco. The death of this old buck, besides being most opportune from the commissariat point of view, seemed to mark the turning point of my ill-luck in hunting, for on the next day I shot another guanaco close to camp, and later in the afternoon found for the first time the tracks of a guemal in a gulley near the lake, but failed to catch a sight of the deer itself.

About a week after one of my men observed a guemal buck and some does while making camp near Mount Piramide, but crossing to windward they made off. Near this mountain, during the previous year, my friend Mr. Waag, of the Argentine Boundary Commission, had shot several guemal. I was therefore rather disappointed at my vain search, but thought it not unlikely that the fact of being hunted by Mr. Waag's party had driven the deer away from that particular spot. I hunted, riding perseveringly over the ground pointed out by the Indian, for nearly a whole month without success before I discovered a district where they were plentiful ; this was a high strip of tableland between the rivers de Los Antiguos and Jeinemeni, which flow into Lake Buenos Aires from the southern mountains.

To reach these mountains entailed a sixty miles' ride, 
which I undertook with one of my men, and passing round the great lake we came, on the second day, to the Rio de Los Antiguos, and turned along its bank into a valley which seemed to run between frowning cliffs into the cordillera. After following the valley for some distance we forded to the western bank of the river and pitched camp, on a spot clear of thicket and close to a forest that looked very green to my eyes after our long journey over the pampas.

That same evening, close to the camp, I found the tracks of a guemal that had come down to drink at the river. It had been stalked and attacked by a puma and her cub, but had managed to get away into the woods, where I was unable to follow the trail, and so did not see how the unequal contest ended.

Next morning we pushed on up the valley. From the top of the cliffs a tableland stretched westwards to the valley of the Jeinemeni, and I fancied this strip of high country shouid be a likely hunting ground. And in fact, as I was riding the following afternoon along the top of the barranca, a young guemal buck suddenly sprang out from some rocks in front of me. As I was the first human being he had ever seen, he halted in curiosity to have a good look. His pretty attitude, no less than his confidence, made it hard for me to shoot, and had we not been in urgent need of meat I should have let him go, as his horns were but four or five inches long. However, Nemesis followed at once, for, though I hid the meat while I went to fetch my man and the other horses, the condors took such full toll of the deer that we had a very scanty meal after all. Before leaving this tableland I shot another young buck in the failing light of a cold evening.

My next chance-and my first at a warrantable buck -came at a most inopportune moment. The river had risen during our stay on the tableland, its shallow current 
had changed to a yellow, tumbling torrent, which carried down with it from the heights trunks of trees and other débris.

After a good deal of manœuvring and a closer acquaintance than I desired with the snow-fed water, we had crossed over and were not more than fifty yards from the river bank, when two guemal does, led by a beautiful buck with horns far larger than any I had seen in the museums, broke out of a thicket of wild currant bushes and stood for a moment at gaze. Having neither my rifle nor my gun owing to an accident, I seized my companion's Colt, and as the buck sprang away I fired at his shoulder. The buck disappeared, and my man remarked that the Colt did not shoot very straight, a fact I happened to be well aware of, as I had previously tried it at a target with the poorest of results.

But on this occasion I felt sure that I had heard the bullet strike, and, following, I soon picked up a blood trail, which brought me at length to the animal lying dead in a currant brake. The bullet had entered his neck, and as I had aimed at the shoulder I was very lucky to get him. The horns, to which shreds of velvet still hung, measured ten and a quarter inches, considerably more than those of the best museum specimen.

A few days later, as I was riding beside the river on my way back to camp, I chanced to look up and saw far above me, at the head of a huge rift in the cliff, a guemal buck and a doe. He was standing overlooking the valley, and between me and him lay several hundred yards covered with rocky fragments. I dismounted and focussed him with my telescope, and, judging that he had a fine head, I began to stalk him. As I had only shot a few deer I was resolved not to lose this one, and consequently I moved with great care, worming my way among the boulders. At a distance of about four hundred yards I again used the 
telescope, and saw that the head carried an extra point and was far the finest I had seen. But soon after I recommenced my stalking the buck grew suspicious, and without warning bounded away.

Surprised at this-for hitherto the guemal I had shot had proved so tame as to afford little sport-I made my way back into the valley, and, riding round the bluff, I found a gradient that my horse could climb, and was soon galloping across the tableland, over the edge of which the deer had disappeared. I had not gone far when I again sighted the buck. He was standing out in the centre of a grassy space watching me. As there was no cover at all, I began to ride round him, narrowing the circle until I got within two hundred yards, when I dismounted. As I did so he ran back a few yards and stopped when I shot him.

From my later experience of these deer I am convinced that, either afoot or on horseback, I could have ventured to much closer quarters, though if I had continued my first line of stalk and, trying to keep myself hidden, had crawled into view over the edge of the cliff, he would probably have made off directly he caught a glimpse of me. In fact, I believe that in the first instance he mistook me for a puma, the only animal, except the Magellan fox or wolf, which the guemal hàs to fear. This would explain his flight. Indeed, at all times I found guemal more easy to approach if I walked towards them in an upright position than if I attempted to get to close quarters by crawling.

From the point of view of sport the guemal were something of a disappointment after the long and difficult journey it was necessary to make before reaching them, and, though I shot a few for meat and for specimens, I doubt if the obtaining of some record heads was ever attended with less keenness : but though they will stand to stare with curiosity at a human being, once they get the wind they are wild enough; also in woodland and cover they are not readily 
outwitted. Above all, the world now contains few species or sub-species of deer, of which no more than a couple of specimens are attainable for purposes of study, and a very special interest on that account pertained to the pursuit of these deer.

Owing to the fact that the heads available for study of the guemal carried but two points on each horn, it has been supposed that the single fork of the antlers was characteristic of this species, but such is not the case. Of the specimens which I obtained, two carry an extra point. In one pair of antlers no less than two extra points are more than indicated, and as these seemed to belong to a very old buck, I am led to believe this animal, when his horns were at their best, carried six developed points, and I have heard on good evidence of an eight-point head.

I was unable to gather any reliable information as to when the guemal drop their horns, and I can only give the facts of my own observations-that the horns are in velvet in November; that they become clear of it, especially in the case of old bucks, early in December; and that as late as the I2th of May the bucks are still carrying their antlers.

One feature that can hardly fail to strike any traveller about the Andean foothills, as indeed upon the pampas and throughout the whole of Patagonia, is the extraordinary number of birds and animals of prey that exist in the country. All about the lakes and in the edges of the forest uncounted pumas and Magellan wolves, as well as myriads - no other word describes it-of hoary dogs, have their abode and seek their sustenance. The air, too, furnishes a corresponding contingent of flesh and carrion eaters, coranchos, chimangos, and condors. Short of the Arctic circle, the struggle for life is probably a harder one in Patagonia than in almost any other region of the world. Not once or twice, but again and again, when I killed wild fowl, my prize was 
snatched from me by some rapacious bird. In Scotland I have occasionally lost dead and wounded duck owing to the attentions of hoodie crows, but never have I had to hold with the gun or rifle what I had secured by the gun or rifle to the same extent as in Patagonia. The idea of a cache in Patagonia, using the ordinary northern acceptance of that term, is absurd. Except under a roof nothing is safe, and even under a roof, if provisions be left for long, the foxes will dig their way in and devour them. Whatever you kill in an exposed or open position is reduced to bare bones within a couple of hours.

The condor is the largest of the New World vultures. They stand well over three feet in height, and are said to measure in some few cases fifteen feet across the outspread wings. I only shot two or three-as the slaughter seemed useless - and the largest of these, an unusually fine specimen, measured well over ten feet fully stretched from tip to tip of its wings, while a young bird I shot off Hellgate Cliffs and measured carefully spread nine feet three inches.

Altinough the predatory greed of the birds was a great nuisance when we wished to preserve game for our own food, I nevertheless passed many interesting hours in watching them. I had read a great deal concerning the habits of vultures and the marvellous speed with which they appear about a carcase, as well as various speculations as to the particular sense which enables them to discover it. I made one or two experiments with a view to gaining light on this question as far as the condor is concerned; but before I began these I had had many times to face the task of keeping the condor off game that I had shot in the open country, and I found that to succeed in this was quite impossible unless I remained beside the dead animal. To tie handkerchiefs and rags to flutter and float above the body had no scaring effect, for the birds disregarded them 
altogether, and to drag the low bush of the pampas over the kill was equally futile.

On the other hand, a guemal and a wild bull, which I shot at different times in thick wood, though partially eaten by both pumas and foxes, did not appear to have attracted the notice of the condors. These instances, and one or two others of a similar kind, seem to show that the condor finds its food purely by eye. One day in the vicinity of Lake Buenos Aires I shot a young guanaco. At the moment the animal fell, and for five minutes afterwards there was not a condor in sight in any quarter of the heavens. Having gralloched the animal and taken a part of the meat, I retired to the shelter of some rocks which lay about a hundred and fifty yards from the carcase. I had hardly reached them when a condor swept over and, after circling once, pitched beside the kill. This bird had not begun to peck when he was joined by two more, and in six minutes by my watch no less than thirty-eight of the great carrioneaters had arrived on the scene. They made little noise as they pecked and tore, but when I rose from my hidingplace-where, by the way, I certainly was not invisible to them-and ran towards them, they, or some of them, gave vent to a kind of snuffling groan; I cannot describe it more accurately than in those words. Although the birds gorge when opportunity offers to such an extent that they can only with difficulty rise from the ground, on this occasion such of the guanaco meat as I had left gave but a snack to each, and they all flew off with a great beating of wings.

On another day, having again shot a guanaco, I sat down in the open on a stone not more than fifty yards from it. Soon the condors began to appear, as well as some coranchos. The latter perched on the bushes at a distance, and the condors did not alight until I had gone some forty or fifty yards further off, when at last one bolder 
than the rest settled and began to pluck out the guanaco's eyes.

It has since been a matter of regret to me that I did not try to get some condors' eggs, but it was rather late in the season, and, though I saw many of their breedingplaces on the high cliffs round the Andean lakes, the young birds were hatched by that time, for it was already December when I reached the mountains among the cliffs of which they nest.

There can be no doubt about the fact that condors do attack living game, though it is probable that they choose the very young or weak animals as their prey. I can recall an instance that I witnessed near Lake Argentino. I was riding down a rugged cleft in the deep cañadon of a river valley on the eastern side of the lake when I saw on a ledge ahead of me a guanaco struggling to rise from its knees. The poor creature was too weak to do so in spite of its furious efforts. Two large condors were hovering close above it. As I galloped up the guanaco fell over on its side, and one of the birds instantly lit close by and pecked at it. I rode up in less than a minute and the condor rose at once, but in that moment it had torn out both the guanaco's eyes. When, after putting it out of its pain, I examined the animal, I found that it was suffering from scab and was so emaciated that it must have been on the point of death when the condor attacked it.

Nothing more ghastly can be imagined than the fate of the solitary rider who meets with an accident in that region; such an incident forms the subject of a powerful and gruesome picture which hangs in the Natural History Museum at La Plata. In this picture a gaucho has fallen from his horse and lies helpless on the ground, while the condors and other birds of prey are sitting round him or wheeling in the air above his head. It represents, I am afraid, a tragedy which the pampas have often witnessed. 
Certainly of all game in Patagonia the wild cattle in their favourite habitat, the thick forests of the southern cordillera, afford the best sport and are the most difficult to bring to bag, if such an expression may be used of a quarry weighing close upon $2,000 \mathrm{lbs}$. These animals are said to have bred wild since their ancestors escaped from the early Spanish settlements on the Valdez Peninsula to the grassy hollows and forested spurs of the cordillera, since when fresh blood has no doubt been constantly brought in by truants from the estancias on the coast.

The wild cattle mostly frequent the forests about the Andean Lakes, and those that have been free for generations present a fine appearance, having lost the smooth aspect of domestication and reverted to the shaggy hair, lean bodies, and longer horns that mark the wild strain. In the daytime they keep much to the thickest forests, wandering to their edges morning and evening and feeding to a great extent by night. As to drinking-places, their range in the woodland is well supplied with streams.

If the wild bull only possessed a better trophy, few beasts would stand higher in the category of dangerous game, for he passes his life amidst surroundings of great natural beauty, among the forests and peaks on the frontiers of the cordillera, though sometimes the herds push right up to the snowline. Added to the fact that they occupy very difficult country, experience has made them extraordinarily wary. If attacked or wounded they invariably charge, and are agile enough to be exceedingly dangerous antagonists.

All the hills and high ground about Lake Argentino are scored by the paths and trails made by the wild herds, many of them leading, over the open summits. During the spring and summer the cattle remain upon the heights.

In autumn and winter, driven downwards by the snow, they descend to the lower forests and wander out upon 
the pampas, at which season they are much followed and persecuted by wandering gauchos, if any such happen to be in the vicinity, who catch the cows and calves with their lassoes and "lead them into captivity, captive." This state of warfare with man has developed both acuteness and extreme caution in the cattle, so that a whole herd will disappear at once on the slightest alarm and seek a fresh ground. Again and again I have been very near to herds in the blinding cover of the forests, but each time only to find by their tracks that they had eluded me. Yet one is apt to come upon old bulls, either singly or in twos and threes, when still-hunting. In this case the intruder upon their seclusion is more than likely to be charged at close quarters.

With the exception of man the bulls have of course no enemy of whom they need take account, though a certain number of calves are probably killed by pumas. In fact, when any herd, wild or tame, comes upon the track of one of these animals they will often follow it lowing for a certain distance.

In an unfenced and unpopulated country like Patagonia numbers of cattle escape and run wild for months at a time. These for the most part make towards the mountains, and gauchos have often remarked to me that when they have come across strayed cattle on the plains they were nearly always heading for the west. This may be accounted for, as the animals would naturally travel up against the prevailing winds, and so in time they reach the rampart of the cordillera, where they find shelter and good food and can foregather with their wild-bred kindred.

At one time I believe the Falkland Islands were famous for wild-cattle shooting, the animals being driven by gauchos to posted guns. In those good days British naval officers were sure of exciting and interesting experiences when they visited the realms of the "King of the Penguins," as the 
Governor of the Falklands used to be called from the vast colonies of those birds which inhabited his regency. But that time is past, and the Falklands are now given over to mild flocks of sheep.

One of my first experiences with wild cattle occurred in the neighbourhood of Lake Buenos Aires, when I and my Welsh gaucho, Humphrey Jones, came in the early morning upon the track of a big bull. On his trail we rode hour after hour, and though at one time all signs proved that we were very close to him, he finally led us into a stony and arid belt of country where we could no longer hold the track. In spite of losing him, the experience was interesting in that it showed the pace at which a bull will sometimes travel, for at the start we were not above an hour behind him, and we followed at a good rate. No doubt in some of our wheeling and turning the bull got the wind of us, which hastened him on his journey to the refuge of the distant cordillera.

I was perhaps unfortunate in that I was so often near the herds without obtaining a shot, as once in the gloaming I saw a herd containing some magnificent old bulls descend the rugged side of Mount Buenos Aires to drink in Lake Argentino. A deep rift separated me from them, and by the time I had made my way round it was too dark to shoot, though I could hear the great brutes moving about in the water just beneath me. Of course, on occasions considerable numbers of the true wild cattle have been killed or captured in a single day, but this has always taken place on the pampas; in the cordillera such an occurrence would not be possible.

After a shot it was an almost hopeless task to attempt to come again within range of the same herd that day, and under cover of the following night they usually left the mountain on which they had been disturbed. During nineteen days of hunting wild cattle near Lake Argentino, 
though I was continually finding the tracks and beds of bulls, I only had shots at two. This was partly owing, however, to my refusal of a few other chances, for I sighted the animals in such difficult positions that, as I was carrying only a .275 Mauser, I was afraid of only wounding without enough probability of a kill.

One day when riding down to the low forest-where I had seen a guanaco standing actually in the edge of the trees-I found the tracks of a herd numbering a dozen or more, and I followed them for several hours. I was just thinking of taking a few minutes' rest, when I heard a stick crack on my left front, as an outlying cow gave the alarm to her companions. Running over the rise, I was in time to see a bull as he dashed away. I got in a stern shot which checked him, and the second barrel of the Paradox behind the shoulder brought him down; but even then it needed a third bullet to finish the business.

On another occasion I spied three large animals from a great distance. Two of them were lying down, and I could only see the quarters of the third, whose head and fore part were hidden by a bush. The cattle were several hundred feet above me and considerably over a mile away. In order to approach them without getting to windward, it was requisite to make a very wide circuit and to come down upon them from above, where the ground, through the telescope, appeared to be covered with huge boulders of basalt, that promised adequate cover for the stalk. The climb to the top of the mountain was long and hard. I made my way up the steep gully of a narrow torrent, crossing many of its ice-cold tributaries, until at length I reached the crest of the peak, and was rewarded by a view of the most magnificent spread of scenery. When heated in the chase the hunter is not always actively conscious of the beauty of his environment, as he has time and inclination to be during the many long pauses and waits of stalking, 
yet that the beauty of environment appeals to some subconscious self is certain, for scene after scene not sensibly noticed at the moment of seeing remains clearly etched on the memory. The Patagonian Andes may well be described as " unspeakably grand and terrible," for such is the impression they usually make upon the mind; but on the day I write of the sun was shining brilliantly and had changed the whole aspect of the scene. For once the formidable summits, 8,000 or 9,000 feet high, crowned with snow and clothed about their flanks and spurs with dense black forest-lands, were lit and softened. In the sky there was not a cloud, and far below me the lake, so often stormtossed, shone like a pool of fathomless blue.

Although it had been still enough in the valleys, a pretty strong wind was blowing on the heights. A bold escarpment hid me completely from the bulls, and it was not until I was opposite a rock which I had marked as being on a line with them that I peered over. At first I could discover no sign of the wild cattle, but moving cautiously to another coign of vantage I saw one, a great brindled bull, walk slowly into view along a game-track. He was soon followed by a second bull, if anything a larger animal ; this latter was an overo, as the Spaniards call a piebald of black and white. The third was not visible. The bulls were about four hundred yards away, but between me and them was a wide outcrop of glacial detritus, among which I crawled towards a boulder, within a hundred yards of which it seemed to me likely the bulls would pass. I was hardly half way to the boulder, when a pair of horns suddenly came in sight. These belonged to an animal lying down lower on the hillside, and which had hitherto been hidden by the rocks. At a hurried glance I imagined it must be the first of the two bulls I was stalking, as the colour was brindled. He was quite unaware of my presence, and remained so while I crawled forward with great care to the next point I had selected. 
When I reached it I found I was within eighty yards of him, as he lay sleepily only a few feet from the game-track. I was beautifully placed for a shot, but a second look told me that this was not the great brindled beast I had first seen, but the third animal, which was nothing like as large and with far inferior horns. I was quite contented, nevertheless, as I believed it to be only a matter of time, for I knew his companions could not be far away, but were probably approaching up the game-track behind him and just out of sight over the edge of the ridge. I waited for several minutes in expectation, but as they failed to appear I began to fear that they had turned off the main track. There was nothing for me to do but to remain where I was, as I could not advance without being discovered by the young bull in front, and to return on my tracks did not seem to promise any better chance of success.

I could have shot the small bull easily, but I had set my heart on the two patriarchs, whose mighty horns I resolved to have or none. For more than an hour the troublesome four-year-old kept his position and forced me to keep mine, and when he did at last rise he left the game-path and made straight towards me. Every moment as he moved I expected to see the horns of the other bulls rise over the ridge, but he lumbered on slowly till he was within forty yards of me, when suddenly his whole aspect changed-he broke into an unwieldy trot which almost immediately became a gallop. At the same time there was a crashing above me, and, looking up, I saw a herd of fifteen or more cattle tearing along the mountainside till they disappeared down a gully. This herd must have fed right up to windward of me, and among them probably the two big bulls, for, from an examination of the tracks, I found these two had branched off the main game-trail and joined the herd, of whose presence I remained ignorant until too late. At one time the whole herd, with the bulls, in travelling upwards, had passed 
within a hundred paces of my hiding-place, and only the presence of the small bull had stood between me and the best of chances. However, I was destined to kill a good bull from that same herd a few days later, when I once more got within range of them, and this time secured a large red bull, the only one at which I could get a clear shot.

On the whole the luck which is said to sway " to-day with the hunter, to-morrow with the hunted," kept well on the opposite side during all the time that I hunted wild cattle, for although I had not the chagrin of actually missing any animal I shot at, yet several times when I had climbed and crawled within range of the outlying members of a herd these turned out to be cows or small animals not worth shooting. If I had been given even an ordinary degree of luck I ought to have obtained at least half-a-dozen magnificent bulls. As it was I had to be content with two good ones, but my chief regret lies in the fact that it is unlikely I shall ever have the chance of a return match with them, for the sport is nothing less than first class, and the vigorous days spent on the mountains possess a charm that makes one long to experience it again. When hunting wild cattle in this neighbourhood, I saw a number of guemal, all much wilder and more difficult of access than their less experienced fellows about Lake Buenos Aires; but, though some of these had good heads, I was often obliged to pass them by, as the report of a rifle would have frightened away the greater game.

While going back to camp one evening I saw an animal sneaking along the shore of the lake, which I soon made out to be a Magellan wolf or fox. As it was moving rapidly I was very much surprised when a long shot hit it. The wolf snapped at the wound and vanished into some brush. I followed it, and as I came close it dragged itself out and ran at me. Before I could fire its teeth were fixed in my putties, 
when I killed it with a kick. Although a small animal, measuring but three feet four to six inches from the teeth to the tip of the tail, these red wolves are most courageous; they seem to have no fear whatever of man. In another district one of them ate the leather slings of my rifle from the tent in which I was sleeping, and next morning, instead of making off, remained under a bush in the camp, where I shot it. On a third occasion that I remember I had killed an ibis, and as I walked up a wolf ran out and seized the bird right in front of me. When I came close it dropped the ibis, but stood growling and snarling over it, disputing possession until I was within a yard or two, when it ran to attack me, only, of course, to receive the second barrel of my gun. The immediate vicinity of the cordillera appears to be the habitat of these Magellan wolves, for I never met with them elsewhere.

In fact, the best sport in Patagonia is to be obtained in the neighbourhood of the Andes, for about their lower spurs and foothills, as well as upon the country immediately below, where a chain of lakes lies linked for hundreds of miles, all the larger animals are to be found. Guanaco and ostrich abound on the lower slopes and the adjacent levels, while higher in the mountain region guemal and wild cattle have their home. Pumas exist everywhere, but are more numerous in the rocky escarpments of the lower hills. These five species make up the hunter's list in Patagonia, which in this, as in all else, is chary of her gifts to man. Once an Indian was asked why the Good Spirit (Who among the Tehuelches is nameless), when He created the guanaco and the guemal to feed His people, did not add other and larger animals to His benefits. The Indian answered: "For that do not accuse the Good Spirit, for when He dwelt in the cave and made the guanaco for our use, the Gualicho, the Spirit of Evil, made the puma ; when He made paahi (the cavy) the Gualicho made the fox. So the Good Spirit ceased to 
fashion animals for His children, lest worse should come of it."

As practically nothing is known of the various parts of Patagonia and the methods of travel necessary to reach the various hunting grounds, it is possible that a few words on localities and equipment may not be out of place.

As I have said, the larger game of the country are chiefly to be found in the neighbourhood of the Andes. To reach the cordillera a long journey across the pampas must first be made, and for this a troop of horses is required. Horses may be bought at the various estancias along the coast, the price varying from forty dollars Argentine in the north to eighty dollars in the south-in English money fifty to a hundred shillings. Trained pack-horses are rare; such as one buys are usually very troublesome and have to be taught their business. A light waggon is infinitely preferable; but light waggons are unknown in Patagonia, and the clumsy vehicles which do duty there are not altogether suitable for rough travel, although they are used in default of better. They are apt to break down, or rather literally break up beyond hope of repair, at embarrassing moments when in some centre of desolation. It would be quite worth while for an intending traveller to ship a buck-board down the coast, as it would prove of great value in cross-country locomotion.

Pack-saddles and horse-gear should be taken from Buenos Aires, and Messrs. Krabbé and Higgins in that city are first-class agents, who spare no trouble in making arrangements, and from them absolutely reliable information on all points can be obtained. This firm will act as bankers, and in fact their aid is in every way invaluable.

The Andes may be reached by several routes along the Atlantic coast, the journey varying in length from six hundred down to a hundred and fifty miles, according to the place of departure chosen. I myself crossed the pampas 
four times-first from Puerto Madryn to Lake Buenos Aires, returning by the River Chico to Santa Cruz, and the second time by following the River Santa Cruz to Lake Argentino and coming back across country to Gallegos. The average rate of travel should work out at about fifteen miles a day.

A waggon-driver and two gauchos can look after thirty horses, and this number should be ample for four men on an extended trip. In buying horses it is very important to secure a tropilla well accustomed to their bell-mare, for all over the country it is the common usage to hobble the mare at night, when the horses of her tropilla remain round her instead of straying. I had but two mares with sixty horses, and as soon as they became used to the mares they never wandered. On the other hand, if the traveller takes four or five mares, to each of which half-a-dozen horses are trained, not only are the chances of losing a tropilla infinitely multiplied, but the finding of a smaller number of horses is a matter of correspondingly greater difficulty. No pains should therefore be spared in selecting well-trained troops.

As to men, gauchos are to be found in most of the settlements, but here again great care should be taken to secure the services of reliable men through well-known estancieros or with the help of the British consul at Punta Arenas. Wages run from forty to eighty dollars a month. There are, as a matter of course, always a number of unsatisfactory gauchos knocking about the coast towns, who must be rigorously avoided.

Most of my provisions I bought through Messrs. Krabbé and Higgins, but simple necessaries can be obtained in Trelew, Santa Cruz, or Gallegos, and by arrangement at some of the coast estancias. Luxuries are high priced, but yerba, flour, farina, and tinned goods can be had at fairly moderate rates, though it is wiser to take out tea from England. Many of the ports are free, and it is well to choose one of these and thus avoid the customs. A letter from the 
Government at Buenos Aires is very valuable. When I was in Patagonia no licence to carry arms or to kill game was required. Laws with regard to the branding of horses are exceedingly strict and are administered by comisarios, who are to be met with at every tiny settlement. These officials have it in their power to give much annoyance, and one cannot be too careful about one's papers.

An expedition may reasonably expect to find game for the pot over the greater part of the country, though there are certain areas on the pampas from which the Indians have driven every four-footed thing, yet even in these districts a shot-gun can keep a small party adequately if not well fed. If, however, a journey is made deep into the cordillera, sufficient food must be taken for the entire trip.

As to the best localities, the southern coasts of Lake Buenos Aires and the valley of the River de Los Antiguos are full of guemal, as I believe are most of the almost untrodden valleys round the majority of the Andean lakes. There are also some wild cattle on this country, but once the cordillera is reached a herd may be found anywhere, or a great stretch of country may prove entirely barren. The ground on which I hunted wild cattle near Lake Argentino is now taken up by settlers, and is likely to be quite shot out.

Although, except on one occasion, I always used a .275 Mauser, this rifle is undoubtedly unsatisfactory for wild cattle, and, as I have said, the lightness of the bullet prevented me from firing at several bulls which I certainly could have secured with a heavier weapon, and in the thick timber the use of the Mauser is foolhardy. For the pampas any of the small bores are perfect-in fact, two such and a good Paradox form an excellent battery. It is well to take a spare rifle, as the country is exceedingly rough, and a fall from one's horse on the stony or treacherous ground over which most of the galloping is done may badly damage a rifle. 
The climate is dry and good, and ordinary English shooting clothes make adequate wear, but the tweed should be of a harsh texture or of moleskin or elephant cord, as otherwise it will be torn to pieces in a few days, for Patagonia is a land of thorns. Boots with nails or, for stalking, with thick red rubber soles are the best footgear.

On the pampas tent poles and pegs must be carried, as these areas are bare of wood, and the tent-which it is rarely necessary to erect as the weather is so dry-must not be too high, since the winds are often tremendous, and pegs do not hold well in the loose arid soil. But all over the country it is possible to collect enough brush to boil a kettle, and south of latitude $50^{\circ}$ water is generally to be found without trouble. In the north more care is needed, as there are many dry regions in which the pools lie so far apart as to constitute a very real danger. 


\section{CHAPTER III.}

\section{ON THE LABRADOR.}

T must be acknowledged that there is something extraordinarily attractive about a hunting-ground that is still virgin, especially when it holds out a prospect of illimitable square miles of country and endless possibilities of anticipation, even if these latter never materialise.

It was with this most elusive charm about its practically untrodden interior that I set out for the Labrador peninsula in the early autumn of I903, with the hope of finding out how and where there was a reasonable chance of coming in view of the herds of Barrenland caribou that roam at large through that houseless land.

Mr. J. G. Millais accompanied me to Newfoundland, intending to go on to the Labrador, but on arriving at St. John's we found to our vexation that the Virginia Lake, the Reid Company's steamer, which at the time plied to the further Labrador ports and has since been lost on that coast, had started for the north and was not expected to return for ten days or a fortnight. Upon learning this Millais decided to shoot in Newfoundland and to give up the further trip as it was late in the season and it was necessary for him to be back in England by October. As this was not imperative in my case, I determined to carry out my intention of reaching Labrador, as, though I had small hope of being able to complete any extended trip before the ice closed, I thought that for any subsequent attempt I might 
make some first-hand knowledge would be exceedingly useful.

At that time, I903, there was no recent work written upon the Labrador peninsula, except the admirable reports of Dr. A. P. Low, of the Canadian Survey, and these were concerned chiefiy, indeed almost entirely, with the districts west of the George River, but next to no information regarding the region lying between that river and the east coast seemed obtainable. All things considered, I was convinced that, even in the face of various set-backs, the trip was well worth while. I spent a good deal of time making inquiries among the whalers and about the south side of St. John's Harbour, but the cod-fishers, who had experience of the Labrador, although well acquainted with the sea of those latitudes, and all that therein is, knew singularly little of the vast interior upon the foreshore of which they had passed many a summer. Some told me that they had frequently heard of large numbers of caribou being killed near Davis Inlet in the autumn; I was also assured that it would be useless to take a canoe with me, as the Indians who came out to the east coast to sell their furs were obliged to pack in and out to the George River, owing to the lack of navigable waters. This latter piece of information proved to be incorrect. A map gave no more help, as practically all the country behind the coast-line lay blank or filled in here and there at haphazard with a river or a lake. I received much assistance from my friend Mr. R. G. Rendell, the agent of the Moravian Mission to Labrador; the Reid Newfoundland Company also kindly provided me passage in the Virginia Lake, adding their good wishes for the success of one of the first hunters to leave behind the well-stocked barrens of Newfoundland with a view to going further afield and, probably, faring worse.

For nearly seven months of every year Labrador above 
the 5oth parallel is shut off from the rest of the world by a barrier of ice, its only communication being maintained by a komatik, or dog-sledge, post that arrives about Christmas. During the summer its desolate settlements receive a fortnightly or three-weekly visit from the mail-boat Virginia Lake, the Hudson's Bay steamer The Pelican on summer service to their posts, The Strathcona of the Deep Sea Mission carrying the gallant Grenfell on his errands of mercy, and The Harmony, which brings supplies to the Moravian Mission stations: these, with the cod-fishery fleets, sum up the usual traffic of the open season.

As might be expected, Labrador is one of the most thinly inhabited countries in the world. Its native population consists of a few hundreds of Indians in the far interior and a few groups of Eskimo on the coasts. To these may be added the "livyeres," or "live heres," as the white settlers are called, the factors of the Hudson's Bay Company's posts, and last, but not least, the missionaries of the Moravian Church, a body of men who yield to none in the singleness and nobility of their aims, and-often a very different thing, alas ! - in the adequate methods by which they pursue them. So much for the residents all the year round. In early summer these are increased by the cod fleet from Newfoundland, who at the earliest moment that the weather permits battle north in their schooners and take possession of their little wooden stations which dot the coast from Square Island to Fanny's Harbour. Their season lasts from June to October, and during this period they work as hard as men on a Polar expedition.

The Labrador, thanks to the Moravians and the Deep Sea Mission, with the indefatigable Dr. Grenfell at its head, is a most God-fearing region. At the cod stations they will not even dry fish on a Sunday. On a certain glorious Sunday morning the head of one of these little colonies remarked ruefully, "If to-day had been yesterday, I'd have 


\section{ON THE LABRADOR.}

got every kental dried, and now may be we'll have no sun until we sail "- - an eventuality which would have meant the loss of several hundred dollars; but fortunately on this occasion the sun shone brightly, not only on Monday, but even on Tuesday.

It was already the gth of September when, accompanied by Jack Wells, now one of the best-known Newfoundland guides, but then promoted from a cook to a full-blown guide for the first time, I went aboard the Virginia Lake, sole passengers, and started on a coasting ship's slow passage up the coast. The steamer called at over fifty points before, after two attempts, we finally landed, during a half-gale from the south-east, at Fanny's Harbour.

We had no sooner gone ashore than my medical knowledge was requisitioned for the cook of the fishing-station, whose hand had been poisoned by a cod bone and whose arm was frightfully swollen. As, however, there was a Government doctor on board the Virginia Lake, and the ship would call at Fanny's Harbour on her return trip, my medical skill was only tested to the extent of a poultice and bandaging, which was doubtless a lucky thing for the cook. A couple of days later, as Jack Wells and I were returning from shooting, a loud and dolorous cry was accounted for by the information that the mail-boat doctor was "putting cook to rights."

Fanny's Harbour is an island settlement, and as the "livyere" who carries the mail across to the mainland had, for some unexplained reason, departed on the day previous to the arrival of the Virginia Lake, we were in a sense marooned upon the island, where, however, we added to the provision list by shooting an Arctic hare and a brace of ducks.

The gale held for two days before, weary of waiting, I at length prevailed upon the head of the settlement, Capt. Tom Spracklin, to lend me a trap-boat with a crew to row 
her, and in the black of dawn, after a most glorious display of Aurora Borealis, the "search-lights of God," we set off for Davis Inlet, twenty miles away.

Before leaving St. John's I had arranged with the Reid Company to send the Virginia Lake to call for us at Fanny's Harbour about the I7th or I8th of October. In view of possible contingencies and to secure as much time for hunting as possible, I purchased the trap-boat, and in the event it proved useful.

We started before dawn, as at that hour the wind had died away and the dangerous passage between the twin rocks which guard the entrance to Fanny's Harbour seemed practicable. Soon the settlement was standing behind us, a compact rocky mass against the dawn, as the boat, propelled by six enormous and clumsy oars, crept slowly out from its shadow. To starboard the swell was bursting upon the bases of seven or eight huge icebergs, while upon the port side of our little craft lay the wild coast of Labrador, low and bare until it rose into the massive headland of Cape Harrigan.

Rain commenced to fall at dawn, and about midday it became obvious that we should not be able to make Davis Inlet before dark, and, as no one aboard had a pilot's knowledge of any portion of the coast save the rocks and reefs of Fanny's Harbour, the helm was perforce put over and we headed for Jack Lane's Bay, a deep creek upwards of a dozen miles long, on the north side of which, I was told, there dwelt an old trapper named Sam Broomfield, who had killed some deer the previous year.

At first upon both sides of the inlet the shores were flat and treeless, but as mile joined mile in our wake, patches of hardy conifers became more and more frequent. Several flocks of yellow-shanks, locally known as " twilligs," haunted these flat shores in some numbers, and one or two that flew over the boat were saluted with a Paradox shot-gun. Ulti- 
mately three twilligs and a red-breasted merganser made up the bag. Just before we came in sight of Broomfield's house an exceedingly wild seal, of the species known as harbour seal, or bay seal, an animal identical with our common seal, Phoca vitulina, showed at a distance of about three hundred yards, but having evidently had some former experience of boats, it dived immediately, only to reappear some ten minutes later in mid-estuary.

As a matter of fact, seals are wilder about Labrador than in any waters I have visited, excepting only the Froien off the coast of Norway, a group of bare islands almost cut by the Arctic circle. Of course, the reason of the wariness of the seals in Labrador fiords is not far to seek. The skin, flesh, and blubber form very important assets in the lives of the shore-dwellers. Boots made of sealskin are the universal foot-gear, and fetch about $\$$ I.5O to $\$ 2$ a pair. I afterwards found that in the making of these boots, and indeed in all Arctic needlework, Mrs. Sam Broomfield stood unrivalled even by the Eskimo. She uses the pelt of the common seal for the legs and that of the square-flipper for the soles, while she ornaments the tops with a fringe of ring-seal. Boots and moccasins made by her are sought after far and wide. While I was up country she made me a camera case and a cartridge bag of sealskin, both of which show absolutely no sign of wear, even after the many hard trips they have undergone.

However, we have travelled ahead of the boat, which soon beached beneath the cabin. Our landing was attended by a dozen huskies, animals which recent fiction has glorified beyond their deserts. These dogs, led by a powerful animal called Buller, watched us disembark with their bright eyes. Fiction has told how the moment a husky, vanquished in fight, loses its legs its team-mates fall upon and tear it to pieces, but fiction has not added that a child, or even at night in some instances a strange adult, must 
also keep his feet to secure safety from a similar fate. A few months before our visit a child at Cartwright, one of the Hudson's Bay posts, slipped upon a wooden jetty and fell amongst the huskies. There were upwards of fifty bites upon her before her mother, who showed the highest courage, succeeded in driving the brutes off. During the daytime the husky is fairly amenable to the well-aimed stone, but at night, or under stress of temptation, the savage wolf nature breaks out at once. I can still remember an anxious pilgrimage $I$ made in the starshine to fetch a shirt I had left to dry on the bushes, during which I was accompanied by Buller and his fellows, all treading delicately.

In the summer time the ordinary Labrador livyere does not trouble himself overmuch with the problem of dog food. If he happens to catch a fish unfit for human consumption he carries it home for the dogs; if not, the animals are left unfed and support themselves by theft or by long hunting expeditions. On one occasion I nearly added a husky to my bag. I came upon him among the spruces some miles inland, and had already thrown the rifle to my shoulder when I recognised that the creature slinking through the shadows was not a wolf, but a dog.

Summer is the hard season for the husky, his owner probably thinking that as he does no work at that time he needs no food; but as soon as the snow comes and the komatiks or sledges appear the lot of the husky undergoes a change. He is then fed and looked after as much as he needs, and the latter at least more than he likes. $\mathrm{He}$ is the outward and visible sign of the prosperity and status of his owner. A man possessing four dogs is poor, eight makes him well-to-do, while a livyere who can count upon sixteen has attained the dignity of a very solid yeoman of the Labrador.

But the huskies have taken us far from our theme. Mrs. Broomfield told us that her husband and son were in 
summer quarters at the end of the bay, so after a most grateful cup of tea we once more manned our trap-boat and pursued our way between the indrawing shores. Rather more than a couple of hours brought us within sight of our destination and of two men in green flat-bottomed boats, who were seal-hunting at the mouth of a river. These proved to be Broomfield and his son, and they rowed out to meet us, so that very soon we were all on shore collected round a fire. The same evening our crew departed, as the wind had shifted to a quarter which promised a clear run down the estuary, and Jack and I were left with the trappers.

That night, as we smoked our pipes in the glow of the camp fire, we gained at last some first-hand information about the caribou.

For the previous seven or eight years one of the main herds (so far as I know, it is generally believed there are three in the peninsula of Labrador) had put in an appearance in the vicinity of Sam Broomfield's house between the 5th and Igth of November. Only the year before the old trapper and his son had shot thirty animals, and Mrs. Broomfield had watched a part of the migration from her back window. These facts, though exceedingly interesting, came in the nature of a blow to my hopes, for it was perfectly obvious that, as I had to join the steamer at Fanny's Harbour on the I6th of October, the caribou would still be some hundreds of miles away when I must perforce bid farewell to Jack Lane's Bay.

Though bereft of any chance of seeing "la foule," as the French Canadians of Hudson's Bay call the great migration of the caribou, Sam considered it quite possible that we might, to use his own words, "come up with some stag that's got left behind," and with a view to doing this we traversed the woods and barrens round the end of the inlet for the next few days. Our efforts proved entirely fruitless, for we saw neither track nor sign of any animal whatever 
save foxes. Once Sam, looking over the vast landscape of fir and spruce interspersed with wide and dismal marshes, remarked, "The Labrador do make a man feel terrible lonesome." I do not think any words could have bettered this description.

It brought to mind also the fact that here in the far north, where the limitless barrens set no bounds to his wanderings, the caribou is a most elusive animal, capricious and uncertain in the line of his migrations. Yet the Indians, Montagnais and Nascaupees of Labrador, as well as the Eskimo tribes of the north, have nothing but the herds between them and the grim shape of "Bukadawin" (Famine) who sat in Hiawatha's wigwam. Bands of the Indians and Eskimo pass away into the barrens every year to search for the caribou ; if they cut the line of migration they fare sumptuously and, moreover, make provision for the winter for their families. But should they fail to meet them, there is often an end to their hunting, and the squaws down in the timber lands watch in vain for their return. How many times, one wonders, has a company of Indians struggled forward, staring at the horizon, where white snow meets grey sky, straining their eyes for the shapes which are perhaps passing in thousands just beyond a man's sight to the east or the west of them. The story is told of such a party of hunters who waited and watched in vain. One died and then another; whatever weakness any individual had, it found him out, until at last but two were left, and they also had turned their faces to the skin wall of the fireless tent, when the stronger, crawling to the door, saw a forest of horns growing up against the wide sunrise as unnumbered deer moved slowly out of the north-east.

Having exhausted the hunting-grounds about the inlet, we derived some fresh encouragement from a statement of Sam's to the effect that one September some seventeen years earlier a band of Eskimo had visited a lake lying to the 
south-west and there had killed nineteen deer and two black bears. He further said that we could reach another lake on the same chain by travelling up Jack's Brook, a stream which flows into the inlet from the north; also, that by taking this route I should include in my huntingground the large sand-ridges which trend inland in that neighbourhood. Were I to go to Labrador again, I should follow a different route, and would, I think, run every chance of reaching the main herd of so-called Barrenland caribou. This herd is on the George River in August, and during that month enters the isolated timber, working out to the coast in the following November.

Thus the herd spends its year half in the woodlands and half upon the barrens, and for that reason it would seem as if the name Barrenland caribou is a misnomer. The animals are smaller than their Newfoundland collaterals, and carry fine antlers ; one in my possession measures fifty-six inches in length, and another carries a pair of brow-antlers-always rare in the caribou-and counts forty-five points. These two heads were shot-I believe by Eskimo-from the herd which reaches the coast in the neighbourhood of Davis Inlet.

It only remained to follow Broomfield's counsel and try our luck at Jack's Brook, in the hope of finding a stag that had summered upon one of the sandy ridges. According to Sam, some ten or fifteen years earlier a few deer were always to be found on the edges of the high bare upland which stretches from within a mile of his house right into the interior of the peninsula of Labrador. In winter the Broomfields, father and son, make long trapping expeditions by komatik through this country, but for many years it has been left in peace by the Eskimo, who now hunt only in the spring. It was eleven years, Broomfield said, since he had killed a deer in the summer or early fall, and it was upon this rather hopeless information that Jack Wells and I rowed down the 
bay until we came to the mouth of Jack Lane's Brook-to give it its full name. Here, seeing some ducks and waders, we did a little shooting for the pot before starting in earnest.

A few hours later we were engaged in hauling our craft up a small rapid, when we perceived a figure approaching us along the north bank. It was that of a very old halfbreed. A white forked beard swept his breast, and as we came nearer we saw that he was clad from head to foot in sealskins. His name was Old Man Lane, though whether it was to him or to his father that the locality owed its title we did not learn. He told us that he had been setting a bear-trap a mile or so above, and on our return when we mentioned our meeting with him we heard that, having taken a bear in a trap earlier in the season, the old man, finding himself without a gun, had gone steadily to work and stoned the bear to death. But as we saw him crooked with rheumatism he seemed to have scarcely vitality to stagger over the rough ground.

A couple of evenings later, having spent the intervening time in the ordinary routine of travel and reconnoitring, Jack Wells and I made our camp in a disused lodge which must have been originally built by Eskimo hunters. We had now gained a fair idea of the nature of the country. Endless barrens, white, yellow, and red with reindeer moss, and dotted with Arctic berries, rolled away until they merged in a dim blue tumult of mountains which shut in the horizon; here and there in the hollows of the hills stood little clumps of evergreen trees, overgrown with moss, harps for the wind, inexpressibly lonely. There were marshes also and deep lakes, unchristened as yet, for the surface of Labrador is mostly water and the smaller lochs are nameless. Nor is this unnatural, seeing that the settlers only visit them when they are frozen and obliterated by a mantle of snow.

Certainly it is a wild and gloomy country, far more 
sterile than the wildest parts of Newfoundland, a fact upon which Jack always laid emphasis when he lit the camp fire, bemoaning the absence of birch bark, and evidently holding but a poor opinion of a country where, as he said, a man could not "get warm to rights." On the evening upon which we made our camp in the deserted cabin beside the shores of the lake, I took my rifle and went for a stroll on the heights to the south of the outlet. It had rained in the day, and the black flies had been exceedingly pressing in their attentions; but with the evening a wind blew out of the north-west, always a herald of fine weather in the Labrador autumn, the heavy clouds and the sultry airs passed away, giving place to the clear blue northern sky. My way led me over a series of ridges which seemed to roll for miles upward to the height of land. It was impossible for hundreds of yards at a time to put down one's foot without crushing masses of purple and yellow berries. The Arctic summer may be short, but it crowds into its brief life a wealth of achievement. To man Labrador is, in all her moods, cruelly inhospitable, but to fur and feather she is during the autumn months a kindly stepmother. As I walked forward covey after covey of spruce grouse rose wild from their feast of berries. A few nights before we had seen and marked down thirty of these birds within two hundred yards of Broomfield's house, and with the aid of a Paradox had lessened their numbers by eleven, being at length driven to desist by the sheer tameness of our quarry. But here, where the grouse had probably never seen man or been startled by his foot-steps, the birds rose at a hundred yards. The reason was soon obvious, for along the height of the ridge the ground was seamed with fox-tracks.

I had been walking not more than half an hour when, taking a zigzag path up a hillside, I entered a grove of trees and beneath a juniper cut the track of a black bear. Following it, I soon came upon evident sign of its freshness, 
for in the soft ground it was perfectly clear that it had been made since the rain. The bear had been feeding upon the berries over which I had walked, and moreover he had dined not wisely but too well, since, after the manner of the Roman emperors, the great creature had vomited a part of his feast and had begun feeding again immediately afterwards. I do not think the bear could at any time have been more than two or three minutes ahead of me, and had I hurried across the moss where my foot-falls were noiseless it is quite possible that I should have seen him before he entered an area of bush where the highest juniper did not reach ten feet, but where low scrub and fallen timber made it necessary to clear the ground before every step. Twenty yards deep in this unfortunate thicket I heard the bear moving on my right hand. Here the bushes appeared to open out, and seeing free ground underfoot I walked rapidly in that direction. But this time defeat came from above, not from below. The jagged branches of a dead pine touched the felt hat I was wearing, producing a thin and penetrating sound. I heard two sticks break, and a moment later was gazing sadly at the tracks of what must have been a very startled bear.

I followed the trail, which soon showed that its maker had slowed, but evidently with no intention of stopping. This led me out on to a high barren, from which I searched in vain for any patch of black, moving or stationary. The sun was going down behind the mountains. As I watched, it sank almost visibly from view, leaving behind it a cold, milk-white twilight, which slowly darkened to night. The bear had led me in something of a circle, so that I came out hardly a mile from camp. The wind had died away, and every sound was audible. A splash in the lake, or so I fancied, as Jack drew water for the evening meal, was followed by the desolate cry of a mother loon, who, doubtless terrified by his appearance, circled and screamed at an 
immense height above the half-grown feathery balls which represented her brood, and which would one day be great northern divers weighing $9 \mathrm{lbs}$. apiece, and capable of killing the largest trout and ounaniche.

Presently her cries ceased, and the splash of her plunge into the lake came quite clearly. Then it seemed to grow rapidly darker, the wild had gone to its rest, the circle of sight narrowed, darkness seemed to lie in pools in every hollow, and, long before I saw Jack crouched beside the open fire, the stars had come out and the owls were calling in the green timber on the shores of the lake.

Making Igloo Camp our headquarters, we spent the next and following days in long rovings about the surrounding country. Once we found a fortnight-old track of a caribou stag, and twice a young spruce tree stripped of its bark, but the stags which had rubbed the velvet from their horns among the branches had done so at least a couple of years before, as not only were the trees long dead, but their fellows had grown up and overtopped them. Yet even if the country lacked what we most wished to find, it possessed a singular, if harsh, charm of its own. One spot particularly I used to love to visit, whether alone or in Jack's company. This was a little lake which lay some two miles to the north-west of our camp. Surrounded by trees and seemingly of great depth, it presented the appearance of an unfathomable pit sunk into the roots of the hills. The inevitable diver and her brood called ceaselessly upon its waters, bringing back to memory the beautiful and poetic words of Saltatha, the Yellowknife Indian, "You say the Kingdom of Heaven is good, my father; but tell me, is it better than the land of the musk-ox in summer, when the lakes are sometimes misty and sometimes blue, and the loons cry often? That is good, my father, and if Heaven is better, I shall be willing to dwell there until I am very, very old." Besides the loons two ospreys haunted 
the little lake, sometimes fishing in the shallow stream which fed it, sometimes winging their way over it and out into the blue distance towards the sea.

But here Indians, poetical or otherwise, rarely come, their hunting-ground being hundreds of miles away in the neighbourhood of the George River. Sometimes in birchbark canoes they travel down out of the interior to do their yearly trade at the Hudson's Bay posts of Davis Inlet and North-West River. Then, having bartered their furs, there follows a few days' lounging about the store. The Mountaineers, or Montagnais, are no longer always the picturesque figures they once were. Instead of the caribou skin coats figured and painted with strange devices, some now wear a summer garb of felt hat, trade shirt, and blue jean jumpers. All that remains of the ancient dress are the deerskin moccasins worked by their women in their winter camps. Powder and ball, tea and tobacco, a little bright-coloured finery for the women (whom they never bring down to the east coast), form their currency, and presently one morning, after a ceremonious farewell, the birch-bark canoes are loaded and their owners paddle away into the wilderness and vanish for another year. They are accompanied upon their journey by their hunting dogs, small and quick-footed creatures quite unlike the husky in appearance.

Day after day from all the high hills I used to search for the smoke of Indian fires, as for some reason that year neither the Montagnais nor the Nascaupees came in any numbers to the posts. During this time it was bright, windy weather; the wind never dropped, but blew so fiercely that it made the eyes ache. The same wind, had we known it, was preparing the way for a tragedy to the south of us. It was this pitiless wind which delayed the Hubbard expedition and finally caused them to turn and to attempt to struggle back through the long valley of 
the Susan River. They had set out early in the season and had pushed on, hoping always to find the caribou, on which they depended for food, but in all their wanderings they killed but one animal, so that finally, weakened by hunger, and beset by snows, poor young Hubbard succumbed, after a most gallant struggle, while his two companions, pushing on to get help, could not bring it until too late.

The story of the journey of George Elson, who, feeding as he could on grouse and porcupine, fought his way to Grosswater Bay, is one of the epics of the Men of the Woods, and it can be read, and should be read, in " A Woman's Way through Unknown Labrador," which tells also how Hubbard's widow undertook the task her husband had given his life for, and carried it through with a splendid courage to success.

On the fifth day on rising in the morning I found that two large bears had visited the vicinity of the camp during the night. The almost human track passed within fifty yards of our cabin, when doubtless the smoke of the fire had sent both animals off at speed. After a couple of days spent in earnestly searching for sign or sight of game, we broke camp and passed to other hunting-grounds. But in all the days we spent in Labrador neither of us saw either bear or caribou in the flesh.

It was the $7^{\text {th }}$ of October when we again found ourselves at Broomfield's house. Here I learned that the summer colony of cod-fishers at Fanny's Harbour had already departed for the south, and the captain of the Virginia Lake doubted whether the Newfoundland Government (in this matter the Reid Company are the agents of Government) would sanction the steamer's venturing so far north as the date arranged, but he had promised to pick me up at Hopedale, sixty miles to the south, about the I5th of the month. It was now that the trap-boat proved of service.

Sam was absent on his monthly errand to fetch the 
mails, and incidentally my boat, from Fanny's Harbour. We, while awaiting his return, thoroughly explored the inlet. It was at the north-western end of this creek that Sam had enjoyed his never-to-be-forgotten hunt some seven years before our visit, when one day he saw a large brownish creature lumbering through the woods, cut it off behind a clump of spruces and killed it with a ball from his rifle. It was not until he was bending over his quarry that he discovered that he had slain a polar bear. Its nose and jowl were full of porcupine quills, and the fact that it had been rolling in the mud of the river-bank, probably in its efforts to get rid of the quills, had turned it into a likeness of a gigantic Barren ground bear. The deaths of this animal and of seven walrus that were slain by the Eskimo at Hopedale form the two red-letter events of which every visitor to that region is sure to hear. But we, alas! had no good fortune; our single success being scored at the expense of a grey seal that was fishing at the mouth of the river. For the rest, we only succeeded in keeping ourselves and the Broomfield family supplied with feathered game.

At length I was beginning to grow anxious about catching my steamer, as the winter was rapidly closing in, when at last Sam put in a welcome appearance with my boat. The morning following, he and his son, Wells and myself, with a step-son of Old Man Lane named Sandy Gear, started on our sixty miles' voyage to the south. This distance we expected to be able to make by the afternoon of the next day, but, owing to contrary winds, evening found us still within the broad-spread arms of Jack Lane's Bay, and in the morning, after a night ashore round an open fire, the wind hardened to a gale, which blew almost in our faces and prevented our making much progress. As such storms often hold back the traveller in Labrador a week or more at that season, we lost no opportunity to 
push ahead, but after a day spent toiling at the oars, which were of the narrow-bladed pattern that girth some twelve or fourteen inches below the grip, we found ourselves wind-bound at nightfall. On the following day the weather had become worse, and had it been necessary to cross much open water we should have been forced to anchor. Our way, however, lay among the islands, until we reached the long rock-walled stretch of water which is called Windy Tickle. In certain winds Windy Tickle is quite impassable, as the gales roar down it like a league-long funnel, the sheer cliffs on either hand rising some hundreds of feet from the level of the sea.

As I had left most of our provisions with our kind friend Mrs. Broomfield, we suddenly discovered that beyond a little tea and tobacco and a half-loaf of bread our stock was at an end. We therefore ran across to a rocky island locally famed as the breeding place of the Arctic hare. But the most careful search and earnest efforts of Sam, Abraham, Jack, and Sandy-all of whom probably for the first time in their lives took part in a hare-drive-resulted only in the flushing of one or two twittering inhabitants of the isle which Sam called snowbirds, and which were quite unworthy of a twelve-bore cartridge. The hares were either altogether absent or remained in shy seclusion, and food having become a necessity, I succeeded, amid the plaudits of the crew, in massacring five gulls, one for each man. These were rapidly skinned, placed in a large iron pot and drawn out of it while the water was still almost lukewarm, but not before Sam, having discovered the lack of salt, had found time to add a hatful of seawater ! The birds, contrary to expectation, or because hunger is so good a sauce, were much appreciated, and from that time onwards until we arrived at Hopedale no herring gull or blackback flew into sight without drawing the eager eyes of the crew of the trap-boat. 
But all things have an end, and at length in the evening, turning a high bluff, we saw before us the lights of Hopedale, and soon heard the long ululating cry with which the Eskimo announce the arrival of a strange boat. Soon we tied up against the wharf and were making the acquaintance of the Rev. W. W. Perrett, the house-father of Hopedale Mission, and one of the most charming men it would be possible to meet anywhere. While the crew sought the hospitality of one of Sam's sons-in-law, Jack and I went up to the mission house, where a dish of canned caribou was quickly set smoking before us, and $\mathrm{Mr}$. and Mrs. Perrett were asking and giving news of the coast.

The voyage to Hopedale, with its mild experiences of roughing it, would have been thoroughly enjoyable but for the fears which beset me concerning the arrival and departure of the mail-boat, doubts which were not much allayed by Sam's assurance that if I missed her I must stay over the winter with him and that I should then have an opportunity of shooting the finest lot of caribou trophies ever taken out of the Labrador. This probably might have proved true, as up to that time no one with any motive beyond that of killing meat had pursued the herds; yet the prospect of an enforced residence of eight months was not one to be calmly anticipated, the more especially as it would have been impossible for me to communicate the reason of my detention to my relatives, or indeed to Jack's, who assured me that his wife at Glovertown, Bonavista Bay, would say in the words of Penelope :

\section{"... Either he is drowned,}

Or else his bones lie on the mainland in the rain."

Or, as he more prosaically put it, "I would be give up in our bay for dead and eat by Eskimo on the Labrador."

But the steamer had not arrived, nor did she put in an appearance for three or four days. During the inter- 
val I saw something of life at the mission station. It is impossible here to do any justice to the magnificent work of the Moravian Brethren. Quite apart from their efforts in the cause of Christianity, it is my belief that but for their restraining influence and aid the Eskimo population of the southern Labrador would have vanished almost completely. It is well known that no race is more liable to suffer disastrous consequences from unchecked contact with civilisation than are the Eskimo. Dr. Nansen has put it on record that even so mild a luxury as coffee has very traceable effects upon the constitutions of this people, and it is certain that the Moravian missionaries have stood between the Eskimo and indulgence in stimulants far more deleterious than coffee.

The mission stations of Okak, Nain, Hebron, Hopedale and Makkovik, extending as they do along many degrees of latitude, form sanctuaries for the converts, where under the wise and benign rule of the house-father (as the head of each station is called) they are encouraged to live an existence which preserves as far as possible all that is manly and wholesome in their characters. The influence which has led not only to the degradation, but almost to the extinction, of the Eskimo upon other littorals has invariably taken the shape of strong drink. Against such traffic the missionaries resolutely set their faces. Had they not done so, the Eskimo would beyond all doubt long since have become the victims of the itinerant trader, and instead of being to-day a healthy and self-supporting community, the race would a generation ago have vanished from the Labrador.

Thus it is not too much to say that the Moravians are responsible for the survival of the people to whom they devote their lives. While holding the finest record in the missionary field of any Church in the world, a Moravian settlement brings with it immense boons of a material nature, 
Each individual missionary has learned and is expert in the medical profession, or in some trade likely to be useful to his converts. Dr. Jannasch built the church and missionhouse at Makkovik, and the Eskimo workmen who assisted him have since turned their attention to their own dwellings. Other missionaries build boats; others, again, understand the theory and practice of gaining their living from the sea; and so the work goes on. All are practical men, who labour shoulder to shoulder with their people, and who in this manner establish a mental leadership which is bracing and effective. On the spiritual side of the question, I believe that a large proportion of the children of missionaries return to the mission-field to follow in their fathers' steps. Certainly no financial inducements are offered, for in Labrador, at any rate, the salaries of these devoted men range from $£ 9$ to $£ 23$ a year. Often they pass ten or even twenty years without returning to Europe, and when they do come it is but for a short time, between the visits of the Harmony, the mission ship which keeps up the yearly communication between England and the coast of Labrador. It is pleasant to think that the Church of England has for many years aided the Moravians by means of an affiliated society. One thing at least is unquestionable-that every sovereign which the people of England and America and Germany subscribe towards the Moravian Church is made to do the work of two or three times that sum by the single-heartedness and the capacity with which it is administered.

The Moravians in Labrador have experienced one or two strange difficulties in their task. Of these the smallest is making the Old Testament, with its wealth of pastoral detail, understandable to the Eskimo, not one of whom has ever seen a horse. Sheep and cattle they cannot realise or conceive of, for there are no domesticated animals save dogs in that portion of the peninsula. They 
comprehend the story of Esau the hunter and that of Samson and the lion, which animal can be translated as Polar bear, but of Abraham in the land of Mesopotamia they can form no picture; the nearest approach to these ideas is drawn from the harvest of the sea, seals and fish taking the place of flocks and herds. So is the Bible interpreted to the harsh meanings of northern life.

One picture of Hopedale is still very vivid. On the day after our arrival an old Eskimo hunter had died, and his fellows bore his body to a wild high bluff along the sides of which generations of their race have been buried. At the head of the procession walked the brother, who was conducting the service, and up the steep path was strung out the entire population of Hopedale. Among the huts some of the dogs were howling, a flock of gulls circled screaming on the shore, and from the cemetery came the sound of singing. The detached syllables, strange to a European ear, blended oddly with a tune that one has heard in a hundred churches, floated back on the frosty air.

At last one day, having set an Eskimo to watch for the mail-boat's coming, I, accompanied by one or two of the Moravians, set out, hoping to add some grouse to our bill of fare. As we returned with three birds in the evening we found our sentinel happily asleep in the icy wind and the Virginia Lake steaming up the channel and about to lie-to in the fiord-like bay.

'Within a week we disembarked at St. John's.

Finally, a word or two about the caribou of Labrador may perhaps not be out of place. The only certain information that I was able to gather was as follows:- In the southern parts the woodland caribou has been practically exterminated, though all over the country they may still be met with in very small numbers. The Hubbard expedition, I903, which spent over three months in the interior, killed but one stag, and it is probable that these animals 
have been so thinned out as to make an expedition in pursuit of them hardly worth the time, trouble, and expense it would entail.

With regard to the Barrenground caribou the case is different. I was told that in some years the herds fail to make their usual November migration to the coast, and in other years when they do migrate they appear in diminished numbers. Also they do not each season visit the same spots on the coast, but come out to the salt water at points far distant from each other; for instance, Sam Broomfield has shot but few deer lately, though formerly they showed in great numbers at Jack Lane's Bay.

On the other hand, Mrs. Leonidas Hubbard writes that in I906 she witnessed the migration near the head-waters of the George River, but at a date, August 8th, when the horns were still in velvet.

For the hunter who wishes to find these caribou only two courses seem to be possible. The one is to winter in the Labrador and spend the late autumn on the hills and barrens behind Davis Inlet, Hopedale, or Makkovik; the other would be to make arrangements to arrive in Labrador in the early summer at the first break-up of the ice and to undertake an extended canoe and packing journey up Hamilton Inlet, Grand Lake to Lake Michimakau, and Michimakats. Provisions must be carried for every day spent in the country, as, except for fish and birds, the region to be traversed is practically gameless. On the upper waters of the George River the hunter would be as likely to find the deer as anywhere, but, since the migrations are of so arbitrary a nature, this would by no means be a certainty, though single stags might be seen.

Since writing the above I have learned that vast forest fires have altered the line of migration, and the trend is now much further inland than before. 


\section{CHAPTER IV.}

A FALL HUNTING TRIP IN NEWFOUNDLAND.

STARTED for my first trip in Newfoundland on the 23rd of October, I903. I had landed on the island some weeks earlier, on my way to the Labrador, and the second shooting season had already commenced, when the Virginia Lake, returning from the peninsula, carried me for a second time between the two dark bluffs that guard St. John's Harbour. St. John's is a town of steep streets and cobbles, built about the hill-bound mouth of the estuary which forms the roadstead. Often drenched in sea mists, sometimes blurred with rain, yet on a blue September day, when the mists have gone, or only drift in tatters about the brown heights, with an iceberg, picturesque if dangerous, stranded in the narrows, it is as beautiful a place in its own way as any town in North America that I have seen, saving only Quebec.

The inhabitants of St. John's may all be said to derive their living from the sea. Clusters of sealers and whalers lie anchored in mid-harbour, busy schooners ply for cod to the Labrador and the Banks, while many of the business houses have their own private wharves. Pelts, fur and fish, all the products of the Arctic, find their way to this emporium of the ocean, and as the sea is fickle, so trade and prosperity there suffer a more than common tyranny of ebb and flow. In spring, when the sealers go forth for their three weeks' season, no one can foretell 
whether they will each make a small fortune or lose one; the hands receive no regular wages, but every individual a pro ratâ share of the profits of the venture. The case is much the same with the cod-fishery. The sea is the mistress whom all serve, directly or indirectly; the financial veins of the community draw-when she permits it-life and vigour from her bounties.

A less romantic place than the store of a grocery and general dealer can hardly be imagined, yet the grocery stores in St. John's are nothing if not romantic to those whose eyes are open. Besides flour, bacon, and tea, they sell their axes, rope, canoes, sealskin boots, all the dozen necessaries for a trip up the coast or into the interior. In them you will often see a group of sinewy, weather-beaten, seafaring men fingering material for women's gowns and consulting long and gravely on the choice to be taken home for the wives, sisters, and children away in the outports. As, then, the sea dominates Newfoundland, it is quite in the nature of things that caribou and other game should be in charge of the Department of Marine and Fisheries, and very well indeed that department does its work.

There certainly still hangs about this oldest of the British colonies some remnant of the glamour which is inseparable from the ancient maps that carry marked upon their parchments such phrases as "Here be many bears " and "Here be great deer." It was the fame of the latter that drew me to Newfoundland, for no longer can any region in the island boast of " many bears." As to Polar bears, not one remains, although an occasional specimen is now and then carried into the Straits of Belle Isle on an ice-floe ; some few black bears still exist, however, in the interior. But if the bears have dwindled in numbers, the great deer still wander there.

The inland solitudes of forest and marsh give sanc- 
tuary to huge herds of woodland caribou. The caribou of Newfoundland carries the finest antlers of any local variety of the woodland reindeer family. These antlers, while they lack the beautiful length and curve of the Barrenland divisions that inhabit the high field of Norway or the uplands and barren lands of Arctic America, are remarkable for a weight and density of horn which places them among the most desirable trophies that can still fall to the hunter.

Nor can set-up specimens do more than indicate the beauty of the animal as he appears in his native wilds. The symmetry of his mighty body and limbs, the dark face contrasting with the white-maned neck, the broad brow antlers clasped together like hands in prayer, the palmated bays and lofty tops, must be seen in their proper environment to be appreciated. This is, no doubt, true of all the deer family, but it applies in a rather special way to the caribou, if only for the reason that the grime of cities quickly tarnishes the sheen of these white-necked stags.

The game laws of Newfoundland allow two seasons to the sportsman. The first covers two months, from the Ist of August to the 3oth of September inclusive, after which it closes for twenty days, during which the rut is at its height ; it opens again on the 2Ist of October and extends to the Ist of February of the following year. As a matter of fact, however, only the very early days of the long second season are of value to anyone in search of a trophy, as the stags begin to drop their horns as early as the Ist of November, and by the roth of that month many, if not most, of the finest antlers have fallen, for it is always the monarchs of the herds who are the first to lose them, as they are the first to rub the velvet from them in the opening of September. The hunter should therefore choose the month of September or the first three weeks of the later season for his campaign into the interior of the island. 
There are, it may be mentioned, a certain number of individuals who never attempt to reach the interior, whose ambition is satisfied by what may be called the " railway sport," and who possibly deserve any disappointments that fall to their lot. The term " railway sport" needs elucidation. Twice a year the caribou in Newfoundland migrate; in the spring they move from south to north, and in the autumn travel back from the north to their winter feedinggrounds. It happens that the railroad from St. John's to Port-aux-Basques intersects a main route of migration, and immense numbers of deer cross the line, the bulk of them reaching it near a station called Howley. This is the spot haunted during the earlier part of the shooting season by the "railway sports," for it is often possible to shoot the three stags allowed by law without walking out of sight of the metals. Yearly, as might be expected, a multitude of immature stags are slaughtered in this way, and the ears of passengers in the passing trains may be filled with the report of guns, as if a small skirmish were taking place!

From this form of shooting all the chief elements of true sport are eliminated. The numbers of the hunters (who camp in groups), their method of sitting down until the deer come to them, and the ineradicable spirit of competition which leads some men to shoot at everything they see without much discrimination are all against the real interests of sport. Besides, the volley-firing has been going on every September and October for some years, and in consequence this great herd has suffered in many ways. In addition to the " railway sports," the Newfoundland settlers often resort to Howley to obtain meat for the winter, with the result that many does and two-year-old stags are killed. The settlers' reason for going to Howley is both obvious and natural, as all the meat secured can be placed upon the train and transported with ease and comfort along 
the line to the men's homes. But in the eyes of persons who voyage some thousands of miles to hunt caribou the "railway sport" is unlikely to offer many attractions. Probably they may be inclined to echo the saying ascribed to a famous hunter: "I have come all this way to hunt caribou, not to allow caribou to hunt me!"

Until recently the opinion was commonly held that all the caribou in the island crossed the line of railway during their migrations, but since hunters have gone further afield their observations tend to prove that this is by no means the case. Mr. F. C. Selous, the first of these hunters, shot some large stags in the early September of Igor close to John's Pond, a spot where at that date no deer would have been had the theory of a universal migration been correct.

The deer of Newfoundland may be divided with some accuracy into three main groups. The best known is that herd which crosses the railway in its migration, going north in spring and returning south in September and October. The second herd, or, rather, vast body of deer, inhabits all central Newfoundland from St. George's to Port Blandford and migrates between the railway line as a northern limit and the south coast. This herd is hunted by the Micmac Indians, who have divided that part of the country into hunting-grounds. These Indians are a branch of a Nova Scotian tribe, who transferred themselves to the more northerly island about the middle of the eighteenth century. They do not resent the presence of hunters on their especial districts, though probably if trappers interfered with their rights there might be trouble. The third herd is a very small one, and consists of the few deer that still survive in the Avalon Peninsula, south of St. John's, and these do not, I believe, migrate at all.

In the vast interior of the country are thousands of caribou which have probably never been within many miles of the railroad, and it is towards these herds that one 
would wish to make one's way. Here is a wild and empty land, inhabited only by a few hundred Indians, uncounted deer, and, for the rest, beaver, a few black bears, many lynx, foxes and other of the smaller fur-bearing animals, with, few and far between, the dying remnant of the wolfpacks, for whose slaughter a heavy Government bounty is still, I believe, offered, though very rarely claimed.

By the game laws of the island the shooting licence costs $\$ 50$, and now its holder is limited to the killing of three stags, though under the old licence five stags and two does were allowed. A resident of the island is limited to five caribou, but should a Newfoundlander be employed as guide by a non-resident he is, very wisely, prohibited from exercising his right during the time he is acting in that capacity. All guides must have certificates, but a nonresident guide must also carry a licence costing $\$ 50$.

Heads are locally judged by the number of points. The average head seems to carry about twenty-five points; a proportion of one in every twenty, thirty points; while one stag in every eighty or a hundred may carry forty points or over. Most of the does grow horns, which they do not drop until April or May.

I had taken with me to the Labrador a Newfoundland guide named Jack Wells. On our return he, fresh from desolations compared with which his native outport of Glovertown, Alexander Bay, was a populous centre, rejoiced to set foot again in a land where, as he said, " a man might see a body now and again what wasn't a Huskimaw." He left me in St. John's, where I spent one comfortable night between sheets, while he went on to find two other men in Glovertown with whose help it might be possible to " pack" well into the country from the head of George's Pond.

Jack was afraid that, so late in the season, the best woodsmen would be already engaged, or away trapping, a 
prediction happily not fulfilled, for he was able to secure his brother Frank-a "foxy man," as Jack described him, meaning red-haired and bearded, a man with as genial a temper and as broad a back as ever added to the gaiety of a camp. With Frank he engaged George Arnold, a quiet, religious, hard-working individual of fifty or so, to whom I took a great liking.

While Jack was thus making up the strength of the party in Glovertown I bought the few necessaries of which we were short, and also my licence, to which the Newfoundland Government, in most kind recognition of my recent attempt to open up the Labrador as a sporting-field, added the right to kill some extra stags. Then, in the afternoon, my friend Judge Prowse, who had interested himself in the success of my trip to an extent for which I shall always be grateful, drove me to the station at the upper end of the town by the head of the estuary. From there the railway runs for five hundred and thirty-seven miles, first north, then in a south-westerly curve to Port-aux-Basques on Cabot Strait, the point of departure for Canadian territory.

The railway is now under the control of the enterprising Reid Newfoundland Company. Through forests, over rivers, beside lakes, the line runs, with a station every dozen miles or so, a station that often consists of no more than the wooden cabin of the section-man, whose business it is to keep the permanent way.

My destination, Terra Nova, lies one hundred and seventy-one miles distant from St. John's, and is reached in something over eight hours by the express ; thus it was far into the small hours-shortly before three o'clock, in fact-when the train attendant put his head into my sleeping-car and informed me that twenty minutes more would bring me to my station. The train was running with a roar and a creak between deep woods of spruce, that flashed 
at intervals into star-lit waters. But at that hour, between night and morning, one thinks little of the charms of scenery, the more especially as there was barely time to dress before we began to slacken speed and finally to draw up. My baggage, my "camp" as it is called in Newfoundland, was dropped out and stacked beside the metals, the conductor's voice echoed through the frosty air, and the train swung away out of sight, the louder clang as it disappeared telling of the trestle bridge across the head of Terra Nova Lake.

I found refuge in the single wooden house of Tim Hawco, the section-man. Lonely as was the spot, it knew nothing of the silences of solitude, for in the little room of the railway agent the telegraph machine never seemed to cease its clatter for ten minutes, day or night. Such was Terra Nova in I903, but since then a lumber mill and the men employed in its working have altered the place a good deal.

I found that my men had not yet arrived from Alexander Bay, but was not much surprised, as they were to come by an "accommodation." The trains run by the Reid Company are of two kinds-the express and the accommodation. How the latter came by its name I do not know, unless it be that it is the duty of an accommodation train to accommodate; but, to judge from the opinions freely offered by its passengers, it does not altogether achieve success in this respect. Its speed rarely averages fifteen miles an hour, with further delays of stoppages to collect or to set down freight, or to allow the express to passdelays which sometimes run into hours, a hardship not a little accentuated by the fact that nothing in the shape of food is procurable on board. There is, I have heard, a rule on the Reid line that any train twelve hours behind the scheduled time becomes a special-a great many accommodations must become specials! Many people, especially 
sportsmen, grumble, which is, after all, rather absurd, as they always have the alternative of the express, which, considering the route, is punctual and certainly most comfortable. It would be just as reasonable of a traveller in England who, choosing a goods train, felt himself aggrieved because it failed to run mile for mile with the Scotch Express. But it is the fashion to deride the accommodation; and what has justice to do with a time-honoured joke?

On reaching the station-house I turned into my sleeping bag for what remained of the night, and woke to find it raining. I went down through the rain to the banks of the Terra Nova River. The dawn was full of the scent of wet woods, for the wind was blowing across the water. To my right the river, broad and peaceful, wound away under the gaunt trestle bridge, between flat green country darkened here and there with woodland; to the west spread the lake, dotted with rocks at the nearer end. It was pleasant to stand there and think that to the westward lay the centre of Newfoundland, where no man lived, and that, although this is the oldest colony of Great Britain, it is possible even to-day, within eight or ten days' travel of the railway, to walk into almost unexplored country.

The landscape is covered with a network of lakes, surrounded in almost every instance by woods; it is intersected by marshes and broken by the knobs and ridges of the barrens. These barrens show great spreads of sulphurcoloured reindeer moss, and a loose scattering of trees, which gather here and there into clumps, or "drogues," of spruce, of juniper, or of birch. Few people have invaded these solitudes. Sportsmen camp there in the autumn, and settlers from Alexander Bay, who come to collect their winter store of meat ; but the latter, for reasons of easier transport, keep as near to the railroad as possible. Prospectors for timber and Indians have lit their fires in some of these wild spots, but though the lumber camps are being pushed 
further and further into the interior, still a great portion of it remains to-day uninhabited, trodden only by the deer and the lynx, an occasional bear, or coveys of willow-grouse; but these birds are found in much larger numbers more to the south.

Two successful hunting trips had already taken Terra Nova as their point of departure, one being that of $\mathrm{Mr}$. Selous, to which I have already alluded ; and in the following year that of Mr. J. G. Millais. Both these had been September trips, and it yet remained to be seen what luck a hunter would meet with who spent October in approximately the same district. I had planned to go some little distance above the head of George's Pond in canoes, and there to "take the country." We carried provisions for four weeks, a change of clothes apiece, and our sleeping gear.

After breakfasting, I spent the morning in doing the half-dozen odd jobs that always gather about the outset of a journey. Life contains many good moments, but few, I think, better worth living than those anticipatory ones passed in making ready to start for new, or indeed for familiar, hunting-grounds.

The train from the north was some hours late, and did not come in till one o'clock, and when it arrived I learned that a canoe on which I had relied, and which Jack was to bring from Glovertown, was unfortunately not available. This might very easily have caused me a long delay had it not been for the fortunate and accidental presence of a large flat-bottomed boat which belonged to an acquaintance of Jack Wells. About three o'clock, or a little later, all was prepared, and we set out, shoving off into the shallow waters of the Terra Nova, Jack Wells and myself pulling the big flat, the other two men in charge of a canvas canoe. The wind had veered and blown away the clouds of the morning, and soon the last vestiges of civilisation, the gaunt 
trestle bridge and the boat-house, disappeared behind us and we were fairly off. I wanted to push on as far as possible before dark, hoping to take advantage of the good weather, for the two lakes through which our course lay are often, at this season, impracticable for days together for such small craft as the canoe. But although the evening had settled to fine, the dark came early, and soon we were obliged to camp at a spot called Woody Island, which lies at the eastern end of Terra Nova Lake.

The next morning we were up before the dawn, but the weather had changed during the night, and no sooner were we afloat than the sky became overcast, the north-west wind rose, bringing with it squalls of snow, and, a much more awkward fact to face, showed a tendency to veer still more to the west, a development which would deprive us of the shelter of the wooded northern shore, if it did not, as was likely, altogether prevent our progress. In such weather the big boat had the best of it, for the lop of the water greatly retarded the canoe, while we, although we took our share of the lake aboard, were able to make a straighter course.

At the head of the Terra Nova Lake, where Frank Wells and his partner, Robert Brooking, had some traps, we espied a lynx, which had dragged a trap down to the sandy shore. We landed, and one of the men killed it, leaving it for Brooking to skin on his next rounds. We passed from Terra Nova Lake into George's Pond and rowed up it, hugging the shore, beneath the dense forests of spruce and juniper which descend almost to the water; and sundown found us, the lake safely astern, making our way up a dark and rather swiftly-running brook, where the trees rocked and moaned above our heads in a manner that proved how lucky we had been in getting across the lakes before the squall rose to its strength.

We had some little trouble with the unwieldy flat boat 
on account of the current, but rowed about three miles up the brook before we made our camp and pitched a floored tent on the bank. This tent, though heavy to carry on a journey, is very useful as a base camp-for which purpose it was taken - as it is made in one piece, and, except in the case of flood, nothing can get wet inside it. During the day we had seen little life, only an eagle and two red-throated divers.

On the morning of the $23 \mathrm{rd}$, having done much in the way of preparation overnight, we were able to break camp fairly early, and, having drawn the boat and canoes from the water, we shouldered our packs, containing bedding, tent, flour, tea and sugar for a week, and " took the country." My intention was to push on to Doctor's Pond, where I meant to remain and hunt with Jack Wells, while the other men travelled back to our base for more provisions.

We began at once to enter upon the barrens and marshes characteristic of the interior. Nowadays parties are yearly pushing further into newer hunting-grounds. But in the pre-railway days Sir William Kennedy with the rifle and Judge Prowse (famous as the historian of Newfoundland) with the shot-gun were the pioneers of Newfoundland sport.

Our first objective was a spot called Sir William Whiteway's Drogue. The way to it led us continually upwards through patches of woodland and across small marshes. Two or three times we came on tracks of good stags, and quite a score of smaller animals must have passed along one of the deer-trails at no very distant date. Some three miles of packing brought us to our destination.

While the midday meal was preparing Jack Wells went off with the telescope to the edge of the wood, where he climbed a tree in order to overlook a large yellow marsh which stretched ahead of us. This marsh was dotted with drogues of various sizes, some being in thick clumps, some scanty and half-transparent. By the time I followed Jack 
he told me he thought he saw a gleam of white behind some spruces that might be the neck of a stag. Seeing that the stag, if one it were, must be lying down and would probably not rise till later, I left Jack to watch and went back to the camp for some tea. I had scarcely reached it when Jack came running after me with the news that the white patch had moved, and that he was almost sure it was a good stag caribou, and he asked me if I would like to follow with my rifle at once, or wait for my tea! I relinquished my tea, and, going back with Jack, climbed the look-out tree, but it was still impossible to see more than that gleam of the white neck behind a small group of spruces. To get within shot we were obliged to make a long detour, but two or three low thickets of bush gave us pretty good cover. We were thus able to creep to within about two hundred yards of where the stag lay, when I stopped to use the telescope again, in order to see as much as I could of him. But this was no more than the tops of his antlers, which, however, appeared to be fairly well developed. We judged that he might be a thirty-pointer, and as the drogue behind which he was lying afforded excellent protection from view I managed to get extraordinarily close. We were within certainly fifty yards of him before he began to grow at all suspicious, and perhaps not more than forty before he got up. His tops were still the only part of him visible, but it was quite clear that if he happened to make off up-wind there would be no chance of a shot. On the other hand, if I fired at once, I should merely have to choose the thinnest part of the twigs and branches that concealed him and fire through them. Accordingly I fixed on the clearest spot I could see, and fired. At the shot he bolted out on the north side of the thicket just like a gigantic rabbit, and tumbled head over heels to a second bullet in the neck.

He turned out to be a heavy and large-bodied stag. 
His head carried twenty-five points, but was much knocked about by his love battles, several points having been broken off his horns. This is the case with so many stags in the October season that it is often difficult to secure an absolutely perfect head at that time of year. Had this particular animal been shot early in September, his would have been a very good trophy; still, I was pleased enough to have secured a fair stag so early. We left him to lie while we returned to camp to finish the meal of tea and hard biscuit his presence had interrupted.

Later Jack Wells and I went back to take off the head and head-skin, while the other men made up their packs and started to walk over the marsh to Beaver Pond, where we meant to camp for the night.

The following dawn was dull and grey, a heavy mist hung over the face of the marshes, so that it was difficult to see two hundred yards, and impossible to see three hundred in any direction. This mist, of course, entirely prevented our using the telescope, and was very unfavourable for stalking. Nevertheless, I went out with Jack Wells, and we had not gone very far before we saw a couple of does with one fawn feeding along in our direction. We sat down to watch them, when all at once they stopped feeding and began approaching us at a swift walk. We remained as still as the stones amongst which we sat, and they passed within fifteen paces before the leading doe winded our track. She leaped into the air, and all three dashed back, passing us again at an even less distance than before, and then were lost in the mist to the westward.

During the day we covered some twenty miles, and came across rather more than fifty does and only one stag, which carried a head of about twenty points. We stalked him to within two hundred yards and had a good look at him. His horns were long and fairly heavy, but he carried only one brow antler. The next day was Sunday, and we 
could see small parties of deer continually crossing the marsh to the east of our camp. There were one or two stags amongst them, but not very large ones.

For some time after this the weather alternated between frost and "sleepy". snow. We had one or two unpleasant days of sleet, but the sun generally showed himself for a longer or shorter time between morning and evening. During this period our camp was set in a drogue beside the small lake known as Doctor's Pond. We made our march there through a storm of sleet and snow blowing in our faces all the way, covering stones and bog-holes from our sight and rendering walking with a heavy pack disagreeable.

As we neared the pond we saw two sizable stags, but neither good enough to shoot. After a while the weather cleared and became glorious, the camp was comfortable, and in fact everything went well with us with one exceptionI was beginning to be very uneasy about securing a big stag. I had at that time seen seventeen, and shot the best one of them, but he was no more than a fair specimen. While in this camp we hunted one day in the lower country, which was full of deer travelling south, for the autumn migration was by no means at an end. The courting season was over, however, for we often saw three or four large stags feeding in amity with does round them.

All this time we never had a dull moment, and rarely went out without seeing either does or stags. We were often able to approach within one hundred yards, and many hours were spent watching the deer through the telescope. The average stag seemed to carry some twenty to twentyfive points, but of all we had yet seen not one presented two good brows, though a couple of them appeared to carry a number of points. But, as far as caribou are concerned, points mean very little. For instance, we picked up a cast antler showing fifteen points on one brow alone, and yet this was a poor and weakly-grown horn. 
In all directions deer-paths intersected the marshes, and we came upon some very large tracks. But a large track is by no means to be depended on as indicating a good head.

The 28th of October was a beautiful day, clear and brilliant, with a north-west wind and a covering of light snow lying over the face of the country. I had arranged that Frank Wells and Arnold should again go back to the base camp and bring up some more provisions; while Jack Wells and I remained to hunt towards Island Pond, a lake lying to the westward. On the previous evening we had seen several herds, and hoped that we had perhaps found a large body of the migrating deer.

However, when we set out after breakfast in the direction of Island Pond, we walked a couple of miles, seeing nothing save a couple of does. The features of the country now began to change somewhat. Large hummocky expanses of barren crowned with boulders spread ahead of us; there was less marshland, though from the hills over which we were walking we could see two or three sheets of water partially surrounded by trees. Small clumps of juniper and of birch, spruce, and pine were scattered over the landscape.

It was just past ten o'clock when we saw the first stag of that day standing on the ridge of a barren; half-a-dozen does were lying on the ground near him. As the wind happened to be favourable and the cover good, there was little difficulty in approaching within two hundred and fifty yards of him, but, to our disappointment, his head, which had looked very well against the sky-line, proved on closer inspection to be merely average, and after watching him descend to a marsh we climbed higher up the little hill we were on, and from there I descried some deer, including a tolerable stag, lying down in some soft ground to the southwest.

I was watching him intently, when Jack Wells said, 
"There is another stag on the hill over there. I think he is a good one."

It must be owned that at this time, although knowing myself to be in great luck to have come upon the deer in such numbers, I was, as has been said, rather dissatisfied with the fact that, amongst all the stags I had seen, not one carried a head unquestionably above the average.

The caribou to which Jack had just drawn my attention was close upon three-quarters of a mile away on the slope of an opposing barren. The sun had gone in for a moment, so that it was not easy to make him out with certainty. But after a little the cloud blew away, and in the brightening light I looked again, and saw a sight that filled me with hope, for the sun was shining and glinting upon the big clubbed top of his left antler. Here, undoubtedly, at last was a really splendid stag. For some time we sat and watched him feeding leisurely along the rough shoulder of the ridge, and when at length he disappeared into the dip on the farther side we set off at once.

The direction of the wind necessitated a long walk which led us across a particularly wet and shaky bit of bog, and then up over the first of a series of low rolling barrens. Here we attempted to spy the stag again, but for a time we could not locate him. At length, however, we caught sight of him coming over a slope further on. He was now facing us, standing up magnificently against the sky-line. As soon as he passed over the brow of the barren into the hollow we scrambled as quickly as we were able to the base of the one we were on, and began to run, for there appeared to be every chance that he would feed into an unstalkable position.

We crawled up and hid behind some stones in a line parallel to that in which the stag was feeding. All this time he was moving slowly on, passing behind a small group of five or six bare junipers, and we could see him nuzzling 
in the deep reindeer moss, his great antlers swaying up and down. He next partially turned away from us, and we took the opportunity of creeping into a depression at the foot of the hummock on which the stones lay and, pausing behind a small bank of moss, took another look at him through the telescope. Owing to his position it was still impossible to distinguish much beyond the fact that his horns were exceedingly heavy, but even on that count alone there could be no question about its being a grand head. He was now feeding on a mound encircled by a depression, much as a saucer surrounds a cup. We made our way along this depression and then upwards to a boulder within one hundred and twenty yards of a spot he must pass, and there we waited. Presently the big stag finished his nuzzling in the moss and slowly walked out into full view. I could perfectly see his head now, with its heavy, wide-spread horns, the one clubbed top and the other top with its five points.

He was right above us, and at the shot from the Mannlicher he walked two or three paces forward and crashed down, rolling over. We at once ran up the hill, and found the bullet had entered under his chest, coming out through his back. I had known all the time that he was an uncommonly good stag, but I was not prepared for the weight of horn resting upon the moss. He carried thirty-five large points, but the antlers, which were extraordinarily wide and heavy, were uneven, the right being clubbed, as I have said. He was undoubtedly an old stag, and was certainly going back in the perfection of his horns.

After this, very pleased with our good fortune, we went off to our lunch, which we took in the shelter of a small drogue, filling our kettles from a shallow upland pond, blown into a thousand ripples by the wind. During the meal a heavy cloud drifted up, and snow began to fail thickly. For a while the sky to windward remained bleak and drab-coloured, but presently a golden belt of light, 
growing momentarily broader, showed on the horizon, and the cloud passed away, leaving us once again in cold, blue weather.

After lunch we returned to where the stag was lying, and Jack and I had just opened our knives to take off the head and neck-skin, when I spied a number of deer across a low valley to the north, moving along the hillside fronting us. We had a good look at them, and counted a score or more of does, and no less than four stags, all seemingly with good heads.

We followed them at once. The approach, owing to the position of the does, was awkward, but a good deal comes to him who waits, and finally we succeeded in crossing the valley unperceived and crawled in among some boulders about two hundred yards from the four stags, all of which were lying down. We had hardly arrived there before five does and a young stag came up over the shoulder of the barren and passed along within twenty yards of where we lay. This party, however, after giving us an agony of apprehension lest they should lie down between us and the large stags, fed gradually away from us until they disappeared.

We now carefully examined each of the four stags. All carried good heads, the best displaying, as far as I could judge, upwards of thirty points. Meantime, a fifth stag that had hitherto remained hidden, having probably been lying down behind a clump of juniper, emerged into view and began to make straight for the spot where we were concealed. His head was distinctly superior to that of any of his four companions, and I had ample opportunity to inspect it while he came slowly towards us. The antlers, it is true, were not very large, but exceedingly symmetrical, the bays being particularly fine and curved inwards. I reckoned that he carried thirty-five points, more or less, but quite possibly more. 
The wind was so strong that we were able to indulge in a council of war as to whether I should shoot him, a course which Jack strongly advised. However, in consideration of the splendid stag I had already secured, which had looked about half as large again as this one, I finally decided to pass him, especially as he appeared to me to be a young animal, despite his fine horns. We watched him for upwards of an hour, and once he was within sixty yards of us. All I can say is that some day that stag will carry a head worth travelling a long distance to obtain.

At length we crept away and retraced our steps to the big stag, and when we saw him again Jack agreed with me that I had done well to leave the thirty-five pointer. Having finished the skinning, we set out in the direction of camp, but had not gone very far when we saw more deer to the eastward. As before we stalked them, and as before we got very near, only to find, however, that the best of them was inferior to the young stag I had spared earlier. So we started once again for camp. I do not think the recollection of our walk of that evening will ever fade from my memory, and I make no apology for endeavouring to call up the scene before my reader's eye. It was one instinct with the spirit of Nature as she reigns among the marshes and barrens of Newfoundland. The wind was blowing out of a stormy sunset, swaying the dwarfed trees, sweeping over the morasses, now red and sulphur yellow with their autumn tints, and over isolated ridges of barren where dark crags stood up among the reindeer moss. All around the circle of sight companies of deer were moving, and as we doubled a curve of wood one fine young stag with red horns caught wind of us, bounded into the air with fear, and fled snorting; then for a moment he halted on the darkening sky-line, horns, head, and great white mane outlined. We tramped on, and soon the dusk fell, and presently through it we made out the flame of the birch tree logs of our camp fire, and 
arrived there to find that Frank and Arnold had returned.

Owing to the necessity of fixing and cleaning the head-

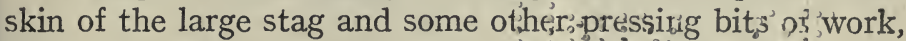
we could only make time for half 'a day's hunting on the following afternoon. We set out.about bre o. abock in a westerly direction, aiming for a locallty 'known às Ayres' Marsh. I had now set my standard very high, having made up my mind not to fire at any stag unless he carried a really remarkable head. The sun was shining through snow clouds over the wide marsh, making some of its pools glow to gold and crimson. Many companies of deer were in sight, some blurred and in shadow, others gleaming snowwhite in the brilliant breaks of light.

Our sport on that occasion does not demand any detailed description, consisting as it did of several stalks and a great deal of observation of distant stags through the telescope. We did not see anything "worth giving a gun to," as the Newfoundland expression has it.

Those were splendid days, their pleasures rendered the more vivid by memories of hunting in less favoured countries. Early in the morning, while the wood in which our camp lay was still an etching in black-and-white, the men were stirring, and soon the warm and cheerful camp fire would be crackling at the mouth of the tent. Followed the sound of Frank's footsteps as he crunched down to the lake edge through the frost and light snow. Then the kettle was boiled and a cup of tea made; after which I rose to complete the rough toilet of the woods before breakfast was announced to be ready.

On one occasion, however, this routine was altered. I had just been awakened by hearing the men moving about the fire, and Frank was in the act of pouring out my morning tea, when there was a sound of running footsteps snapping through the frost, and Jack burst through the trees. 
"There is a big stag, Mr. Prichard, crossing the 'mesh'!"

We were at this time encamped in a drogue of considerable site that reacherl Hown to the shores of the inevitable "pond." "All about it lay' a wide network of marshes much grown over'with' that wonderful soft reindeer moss and patched with coarse, yellowish grass.

"Stag's nearly past," added Jack, panting.

No time remained for dressing, so, pulling on a pair of Eskimo boots and a coat, in the pocket of which were some cartridges, I picked up the Mannlicher and followed at speed in Wells' tracks. We were soon at the outskirts of the drogue, and there, sure enough, in the wake of a band of does, was what appeared to be a fine stag.

As far as my experience goes, there are few things harder to judge at a distance than the size of a caribou head. For, firstly, antlers are likely to look very much larger carried grandly on the live animal than they sometimes turn out to be afterwards, when the deer lies on the ground: secondly, the angle at which one happens to view the head is a matter of importance, for it looks infinitely better from some points of view than from others.

The stag I am writing of seemed a very fair one; the wind was favourable, the only difficulty being the fact that he had already passed and was travelling at good speed over the moss and grass. We waited until he was screened by one of those small spinneys to which the stalker in Newfoundland owes so great a debt, and then we commenced to run. Owing to my having had no time to put on the stockings and vamps that are worn with Eskimo boots, these latter were very uncomfortable, and finally came off in some soft ground, sending their wearer head-foremost into a shallow hole full of ooze!

But to return to the day's routine. After breakfast was over I usually took my rifle and, with Jack or alone, 
set forth and spent the day hunting, sometimes seeing the stags on the open barrens, sometimes following them into the woods, in the sunny spaces of which they loved to lie and enjoy their rest. At midday we had our lunch of tea, bread, and smoked trout, and then hunted till dark, often making our way back to the camp by moonlight, to find the evening meal waiting for us by the fire. After that came successive pipes, the forecasts, meteorological and otherwise, for the morrow, then the sleeping bags and splendid, dreamless sleep.

The 3oth of October was another of my best days, for I met with numerous squads of deer trooping southwards. During the middle hours of the day these deer lay down among the patches of wood which surround Island Pond. Some description of the place is necessary. I cannot say how wide or how long this pond may be, for I never had a full view of it, part being always hidden by the trees clustering upon the many islets which, as in the case of nearly all pieces of water in this district, dot its waters. On the day I write of it was covered with a thin sheet of ice. The morning turned out fine, cold, and invigorating, and we were early away from camp. We walked some miles in a northerly direction, passing the spot where we had killed the big caribou two days before. On this occasion we did not see any stags until we were some three miles from camp, when with the glass we descried a pair of antlers moving above some bushes on the sky-line. The animal to which they belonged was evidently feeding, while between us and him lay a valley and a rise covered with woods. He was on a barren beyond these, and was sheltered by some small spruces that prevented our getting a very good view of him. So we descended into the valley and found a deer-path leading through the trees and glades. This we followed, and were cautiously crawling behind the spruces when the stag nearly ran into us as he came mooning along the very 
track we were on. He carried a fair head, but one brow was very poor, so I passed him, as well as two smaller stags.

We now climbed an eminence that commanded a stretch of likely-looking country, all barrens red with moss and patched with trees. Here we sat down and kept a good look-out. Shortly we saw the white shine of a deer's neck moving among some trees ahead of us. Taking advantage of the fact that we were well screened from sight, we ran across the intervening spaces and lay down in a thicket.

I must say here that, in my opinion, more caribou are lost through "pottering round" than in any other way. If you watch a stag cross your track, you see him leap up into the air and he is gone for ever ; or let him get the wind of you a mile off, and your chance is generally over. On the other hand, the eyesight of the caribou is poor. Midway between his sense of smell and power of sight comes his hearing, which is neither very good nor very bad in open ground, though earlier in the year he is a hard beast to kill in the green timber.

But to return to the stalk. We were still lying in the bush when, about two hundred yards away, a doe, old as the damsel of the evening star, came into view, followed at no great distance by other does. Behind them the bushes parted and gave up an old and ragged stag. The whole party passed along quite close, not a hundred yards from us. The old stag had a good wild head, but the left top was represented by a single jagged, broken spike, so of course I let him go in peace.

All the morning we loitered among the barrens round Island Pond, and saw two or three more stags, but none worth shooting; indeed, I had made up my mind that nothing under forty points, or its equivalent in weight or length, should tempt me.

At last we went to the edge of the water and boiled our 
kettle and ate our bread and smoked trout. While we were doing so a heavy fall of "sleepy snow" came on, and the bad weather looked as if it had set in for the day. But it proved better than we hoped. When the snow ceased we moved on, but presently took shelter again. By this time it was growing late, and as we were six or seven miles from camp I was about to suggest that we should turn our faces towards it, when Jack proposed going to the brow of the next rise and having one last spy round.

Over the rise we saw eleven does, one small stag, and another partially shut in by scrub. We looked for some time with the glass, but could not get a satisfactory view of this stag, when a third, which had been lying behind him, rose and thrust out his head between the spruce boughs. A glance showed it to be a magnificent one. He gradually came out and lay down again in the lee of another cluster of spruces, giving me the chance of examining him more closely. Through the glass I could see that he had, at any rate, one very large brow. Then he raised his head and showed great palmated bays, a large curling spike behind each. He was of a peculiarly white colour, with antlers of a much lighter red than common.

I decided at once to shoot him if I could, which seemed very doultful, as he was not favourably placed for stalking ; besides which a young stag and two does had moved along and lain down on a hillside about one hundred and fifty yards to our right and commanding our position among the cranberry roots. We were not more than two hundred and fifty yards from our quarry, but he was lying down in such a position that the only chance was a shot at his neck. About eighty yards from us, and nearer the stag, stood a thin cluster of junipers, and to this I crawled across a very wet swamp. Again I spied through the telescope, and was confirmed in my opinion. The stag carried a glorious head, furnished with a forest of points. 
A few flakes of snow came floating down, and I began to wonder whether it would not be wiser to take a shot from where I then was, but decided against doing so as my hands had almost lost feeling, owing to the long, cold crawl through the marsh. Between me and the stag, but partly in view of the young stag and does, was a ridge with little rising hummocks. I crept slowly to the shelter it afforded, and, having rubbed some warmth into my hands, prepared to fire. I was afraid to make the stag stand up, as he had cover on all sides of him, so I had to shoot him as he lay. He never moved at all, for the bullet, entering his neck, severed the spinal cord. He was a truly splendid fellow, carrying forty-three points, a white stag with a brown back, but unusually white face, ears, and mane. I found a small abscess in his forehead, caused probably by the horn of a rival.

With the death of this stag I had killed the outside number allowed to the holder of an ordinary licence, but finding myself in the centre of the migration I resolved to remain a few days longer and make use of the extra permit kindly granted me by the Government. On the following day, therefore, we broke camp at Doctor's Pond, where we had been so fortunate, and moved on in a westerly direction to the head of Island Pond; there we camped in a drogue of spruce which stood in a dominating position.

At this time, and during the rest of my stay in the country, I saw deer in great numbers every day. At first I counted as accurately as I could, but later I came across so many that I only numbered the stags which I clearly distinguished to be shootable.

There seems little reason to doubt that from the 27 th of October to the 5 th of November I was in the middle of at least a portion of the migrating deer. The following is the table of the caribou I saw on the trip :- 


\section{A FALL HUNTING TRIP.}

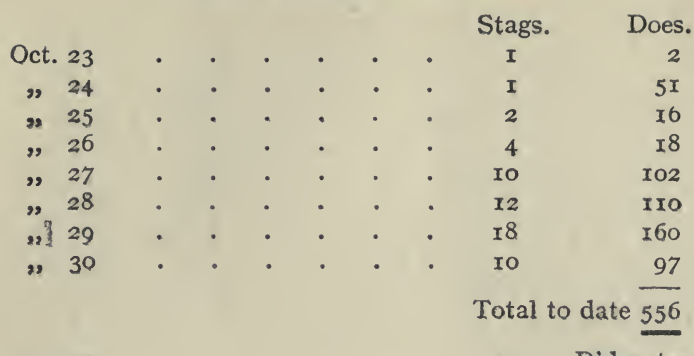

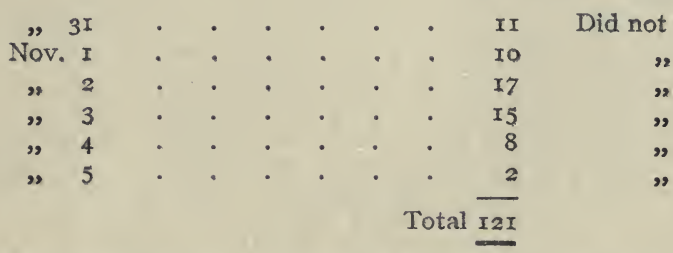

Speaking roughly, I should say that I saw during the trip at least I,500 does, as on the last day of October and the first three days of November I sighted them in such numbers that I had to give up the attempt to keep count. I afterwards learned from Jack Wells, who was in the country again late in November, that even towards the end of the month the deer were still there, though they were less numerous.

Notwithstanding that the general trend of the movements of the deer was westerly, there was no very decided, or, rather, direct, progression towards that point, the caribou wandering about in small parties of from three to six-and-thirty, which was the largest number I counted together. No doubt in that year the herds " took a shift," as my men called it, as neither before nor since, within their experience, had there been such an invasion of the Terra Nova country.

I am tempted here to give a short extract from my diary of the days that followed.

"Nov. I. Last night a great display of Northern 
Lights. Hunted to-day towards Deer Lake * Narrows, and saw ten stags, two of which had lost one horn, but one of them still retained a stump which was about four inches long. The morning was sunny, but in the afternoon, just as we were spying some deer, a mist came driving up before the southerly wind. I had my glass at the time on a one-horned fellow-not many points, but a very large and heavy stag. He vanished into the mist. During the remainder of the day it was too thick to see much.

"Nov. 2. Went round crossing Deer Lake Brook and up on a high marshy barren, which seemed to stretch for miles to the north, full of black morass. Snow and sleet driving before a heavy wind. Saw many does and seventeen stags, none particularly fine. The other side of Deer Lake the country seems to be all upland marshes and woods, that is before you come up on to the 'big country' that lies beyond it. At this time of year the stags seem to prefer the hard ground, the rocky, mossy barrens which Wells calls 'sandy ridges.' I do not therefore think the other side of the lake would be very good ground at this time of year.

"We then visited the barrens north of our camp; after a long hunt, saw a stag with curiously deformed antlers, no bays, but, as it appeared, two separate horns growing like a $\mathrm{V}$ almost from the coronet. While we were watching him a doe suddenly dashed into sight, followed by a stag with what looked like a head full of points. I thought him very good, and killed him as he galloped by at about one hundred yards. Thirty points only, but a very pretty head.

"Nov. 3. Hunted towards John's Pond, and walked about twenty-five miles. Saw fifteen stags and the largest number of does I have yet seen in any one day. I think

* Mr. J. G. Millais was the first sportsman to visit this lake, which has since been named after him. 
the really fine stags are very rare, one in a hundred or so. Cold, cloudy weather. All this time, although I have seen so many deer, I have observed practically nothing else on the barrens. Only one fox and one willow-grouse."

The next day, the $4^{\text {th }}$ of November, was my last full hunting day, as I wished to catch the next fortnightly mail to England. Jack Wells and I made a start in the rain long before it was light enough to see. I had decided to hunt the country on the southern side of the lake, which we had spied from across the lake on the previous day. Although the telescope had not shown much of the kind of ground which the stags at that season seemed to prefer, I fancied that the caribou, after passing through the woods near the lake, might be found travelling across the open marshes; and in this supposition we shortly proved that we were not mistaken. To quote Jack Wells, the country was "fair tore up" with deer-paths, and as soon as it became light we began to see deer in small parties, all heading west over the marsh.

During the morning and afternoon we sighted six stags, all distinctly shootable beasts, but none with a head as good as the poorest of the last three.which I had shot. Indeed, it was not until within an hour of sundown, and when we were many miles west of the camp, that we saw through the telescope a stag that appeared to both of us to carry excellent horns. But the difficulty of judging a living caribou's head was brought home to me once more on this occasion. I first spied it at a distance of about five hundred yards, and through the glass it struck me as being most generously palmated, for we were not able to see daylight between brows and bays.

The stalk was a long and interesting one, made somewhat difficult by the direction of the wind and several very watchful does. I at length reached a spot within one hundred yards of the stag, which was lying down 
facing me. At this angle the head looked so light that I decided not to shoot, and had already rejoined Wells, when one of the does took fright and ran off, followed by the stag. Broadside on, the horns looked better than ever. I had put my rifle over at safety, so that it took a moment or two to rectify this, as well as to find a clear place among the cover through which to shoot.

By this time the stag was some two hundred yards away, splashing across a marsh with the water flying all round him. At the shot, however, to my delight he staggered, slowed to a walk, and presently stopped altogether. As I was sure that he was mortally hit, I very foolishly attempted to approach closer, for I had but a couple of cartridges left-several having fallen from my pocket during the stalk-with the result that he began to move off again, and in doing this he crossed our wind, whereupon his fresh alarm seemed to give him an access of strength. Luckily for me he chose to disappear behind a long tongue of woods, and by dint of running I was able to arrive just in time to salute him with another bullet as he ran clear of the trees. This shot broke his back, and we were soon beside him. I now saw that there was only one bullet in the animal, the first having struck his horn and stunned him. The peculiar shape of his antlers, which curved forwards and downwards in a very unusual fashion, bringing the whole mass of horn together, explained the impression of excessive palmation that we had at first observed. The trophy was, however, a very beautiful one of thirty-one points, so that the chance shot was, after all, a matter for congratulation. With the death of this stag I finished my hunting for the year.

On this trip I was extremely fortunate in striking as I did the great scattered herd of deer as they were travelling south. I thus had the most acceptable opportunity of studying and watching them for hours at a time. By 
climbing a tree or mounting to a point of high ground it was possible to spy over a great expanse of country, and, having found a company of deer, to follow and stalk any stag which seemed to be worth the trouble.

I suppose I stalked quite forty stags to within range, and it was frequently the stalk that did not end in a shot which proved in its details to be the most interesting. With a reasonable time to spare, seeing stags almost every day and stalking them, even if the stalk rarely ends in a shot, what can a hunter want more? Of course there is a great temptation to shoot-first, because caribou heads are, as I have said, hard to judge, and also because it takes some self-confidence and belief in one's luck to allow (say) a thirty-pointer to depart when within easy range in the hope that the next day or the next week will produce a head of forty points.

Central Newfoundland is a wild country enough, and a country that grows upon one. The term "barrens" is liable to give a wrong impression to those who have never seen them. The barrens are, in their way, most beautiful, with their delicate general colouring of pink, sulphur and brown. Imagine the open uplands tinged with red and white and yellow mosses and red-leaved shrubs, through which scores of boulders thrust out their dark heads, and here and there patches of evergreen spruce, pine, and black firs showing every twig against the pale blue of the sky. It is, without question, a fascinating country that tempts one to return again and again. 


\section{CHAPTER V.}

OCTOBER AND NOVEMBER HUNTING NEAR MIDDLE RIDGE.

THE shooting season of I904 I had originally intended 1 to spend in Canada in the hope of securing a moose, an ambition that I had entertained for a long time. Eventually I changed my plans for various reasons, the chief among them being the wish to return to Newfoundland for the purpose of hunting in the country which lies in the neighbourhood of Middle Ridge, a region which, I believe, had never been penetrated save by the Indians. It happened that early in I904 I mentioned this district and the good sport I had enjoyed on its confines to Captain E. G. Wynyard, who wished to accompany me if ever I revisited it. I therefore gave up the idea of moose for the time being and commenced to make arrangements for a return to Newfoundland by buying, through Mr. Henry Blair, of Water Street, St. John's, two excellent canoes.

I also wrote, through the same admirable agent, to try and engage the same men who had accompanied me in the previous year, and was glad to find that Jack and Frank Wells were available; but George Arnold had left the island for the summer, having gone with his sons on a cod-fishing venture to the Labrador coast, and we therefore engaged Walter and Sam Dewey, of Glovertown, Alexander Bay. Walter, a man with the excellent quality of keen sight, had several times filled the position of "second guide" to hunting parties, and although he had never 
gone on a protracted expedition into the interior, was nevertheless well used to camp life and proficient in finding his way, packing, and other tasks, which make a capable woodsman. The brother, Sam, was some years younger, in fact little more than a youth.

On the Ist of October Captain Wynyard and I left England on the Allan liner Carthaginian, and after a fair passage arrived in St. John's, where we hurried through the necessary preparations, and in the early morning of the I4th the Newfoundland express put us down at Terra Nova, where our men were waiting for us. At this place I found, also, an old schoolfellow, Mr. I. H. Simon, in camp, he having, on my recommendation, employed Jack and Frank Wells for the earlier or September season. Simon, though he had seen very few deer, not more, if I remember rightly, than five shootable stags, had nevertheless killed three good heads, the best being a very heavy one.

He gave us the news that a party of American hunters encamped close by were going to hunt what is known as the "middle country," a district lying to the east and south of Island Pond. The leader of this party had just returned from Nova Scotia, where he had been after moose. On hearing that these gentlemen intended to hunt the " middle country" we were well content, as although we purposed ultimately to cross towards Middle Ridge, yet the ground between us and that tract had been so full of caribou in the previous November that I should have been sorry to share it with any other hunters.

The next day we put all our outfit aboard two flats and the canoe, and started up the lake under a downpour of heavy rain. Very soon the wind rose to such strength as to render the crossing of Terra Nova Lake in our deeplyladen craft a matter of question. At last we decided to camp and spend the remainder of the day in going through 
the list of our provisions and arranging them in suitable packs.

On the I6th, the wind having fallen, we proceeded upon our way and slept that night at my old camping place at Butt's Brook. When I last saw it, the year before, this spot had been very beautiful, but I now found to my disgust that a forest fire had devastated the woods, while the underbrush had been reduced to black sticks, which made it impossible to walk in any direction with pleasure, the more especially as the charcoal stained one black from head to foot. The limit of this fire was not reached until we came to Beaver Pond on the high country.

From Butt's Brook to Millais Lake it was necessary to portage both canoes, for we had brought a second collapsible canvas canoe with us. All over this country where previously I had had such magnificent sport we failed to see a single deer, until, on October 2oth, as Wynyard and I were crossing a barren to look at the skeleton of my largest stag of the former season, a band of seven does, escorted by one small stag, came into view round a drogue. At once they got our wind and dashed away. About four o'clock we reached Simon's furthest camp, and, leaving the men to prepare for the night, Wynyard and I walked out, thinking it might be worth while to look at the carcases of the deer Simon had killed, in case any of them might have received a visit from a bear, for some few of these animals are to be found among the berry-covered barrens. After visiting the carcases without success, we were returning to camp in the late dusk, when I caught sight of a stag approaching. We lay down, and the stag climbed a knoll within eighty yards of us, where, outlined against the sky, he showed splendidly-better, indeed, than he deserved, for he carried but a slight head of less than twenty points. We were uncommonly glad to see him, as, according to reports, he certainly had not been there 
when Simon had been hunting, so that his presence augured that the migration had begun and that we might expect the main body of stags at no distant date. The next day, the 2Ist of October, was the opening day of the second season, and Wynyard and I, accompanied by Jack Wells, were off early. The weather was beautiful, and even rather warm. Before long we reached the series of high barrens above Millais Lake, and here we were destined to witness a really fine spectacle.

We were lying behind some spruces watching three stags, one with well-developed bays, that we had stalked, when an old stag, with a band of does following him, came up out of the Island Pond woods. Immediately they appeared in view the stag with the large bays galloped out across the marsh, challenging the newcomer. The master stag of the harem was nothing loth to try conclusions, and advanced at once to the combat. Both animals uttered a kind of coughing grunt as they closed, and were soon hard at it, clashing their antlers together, measuring their strength as they twisted and strained in the struggle to push each other backwards. The battle lasted some minutes, the stags engaging and disengaging more than once, as they were very equally matched. It was really a magnificent sight, and we were able to enjoy it at no greater distance than one hundred and fifty yards. The does seemed to take a very lukewarm interest in the fight; some of them went on feeding with indifference, and two or three strayed off towards the other two stags, who maintained a pointedly detached position afar. Wynyard and I wanted to bet on the result of the battle, but as both of us fancied the chances of the same stag the idea fell through.

The old stag, on whose antlers I thought I could make out twenty-one points, was a very heavy animal, exceedingly light in colour, while his opponent was markedly darker and certainly possessed the finer head. A $t$ length, 
after a protracted period of straining, for in the contest, which resembled a wrestle rather than a fight, there were no rushes, but rather a careful locking of the antlers, followed by a strenuous shoving match, the old stag seemed to get his horns against the forehead of his rival and began to bear him back. Then suddenly the battle was over, Big Bays gave way, leaped clear, the old stag made one violent pass at his enemy's flank, and missed, and then Big Bays was in full retreat. The old stag stood for a moment rejoicing in his victory, then, possibly feeling that order must be restored, he rounded up his harem and passed away across the hilltop. The whole incident was one we were delighted to have seen. Both of us were struck by the lack of agility displayed by the stags, the battle being, as I have said, purely a shoving match.

Each time the stags engaged, however, the antlers elashed together, producing a loud sound. It seemed as though the massive caribou heads are difficult weapons to manipulate, and I can very well understand that a head with large and beautifully palmated antlers may be inferior as a weapon to a lighter and more easily wielded growth.

I cannot think there is much danger to either combatant, except at the moment of defeat, when the victor makes his rush at his opponent's flank. Indeed, it is probable that nearly all the encounters which end fatally do so because of the locking of the antlers, when, unable to free themselves and consequently unable to feed, the unfortunate combatants starve to death. It is by no means an uncommon thing to find dropped horns interlocked in this way. But, on the other hand, all horns sold interlocked need not necessarily have been so locked in fight, for with a little force and the help of the fire and manipulation it is said to be possible to lock two pairs of antlers artificially, and $I$ believe cases of this lind are not unknown. A good 
quartette of locked antlers are readily sold for as much as $\$ 50$.

After the battle was over we went on our way and hunted down towards the lake, and while we were watching the large marsh near the lake head two stags began to cross it in our direction, but neither was worth shooting, and although all day long we continued to see both does and stags in some numbers, none of the latter pleased us, and we ultimately got back to camp with clean rifles.

In the course of ten hours we had seen no. less than eighteen stags, and were naturally in good spirits; nor had we any doubt but that the next few days would bring each of us, as Wells said, "alongside" the big stag we desired.

On the following day Jack and I went a long distance to the north. During the forenoon we heard several shots, and were quite sure that Wynyard had been lucky in his hunting, when all our hopes were destroyed by finding the newly-severed head of a stag and the place where the body had been butchered. The head was a small one, carrying only fourteen points, and its presence could only be explained in one way-that a party of meat-hunters were abroad, and to judge from their tracks there were more than a few of them. Later we came upon the remains of a doe, which, like the stag, had been killed on the previous day. As we were certain that no party of hunters had come in by way of Terra Nova, we were rather at a loss to account for the presence of these people, and were inclined to believe they must belong to a camp of surveyors. But we were utterly wrong in this surmise, as Wynyard met three of the party that day and found that they were settlers from Gambo, thirteen strong as to numbers, and that they had for the last nine years come to the Millais Lake country to shoot their winter's meat. Of course their presence was as unwelcome to us as it was unex- 
pected, and but for the fact that they were already preparing to leave we should have been forced to move away, which would not have suited our plans, as we had not yet been able to bring up all our outfit and supplies. However, there was the long stretch of country towards John's Pond and on the south side of the lake, that they had not visited, and that would afford us excellent hunting until the men brought up the canoes which would enable us to push forward across the lake.

In consequence of this meeting with the settlers we could not help being reminded of the somewhat appalling fact that the thirteen men from Gambo possessed the legal right to kill sixty-five deer. In connection with this we recalled the bands of Norwegian hunters, who are each allowed to kill three reindeer, and who club their rights and used to pursue the few surviving herds of the Dovrefjeld with Krag-Jorgensen repeating rifles, opening fire at immense ranges and firing volley after volley when the deer ran together, and continuing to shoot until the herd had fled out of sight. This state of affairs has, however, recently been rectified in Norway by the passing of a law which forbids the use of a repeating rifle against reindeer, and further regulates the bore of the single-cartridge weapon which is permitted. The second part of this law rules out the Krag-Jorgensen and other small-bore rifles.

Of course I do not for a moment suggest that the Gambo party would, even if they could, have pressed to its limit their privilege of shooting sixty-five caribou among them; the consideration alone of being so far from the railroad would have prevented this, as it would have been impossible to handle such an amount of meat without some means of transit other than men's backs. But, seeing the harm that may quite legally be done by such large parties, I think a law prohibiting the hunting of caribou by a company of greater strength than six members may some day 
be worth the consideration of those in power in our oldest colony.

Late that same afternoon, as we were bound for camp by way of the head of Island Pond, we saw a good-sized stag, which we did not disturb, and not long afterwards we heard some deer moving in the water. Creeping down, we soon came in sight of two does, one with a maimed shoulder, and a stag. The stag, though partially hidden by the trees, seemed to show a fine head, and we spent the better part of half an hour trying to get a good view of him. The stalking of that stag has, for some reason, always stood out prominently among my memories of Newfoundland. The does, and more especially the maimed doe, were extremely watchful, so much so that we had a good deal of trouble to get within two hundred yards. At that range I took a careful look at the stag with my telescope, and made out that he carried good tops and bays and one very large brow.

I was, however, particularly keen just then to kill a stag with two equally-developed brow antlers. At the distance it was impossible to see whether the big fellow carried one or two, so I decided to try for a nearer view. Since he had left the shelter of the junipers, where I first saw him, he had been standing quite still, but no sooner had I crawled well out into the open than he began to feed, moving as he did so. In this way I must have stalked him for quite two hundred yards, until I noticed that he was appreciably increasing the distance between us. The does, who had also become invisible for a time, now fed out on to the ground which separated me from the stag. At length I gained the cover of a dwarfed spruce, and, after lying there for some minutes, was relieved to find that the does were moving away at right angles; the stag did not seem to notice their departure, but remained at the edge of the lake. Taking advantage of this, I crept 
along some rocks directly above him, and finally got within sixty yards, where, from behind a big boulder, I was able to count his points through the glass with some accuracy. He carried four points on each top, six and four on the bays, two at the back of the beam, and on one brow I imagined that I could make out ten and on the other four points. Besides these there was one very clearly defined extra point above the right brow.

Now it is undoubtedly a very fine head on which one can count thirty-five points at sixty yards, but, as I have said, I was eager to secure a pair of even brows, and no doubt my good fortune during the previous year had given me an exaggerated idea of the trophies I might expect to obtain. So, in spite of the urging of Jack Wells, who had joined me, I put off shooting. Meantime the sun went down behind us and the moon rose. It was a perfectly still night, not a ripple stirred the silver water of the pond on which the little wooded islands showed like blots. We must have remained for a very long time behind our boulder watching that grand stag. Presently Jack besought me with many signs to shoot, and was much upset by my refusal, and ultimately we crept quietly away, and, as we rose to our feet in the moonlight, on the barren above I could hear the stag walking through the water. "Why didn't you give a gun to he?" Jack asked in accents of deep reproach. I excused myself on the score that he was not as good a stag as those we had shot during my former season in Newfoundland. Jack pointed over the barren. "You remember that thirty-five pointer you let go up there last year? There was a better head on he than on two you shot after." I had to admit that was so. "Like as not, that stag you let go is the best we'll see this trip!'

With which cheerful prophecy we went on our way to camp, where I found Wynyard, who had seen little save the men from Gambo. 
The following day, being Sunday, was to be a day of rest, but when I woke in the morning, rather late, I found that the younger Dewey had set out before dawn for Beaver Pond, where we had cached the collapsible canvas canoe on our journey down. It rained all the day with a depressing persistence, and towards the afternoon a dense mist obscured the country. The rising of this mist caused Walter Dewey some anxiety, as his brother had had practically no experience of the woods, and had only been over the route through which his way lay when he travelled up with us ten days before. When the day closed and darkness came on we all began to share Walter's fears, for it certainly is easy to lose one's way in thick weather, and once lost an individual's life often depends upon his temperament.

Perhaps foremost among the subjects which are discussed with perennial interest by those who live close to nature is the position of the man who loses himself in an uninhabited tract of country. To be so lost is an experience which most people who have spent any considerable portion of their lives in forests or in wildernesses have at one time or another undergone. The moment at which a man first realises that he is lost is, unluckily, in some cases a moment of panic. In blind haste the unfortunate individual rushes off, generally in the wrong direction, and, driven by his nameless terror, travels over long distances, exhausting himself uselessly. Nine out of ten tragedies of the woods have been the direct result of giving way to this almost uncontrollable impulse; in many a case some inexperienced hunter or prospector, even though carrying a rifle and the other small impedimenta without which no one should ever leave the main camp, has hurried on and on, deeper and deeper into the bush, using up his strength and finally dying of starvation, when the knowledge of a simple rule or two would have saved his life. Of course, as 
all with experience know, the one and only thing to do is to light a fire on the spot and to sit down and keep warm beside it until daylight, when a man's comrades, who have missed him and are on the look-out, can see the smoke and walk him up. It will be understood that to an excitable nature the moment of panic is hard to conquer and a masterly inactivity is difficult.

Even an expert woodsman may be lost, for instance, under conditions of thick weather, whether of mist or falling snow, but such a one will know how to retrieve his mistake in one way or another. Perhaps I may be pardoned for repeating the old story of the Indian and his white employer who were lost. After wandering for a long time and failing to find the camp they had left in the morning, the Indian threw down his grub-bag and gave up the search. "Indian lost," taunted the white man. "Oh, no," replied the Indian; "Indian not lost, camp lost." The inference is plain.

As I have said, the subject of being lost is one often talked of round a camp fire, because the contingency is never too remote. A company of woodsmen and trappers, when discussing the essentials of life in such a case, chose them in the following order :-

I. A rifle and cartridges.

2. Matches.

3. An axe.

After that, opinions were divided between a cookingpot, tea, salt, tobacco, and a blanket, but these latter articles were generally acknowledged to be luxuries, not necessaries. It is easy to imagine the case of an expert in the northern forests who is either lost or is unable to reach camp on a snowy night. From pushing his way through the thick-growing trees, he is wet to the skin, and darkness is upon him. The moment he determines to make no further effort he begins to look for a spot in which 
to pass the night. The wind is blowing bitterly cold; he therefore chooses a solid clump of trees which will break its force, and in the shelter of which only a few of the snowflakes will reach him. Then he does not at once light a fire, but collects sufficient wood, dead logs and fallen branches, to last till daylight comes again; for the old hand knows better than to have to turn out from his snug lair at three o'clock in the morning, may be, to bring in fresh fuel. He strips the bark from a birch, putting some of the dry inner layers into his pocket to start his fire, and he gathers a large quantity of boughs, of balsam if he can get them, to make his bed and shelter. Having transferred these to the chosen spot, he clears away the snow from it and then piles up some tree-trunks to the windward, and afterwards makes a second rampart of logs opposite to the first, against which to build his fire. However bleak the night, a fire, carefully fed, is quickly blazing, through the flame and smoke of which he passes his balsam boughs to dry them for his bedding. Branches skilfully laid make a mattress as springy and comfortable as any one could desire. The last thing is to spread the fire into a long blaze, longer than himself, so that he may feel its heat through the whole length of his body and limbs. Wood to replenish it is placed within easy reach, and after eating food, if he is lucky enough to have any with him, he can lie down opposite his seven-foot fire to enjoy a night of warm sleep even if the thermometer marks degrees below zero.

To light a fire with a cartridge, in the absence of matches, the bullet must be removed and the shell filled with some inflammable substance that will hold in the powder. Fired at close range into a properly prepared pile of tinder this will usually ignite it, especially if there be birch bark amongst it. Without birch bark the difficulties are much increased if the weather be wet, for the heart of an old log or limb 
of hard wood whittled into chips makes but a poor substitute.

Newfoundland, it is true, is far from being a difficult country in which to find one's way. On the other hand, it contains several thousand square miles where a man may be lost very effectually. In fact, if Sam had managed to wander off the trail there might be only a risky chance of finding him again. Yet, but for Walter's obvious fears, it would not have occurred to me to be alarmed, but his state of mind was infectious, so that when dark finally fell I would have given a good deal to see Sam walk up to the fire. We passed rather an anxious night, and it was arranged that at dawn the men should light a large smoke; but when the morning light began to show we saw that the whole face of the country was draped in a mist that was thicker than ever, and far from improved by a continual downpour of heavy rain. Through this Jack and Walter went off to Beaver Drogue in order to see if the canoe was still where we had cached it. The rest of us remained in camp and kept up a big fire, while all through the day. the mist and rain persisted without a break, rendering any attempt to go in search of Sam useless. It was only to be hoped that Sam had reached the canoe, otherwise he would be unable to find anything but berries to eat, as he started with only a knife. Had he carried a rifle there would have been little to fear. It was a relief when Walter appeared late in the afternoon with the news that the prudent Sam had been found, warm and comfortable, fast asleep under the canoe. I think that on this occasion the fears of our men made us unduly anxious, but, at the same time, in an uninhabited country the margin between safety and danger is always a narrow one, and we gave orders that for the future Sam was not to go far from camp without one of the other men.

On the morning of the next day we moved camp, chan- 
ging to the eastern shore of the lake, where Wynyard and I slept while the men went back to bring up more packs. Just behind the drogue of trees in which our tent was pitched stretched a large marsh, where during the previous season I had seen several stags. Near by grew a tall juniper, from the upper branches of which a very useful view was obtainable, for the marsh was a particularly promising place to watch, because it presented the only open ground for some distance, and would therefore probably be chosen as a crossing place by any stags that might be working round the lake head. But, although we kept a close watch, the only stag that appeared was a small one.

On the following afternoon Jack Wells and I canoed over the lake and camped at the Narrows, while Wynyard remained at the base to hunt the southern slopes, where I had killed my last stag in I903. It was agreed that he should join us at the Narrows on the next day. In the evening a fair stag crossed the lake, swimming from shore to shore, a distance of over two miles. Up to this time, although we had seen twenty-eight stags, neither of us had fired a shot, and I was beginning to think with sincere regret of the fine thirty-five-pointer of Island Pond. Frequently at this time, when Jack looked gloomy, if I asked him the cause he would answer, "That stag of Island Pond had a shocking head!" "Shocking " and "dreadful" are, curiously enough, two of the highest terms of praise that a Newfoundlander can bestow upon a caribou trophy.

We had had more than our share of rain up to this period, and I was awakened as usual on the following morning by the hammering of rain-drops upon our lean-to. I had opened my eyes, when I heard something moving near by on the isthmus of the Narrows, and, looking out, I saw a fine stag, accompanied by two does, staring at the camp. After a short interval I could have shot the stag from my bed as he moved round to get the wind, but the 
remembrance of the stag of Island Pond, which carried a far finer head, withheld me, and presently one of the does got to windward and the three instantly disappeared, with a tremendous splashing of water.

All day the rain held on, blowing up before a strong south-east wind; through which Wynyard and Frank arrived. But the morning of the 28th broke beautifully blue, and we crossed the lake to its western end. We now had all about us absolutely virgin country, and when Wynyard, who had walked round part of the way by the shore, joined me we spent most of the day exploring it. We saw but little sign of caribou, as the woodland was thick, so in the afternoon Jack and I climbed up through a wide expanse of green timber on to the high country, but had to return before we could examine it. That night we decided to separate, Wynyard taking the southern side of the lake while Jack and I, with packs, were to travel as far as we could towards Middle Ridge. This Middle Ridge, which may be said to form the backbone of the island, is not so much a single low range of hills as a series of undulating uplands covered with trees. At that time, to the best of my belief, no white man had ever set foot on Middle Ridge, though many had seen it, for it is visible for a great number of miles, presenting as it does almost the only recognisable feature in a broad landscape. We found some difficulty in carrying our packs through the dense woods that lie between the lake and height of land, but at length we took advantage of a marsh heading upwards. The rain of the earlier days had now turned to snow driven by a heavy wind from the north, and it was after a tiring pack that we at last put up our camp among an isolated group of spruces in the middle of a wide marsh. By the time this was done there still remained a couple of hours of daylight, which left us time to take a look before night closed in at the new country, in which we hoped to find evidences of a large migration, 
for time was growing short. November was upon us and the stags would soon be dropping their horns.

Although we had been covering much of the same ground where I had, during the year before, seen such numbers of deer and secured fine trophies, I was now much less fortunate. I saw no more than a quarter of the number of caribou, and the heads were disappointing, but this could partially be accounted for by the fact that the previous winter and spring in Newfoundland had been exceptionally cold and severe, and in consequence the antlers did not grow, in most cases, to their usual dimensions. But even in these "lean years," of which I904 and I905 are good examples, there are always a certain proportion of stags whose horns are so massive that they seem, in some degree at any rate, to defy the result of adverse weather. We began by making a circle to get the wind in our favour, and as we passed out from behind just such another clump of spruce trees as that in which our camp was set we saw before us an undulating upland covered with snow which had drifted among a dwarf growth of spruce and their kind. Just upon the hither side of the sky-line a little band of caribou were lying down. There were seven of them in all, and two appeared to be mature stags. Up to that time the necks of stags had always shone out white against the yellow of the marshes or the claret-coloured moss and leafage of the barrens, but the animals we were now looking at appeared of a dirty ivory against the pure background of snow. It was not until we had approached within shot that I saw that neither stag carried antlers of any great size. We were about to turn aside, intending to leave the animals undisturbed, when the tops of the horns of another stag rose over the sky-line. Soon the stag himself appeared, and after standing for a moment he began walking down towards us. Lying as we were in a patch of spruces, none of which were more than two feet high, we were nevertheless quite invisible 
to the stag, so that long before he was opposite us the telescope had been levelled upon his horns. They were very long and thin, rather of the Norwegian reindeer than of the caribou type. I was half tempted to shoot, as the head was more than a fair one, but the uncertainty as to whether the left horn, which was farthest from us, was as good as the right made me pause. In time the stag returned on his course and presently crossed within a hundred yards. It was now perfectly clear that he was not more than a five or six year old, so, giving up all thoughts of a shot, I spent the gloaming within a few yards of this beautiful creature, finally slipping away unnoticed and returning to camp full of hopes for the morrow.

Almost throughout the trip, as I have said, we had been the victims of a kind of weather which, more than any other, is unfriendly to the stalker. The days had been nearly without exception darkened by successive squalls of rain or melting snow, yet each evening it had blown clear and the nights had been frosty and starlit. In these circumstances we rejoiced to hear the wind roaring in the trees and shower after shower of sleet beating upon our lean-to throughout the entire night, for we made sure that morning would bring a change for the better.

This was exactly what happened. The sun rose unclouded and bright, and, stepping out of camp, we were at once greeted by a sight of the three stags which we had seen upon the previous evening. They were easily recognisable through the telescope, so we wasted no time in stalking them, but, taking a long cast to the northward, were soon able to see over a large extent of country, upon which, however, nothing seemed to be moving. The early hours of the morning brought no good fortune, and it must have been nearly midday when, in the hollow between two rolling hummocks, we came upon a large flat rock. The top of this rock formed a slight depression filled with shallow 
soil where grass and low shrubs were growing. To the northwest lay a huge marsh, in the centre of which a doe caribou with a comparatively large pair of horns was feeding. The sun had come out deliciously warm, so that Wells and I lay down upon the top of the rock and gave ourselves up to a desultory consideration of the big doe's movements. We must have been there half an hour before Wells suddenly said, "Look at the big stag. That is a brute." This again is one of the top notes of Wells' vocabulary of appreciation. I looked up just in time to see a large stag in the act of slowly rising from a depression fringed about with a growth of young spruce, where the nature of the ground had hidden him completely from our view. There was no need to take the telescope, as even at the distance which divided us it was plain that his horns were broad and heavy. Whether we should ever have a closer view of him was a question much more open to doubt, as he was standing in the very centre of the marsh and the wind was exceedingly unfavourable. There was but one thing for it, and that was to approach him from the farther side.

The surface of the country in most parts of Newfoundland, and more particularly among the bogs and marshes, is peculiarly ill-adapted to running, but as both deer seemed uneasy we endeavoured to make our circle at the highest possible speed. Certainly we covered our two miles round in fair time, and reaching the other side of the marsh we flung ourselves down for a moment's rest. On rising I found to my disgust that the wind had veered, and in order to make our approach we were forced to retrace our steps almost to the point from which we had started. Meantime, however, the doe had lain down, and the stag was feeding some two hundred yards behind her. Fortunately the two were nearly in a line with a long, low bank of moss which gave us a little shelter. The distance to the deer was fully half a mile, every inch of which would have to be covered 
by crawling. At length we arrived at the very limit of the little bank of moss and found ourselves confronted by a large bog-hole that lay almost flush with the surface of the marsh. As we paused here the stag approached the doe and prodded her a couple of times with his horns. She at once rose and ran about a hundred yards in our direction, when she slowed to a walk. It was perfectly clear that if she held upon her course she must soon come upon our tracks by the flat rock, when she would at once make off, taking the stag with her. We were therefore obliged to attempt the open stalk. During its course the rifle as well as ourselves became covered with black slime, and I was sorry I had not that morning brought the case; but in a country which is broken up by woods to a very great extent, as in Newfoundland, it is impossible to carry the rifle in its cover without risking the loss of an occasional quick shot. So by dint of tying up the action of the Mannlicher in a pockethandkerchief I attempted to prevent any untoward jamming accident. Luckily I was clad in brown clothes, which harmonised with the colour of the marsh, but Wells' dark coat was at times so much in evidence that I was about to continue the stalk alone, when the doe obviously made us out and sounded a warning. The stag ran up beside her and stared in our direction; then, as caribou sometimes will, he circled round at a trot in order to get our wind. This brought him at one point to within about two hundred yards, on which I threw the foresight upon his chest as he turned, and fired. He gave a couple of bounds and went off in a cloud of marsh water. Although I had heard the first bullet strike, I was about to fire a second shot, when he fell head over heels into a bog-hole, where little but his antlers and one hind hoof were showing above the mud by the time we ran up. It was necessary to make a little bridge of logs to the body before we were able to touch the trophy, which turned out to be rather past its prime. Never- 
theless the weight of the head made up for its irregularities, and we were glad to think that we had at last killed a stag upon those ridges of which both of us had been thinking for so many months.

After the day just described the wet weather, alas! resumed its sway, the winds blew more violently than ever, and, worst of all, rain once more took the place of snow, and for the following days and nights we were never dry. The deer upon the Middle Ridge country proved to be exceedingly wild, a fact which we at the time accounted for by concluding that they might possibly have been harried by wolves. This opinion was, however, later proved to be erroneous. The true reason is that Middle Ridge, as well as the burnt lands to the west of it, form one of the chief hunting-grounds of the Micmac Indians; indeed, the ridge itself is parcelled out into individual preserves and rigorously hunted. The chief of the Micmacs told me that a number of his people were camped in the Partridgeberry Hills near the source of the Gander in the previous September.

During the autumn months the Micmacs migrate to their hunting-grounds, where they trap a good number of beaver and lynx. They are a cheerful and improvident race. Why is it that the enchanting quality of cheerfulness is often linked with this correlative? With their old muzzle-loading rifles, an axe, a blanket, a box of matches, and a packet of tea, they habitually make long journeys, often crossing the island from the south coast to the railway. Although popularly supposed by the settlers to "kill all they can come up with," it is quite probable that they are far more economical of animal life than their white brethren. Among them some interesting customs still obtain. For instance, I have heard it said that no Indian hunter will ever kill a caribou stag without first whispering a short speech or prayer addressed to it, in which he regrets the hard 
necessity that compels him to fire the death-shot, and adds his good wishes for the welfare of the caribou in that land to which it is about to travel. This at least, if true, does not suggest the spirit of the reckless slaughterer.

After spending some fruitless days hunting the high ground we turned east and south, seeing stags almost every day and always stalking or attempting to stalk those we saw. None of them, however, carried a head to compare with the one I had already secured; so that night after night we tramped back to camp, tired and disappointed, until ultimately I gave up in despair and recrossed the lake.

I found Wynyard had shot an old stag whose horns, although heavy, had " gone back," for the animal must have been well past his prime. But on the 7 th of November Wynyard's luck came at last, and after an admirable stalk he killed two good stags, the better of the two having finer tops than I have seen on a live deer in Newfoundland. His success put us all in great spirits that night, in spite of the unending rain which continued to fall, as it had done for so many days, with something of the volume of a thunderstorm, till it seemed useless to hope for fine weather. For all that, on the 8th the morning broke clear, and Jack, Sam, and I started out early with three packs, intending to put in the last three days hunting from Selous' old camp on John's Pond; but though we set out in good time we were not fated to arrive there, as some two hours later, as we were carrying our outfit over the barrens, we came to a high, bald knoll, from the top of which we spied three does passing through a wood a mile away. As it seemed likely they would be accompanied by a stag, we put down our packs, and, leaving them with Sam, Jack and I started in pursuit. When we sighted them the does were moving at a fast walk, so we made a long circuit behind a ridge in order to head them off. As soon as we turned up wind and ascended the ridge we saw the white stern of one of them in a 
thick wood, and presently I thought I caught a glimpse of the top of an antler, but could not make quite sure. All the animals were moving, and as it was impossible to see more than ten yards in the thick growth we set off as rapidly and silently as might be to a spot ahead of the deer, where the wood seemed to be less dense.

Owing to the nature of the country and the continual necessity of fording streams and crossing flooded marshes, we were both hunting in sealskin boots, which are made by the Eskimo of the Labrador Peninsula. The soles of these boots consist of a single layer of skin and are as noiseless as moccasins, but the legs, which tie below the knee, being very full and baggy, act like a drum upon which the lower stems and leaves play a tattoo as one passes through them. I had, by ill-fortune, put on a new pair of these boots that very morning, as my old ones had been placed too near the fire and in consequence burnt. Now as we moved along the edge of a wood the hard new legs set up a disastrous tapping with the touch of every twig. We had to delay while I pulled the tops of my stockings down over the boots; this done, we were able to resume our stalk in adequate silence.

As we were hurrying along, a portion of a stag's antlers suddenly showed in a gap among the spruces. He had heard something and was evidently suspicious, as the antlers remained perfectly still, and by their angle the animal had raised his head to listen. From my position it was only possible to see that the left horn carried five points on the top. I was wondering what the rest of the horn was like, when the stag took a step forward preparatory to flight. This movement disclosed more of the horn, and as the view was highly satisfactory I fired at once. The Mannlicher bullet broke his neck. The stag, which had the smallest body of any I ever shot, proved to possess a most symmetrical and beautiful head of thirty-five points, the 
brow antlers being perfectly equal and fulfilling exactly the description of "hands clasped in prayer." It is singular how few caribou grow the brows evenly. There is no single specimen in the British Museum from Siberia, Canada, or Norway which displays this distinctive beauty. Nearly all Newfoundland stags carry two brow antlers, but one is almost invariably inferior to the other, that on the left being usually the finer.

I sent off Jack to bring up Sam and the packs, and on their return we camped in a drogue of birches not very far from the body of the caribou. While we were setting up our lean-to the rain began again to fall heavily, but as we had been walking up-wind we were able to light a fire without spoiling any more ground for hunting. It is astonishing how quickly one can light a good fire in Newfoundland, for quantities of inflammable birch bark are to be found everywhere. In a few minutes we had boiled a kettle of tea and were as comfortable as our soaking garments would allow us to be. The tea was hardly drunk before the wind shifted several points to the west, and, guessing that this change would have its effect upon the weather, Jack and I started at once again, leaving Sam Dewey to his duties in camp.

By the time we had crossed a little river and come out upon a wide marsh we could hear Dewey's axe-strokes from among the birches, and as we walked over a rise we found to our disgust that two stags, which must have been lying down upon the marsh, had heard them also, for we saw the pair trotting away over a ridge, and soon afterwards we came upon their fresh tracks. We only saw them as they passed over the sky-line, therefore we neither of us got more than a momentary glimpse of the stags, which, however, was enough to tell us that one was a very fine animal. His track also was large. A caribou differs from either elk or moose in that, when once he is frightened, it is almost hopeless to expect to see him afterwards. A moose 
will often travel ten miles, yet, if you are determined to do so, you can generally come to terms with him again. But a caribou in a similar case will altogether abandon the part of the country in which he has been jumped. Thus we were aware that if the two animals ahead had winded us or our tracks to follow them would have been worse than useless. But as matters stood I did not believe that they had been much frightened; consequently, as one of them appeared to be a particularly big fellow, we pushed on upon their trail not without hopes.

For the first couple of miles the big slots were very plain, but after this the nature of the ground changed and hard, bald barrens took the place of the marshes. From each of these we spied the country ahead, but for two hours we saw nothing of the caribou, and I was thinking of giving them up, as we could not tell in which direction they had gone, when we suddenly perceived them sparring together upon a sloping barren about a mile distant. I took out the telescope, only to find that the damp had clouded the lenses and that without a thorough cleaning it was practically useless. Fortunately, however, the stags were in full view, the wind was absolutely in our favour, and the country broken up by boulders, which afforded good cover. In these circumstances we were able to go forward at a good pace, but, to our vexation, long before we came within range we saw the smaller of the two stags walk away over the hill, followed immediately by his companion.

We lost little time in reaching the hummock over which they had vanished, and, crawling cautiously round the base of it, we found ourselves quite close to the smaller stag, which stood with its head up looking out over the country like a sentinel. For a moment we failed to sight the big stag, but soon we perceived him feeding just over the top of the next rise. Half of the great yellow body was visible, but his head was down, and in that position two or three 
steps took him completely out of view. We were expecting No. 2 to follow him, when, to my mortification, he quietly lay down. To go further was impossible without alarming him, so we also lay down and passed the time in cleaning the telescope. When it was ready we had a good look at the sentinel stag, and I was delighted to find that he carried a very tolerable pair of horns and was in all ways a mature stag. Beside his comrade he had looked "nothing at all," as Wells put it.

My only fear now was that the giant would travel away while we were forced to wait; still the chances were in favour of the stags remaining together, and as the one that was close to us showed no sign of uneasiness I concluded that the other had lain down on the further side of the ridge at no great distance. We remained where we were as patiently as we could for the better part of two hours before the inconvenient smaller caribou at last rose and, stretching himself like a dog, walked off at right angles in an aimless kind of way. By this time our coats, which had been very wet, were frozen quite hard, so that they crackled with our first movements. Before very long we were peering over the ridge where the big yellow stag had disappeared. My supposition had been correct, for I soon made him out lying down about two hundred yards away on the opposite slope directly in front of us. A glance at the horn nearest to us was enough to settle all doubts; a more massive antler no hunter could desire. Then with the telescope I tried to discover its fellow, but in vain, for the stag carried only one antler. Without a word I handed the glass to Wells. "That's the stag we saw last year, don't you think so?" he said at once. In fact there was no room for a doubt, for, besides its extraordinary weight, the horn was of a peculiar shape - a long, sharp spike protruded some eighteen inches from the beam between the brow and the bay.

It seemed probable that this stag had never possessed 
two antlers. On the other hand, it was just possible that he had in two consecutive years knocked off the second horn fighting or in running through the woods when it was in velvet. We could talk with perfect safety in the wind that was whistling off the frozen barrens. The ground between us and the stag was ideal for stalking-covered with boulders and hummocks of moss. The spot was obviously a favourite feeding place of caribou, for the cream-coloured reindeer moss was cropped as close as if it had been cut with a lawnmower. By using a little care we were able to get within sixty yards of the big stag, and we waited watching him. Presently he faced us, and neither with the naked eye nor with the telescope could I make out any sign of the missing horn. Unquestionably he was one-horned.

After a while he got on his feet and began feeding straight towards us, until at last I could see the colour of his eyes and even, as I fancied, the ruminative expression in them. At length he stopped feeding and raised his head. We were directly below him and only some fifteen or twenty paces away. He must, I imagine, have seen his companion upon some neighbouring barren. This was the moment to shoot, for in another he would pass over the brow of the rise, but instead, finally making up my mind not to shoot, I took up a small pebble and tossed it at him. It did not hit him, but in that second he became another creature. His head went up into the inimitable stately pose of a startled deer. He stood thus for a moment, then the great one-horned stag galloped ponderously over the hill.

In the following year he had a third escape, for it happened that the veteran Bob Saunders was guiding a sportsman over the same country when they fell in with and stalked an enormous one-horned stag. Saunders wanted his sportsman to shoot it, as he suggested that it had only recently dropped the second horn and, by following the animal's tracks backwards, they might find it. The sports- 
man, however, did not see the matter in the same light, and so the one-horned stag was once again spared. From Saunders' description of its single antler I have little doubt that it was the same animal which I saw in 1903 and I904.

This incident is interesting from one point of view, as it goes some way towards proving that the caribou migrates in more or less the same direction every year and returns again and again to the same autumn haunts. A further proof is afforded by the fact that the track of an immense caribou has been seen intermittently for several seasons near, I believe, Lake Mollygojack, or at any rate in that district of the island. These tracks are so remarkable that they have been photographed.

The size of a track does not, however, bear any relation to the size of the antlers of the stag that makes it, a fact brought prominently and disagreeably to my notice on the next day when, early in the morning, we struck the tracks of a band of some eight or ten caribou, amongst them a stag which gave us a splendid day. We found the trail quite fresh in the snow, and in due time saw the stag himself lying down among some boulders. A number of does kept such good watch, however, that it was late in the afternoon before I got within range, when I shot the stag through the neck. The head was a very disappointing one of twentyfive points, although the animal himself was perhaps the heaviest I have ever seen.

The weather was now turning bitterly cold, but at last the wearisome rain had ceased and been succeeded by a hard frost which continued day and night. On the morning of the Ioth I fired a long shot at a stag as he galloped along a ridge, and missed him just as he disappeared into a belt of pine. Running round this, I was in time to see him emerge not more than fifty yards away, but then I saw that his head was much lighter than I had thought, so I did not kill him, which I could easily have done. During the re- 
mainder of the day we saw two or three stags that had dropped their horns, and it was very obvious that the season was practically at an end, and I therefore decided to rejoin Wynyard after one more day's hunting.

As that was to be our last day except on the eastward trail we started at daylight. It had been snowing in the night and from time to time there were other slight falls, driven up by a bitter wind. It was already past eleven o'clock when, in a valley at the southern end of Island Pond, we spied three stags and several does. I do not know if these deer had been fired upon by the Gambo shooters, for, although they did not move much, they kept an exceedingly good look-out, and, though presently the two biggest stags lay down, they chose a quite inaccessible position in the centre of a marsh, from which they did not rise till past three o'clock. Had it not been so cold I should have enjoyed the long wait, as the deer were throughout in full view, one of the stags assuming a position I have never seen a caribou take before or since. He lay down on his side, with one horn resting on the snow and the other sticking up to the sky. Finally, when they moved off over the hill, we were glad to take a little exercise to restore our circulations under cover of the ridge before following their tracks in the snow. As these led into a belt of trees we soon came up within sixty yards, and one of the big stags-I could not tell which of them, as his head was down-was feeding on the far side of the herd almost opposite to me, and I was just about to fire when Jack whispered, "That is not the big fellow." At the same moment a doe saw us, and the next the whole band were in a wild stampede, led by the stag at which I had been aiming and which I now recognised as the one that had lain down in so curious a position. I fired at him and heard the bullet tell, and then, as I was trying to eject the cartridge, the other big stag broke cover almost in front of me. He was so close that, had he not swerved, he 
might have knocked me over. Meantime I was still struggling with the refractory cartridge, and when at last I succeeded in getting it out and another in the stag was going away end-on at about fifty yards, when I fired at the back of his neck and missed. After galloping another hundred and fifty yards he stood and gave me a chance of a beautiful broadside shot, which passed over his back, and he went off unhurt.

I was naturally chagrined and furious with myself for missing such an easy opportunity and still more for my idiotic performance in allowing myself to change from one stag to the other at the last moment, even though I had not seen the second stag until he broke out almost on top of me, for a bush had screened him entirely. Yet all the time, Wells told me, this animal had really been nearer to me than any of the others. We followed him in rather an unhopeful frame of mind for about half an hour and then returned to look for the first I had fired at. We found him lying by the edge of a little pond. His head was a very fairly good one, though, I think, a little inferior to that of his companion.

Early next day I climbed a hill to look for the smoke of Wynyard's camp fire, as I imagined it more than likely that by this time he would have moved from the spot at which I had parted from him. This turned out to be the case, for I quickly perceived the smoke rising some ten miles away to the north-east. As far as I could judge he was camped in the woods by Foxy Lead. I determined to rejoin him, hunting on my way, as by striking to the south-east I could still pass through some country that we had not visited. Late in the afternoon, just as we were on the point of turning back, Jack Wells spied a large stag that was feeding, escorted by fifteen does. Still sore from my experience of the previous day, I stalked him carefully to within a distance of something under a hundred yards, when I shot him 
through the lungs. Afterwards we took his head and that of the stag I had killed on the previous day into Wynyard's camp, where I was delighted to find that my friend had added another nice head to his bag.

We cached the canoes on the following day and were able to travel very light, and consequently made the longest journey I have ever done at a stretch in Newfoundland. Starting before dawn with our packs we reached our base camp at Butt's Brook the same evening and, pushing on at once in the flats, arrived at Terra Nova station by eleven o'clock at night. On the way out, just before we reached Sir William Whiteway's Drogue, we came upon the fairly fresh tracks of a bear.

On the whole the Igo 4 trip was disappointing both as regards the number of deer seen and as regards the size of the antlers, for whereas in I903 I alone saw a hundred and twenty-one absolutely shootable stags, in I904 Wynyard and I only saw seventy between us, and of these a large proportion carried very poorly-grown horns. As to the number of the deer, it is certain that we failed to strike the main migration, which did not pass through the Terra Nova country in I904. The caribou are admittedly arbitrary in their movements and change their course every year; the diminished horn growth might be attributable, as I have said before, to the severity of the spring of that year, the prolongation of the cold seeming to hold back the normal production of the antlers of the caribou in Newfoundland. I believe that in that year, I904, no head of over thirty-five points was brought in to St. John's.

Apart from this universal poverty of horn growth, the wetness of the season added no small item to our disappointment, for we missed the usual lovely October weather, to which I had not only looked forward myself, but had led Wynyard to look forward also. For all that I believe we both enjoyed our four weeks on the barrens. 


\section{CHAPTER VI.}

AN ELK-HUNTING SEASON IN NORWAY.

[Note.-The chapter following is included in this book as the author thinks it may interest his readers to compare the methods adopted in Norway in hunting the elk (Alces machlis) with those in vogue in America for hunting the moose (Alces americanus), the New World form of the same animal.]

T N I905 I decided to try a season in Norway, and in purIsuance of this plan I rented eighteen elk-rights in the province of Namdalen. Most of the elk forests in this district form part of the area of various farms, and consequently the rights belong to the farmers, and upon each "right" an elk, either bull or cow, may be killed.

The Norwegian farmers live a free, if hard, life, but they derive in many cases their chief means of comfort from the leasing of their sporting rights. The cost of a licence to shoot elk is roo kroners, a little more than $£ 5$, and the elkrights cost from $£ 5$ to $£ I 5$ apiece, according to the chances of success which they offer. A certain number of rights are to be hired in London, but as a rule better value is to be obtained by dealing direct with the farmers or owners. It has of late been the wise policy of the Norwegian Storthing to cut down the length of the shooting season; from two months it has already shrunk to twenty-one days, so brief a period as to force strong temptation upon the hunter to 
hunt " not wisely but too well," in the sense of hunting without rest or allowing himself any remission of effort. Should these three weeks ever be curtailed to two, it would, I imagine, be a mistaken policy, as not many British sportsmen will pay a licence and a heavy rent for a fortnight's shooting; indeed, individually he grumbles a little, and sometimes more than a little, even now, for it is safe to say that few tenants of elking-rights kill their limit, at any rate in northern Norway.

I arrived some three weeks before the elk season, which opens on the Ioth of September, and found my headquarters on a flat hill-top overlooking a long stretch of the Namsen River; there we dwelt in a Noah's Ark house, scaled to human size, which, with one or two similar arks, stood round an oblong of unkempt grass. I put in many pleasant days after ryper and blackgame, during which, if my bag was very small, I at least had good opportunity of learning the limits of my ground, as well as of occasionally taking an elk-hound, but no rifle, over the hills.

The farms, over six of which I had acquired rights, were one very like another, containing, save in the lower valley of the Namsen and a few acres round the saeters, very little cleared ground, the remainder of the land being made up of marsh, mountain, and forest. During the summer the cattle are herded on the hills which form the elk-grounds, but very shortly before the elk season the saeters are abandoned and the rights left to peace and quiet. The sudden appearance of a Lapp encampment upon one's most promising ground is always a possibility, and one which entirely destroys all hope of sport in its not only close but very wide vicinity. Of recent years elk have increased largely in numbers in Namdalen, although, owing to the ruthless way in which the young bulls are shot, good heads are not common.

On my six farms were four saeters, or huts, from which 
the outlying districts could be conveniently hunted. Before the season opened I visited these saeters, and was able to gain some knowledge of the ground. At the last moment I rented an extra right which the owner, a farmer in a small way, declared to be excellent, and as he was willing that I should walk over the ground with an elk-dog I did so. This right, on a farm called Brusvasaasen, adjoined my best Elstad ground, and among the raspberry canes, which covered the hillside, there were such evident traces of elk as to convince me that the farmer was in the right. I therefore came to an arrangement with him.

Elk-hunting in Norway, though it demands hard work and effort, compares unfavourably in my opinion with moose-hunting in that it must be pursued on long-occupied ground, and does not give anything like the same opportunities for wilderness life, but is in fact carried out under conditions rather similar to those of an exceedingly rough Scottish shooting. Although I took a tent over, I could never succeed in persuading the Norwegians to use it. They objected on the score that to camp in a tent would only result in driving away the elk, who took little notice of the summer camps in the saeters because they were accustomed to them, whereas the unfamiliar sight of a tent camp would alarm them. As I had always, out of England, hunted in countries where the whole land was free, I felt at first a good deal irked by the boundaries, and indeed during the whole season never quite attained the sense of freedom, which is the main charm of a hunter's life.

Apart from this, however, Norwegian shooting does possess one or two great advantages, the chief of them being that no part of any animal killed is wasted; and although I consider it absolutely legitimate to shoot an animal for his horns, yet it is certainly much more satisfactory to know that the flesh is valuable as food. The sportsman's share of any animal he kills is the head and 
horns with the hide and about 50 lbs. of elk-beef; the remainder of the carcase goes to the owner of the farm on which the elk is first shot at, whether actually killed upon it or over the boundary upon the land of his neighbour. But if a hunter kills outside of his rented right he must always be able to prove ownership by the tracks, which in the soft ground and moss generally leave a clear record.

When I leased my rights in the spring Kristian was already engaged, but he procured for me another hunter, Peder Rodseth, who was said to possess an excellent dog. In hunting elk success depends to an enormous extent on the hound, and Peder's Bismarck, though not to be compared with Kristian's dog of the same name, could hold his own with most others. One windy night Peder came to be introduced, and we held a conversation limited by the fact that he knew about half a dozen words of English and I as many of Norwegian. But for all that Peder proved a capital companion, for whom no day was too long, and his persistent cheery optimism was a delightful quality during the long period of ill-success through which we passed together.

The diverse methods of elk-hunting adopted in Norway and Sweden have been described by many writers, and very few words need be said of them here. In both countries the hound is used, but whereas in Sweden it is loosed on the trail of the elk, in Norway the dog is yoked with a breast harness to which a leader some seven or eight feet long is attached. Held in leash in this manner the bind-hund, as he is called, does the work of leading the hunter to his quarry.

The end of August and the opening of September slipped by, but as the great day, the Ioth, approached a new order of things was ushered in. Tall bearded men in Lapp boots, and each accompanied by the inevitable elk-hound, stalked down from lonely dwellings in the hills to the skyds-station 
where we lived; they sat about on the steps of the post office opposite and discussed the events of local historya saeter girl had seen a bull elk of eighteen points, a lynx had killed two sheep across the river, that the old hound grew more cunning with the passing years. Once or twice spasms of political forecast, for war seemed imminent, shook the little group, but always in the end the orbit of talk settled round the magic word " elg."

On the eve of the Ioth Peder reappeared, shy, dignified, with a neatly-trimmed beard and his hunter's suit of homespun supplemented by a new cap with ear-flaps. His first words after our handshake were "Very elg Gartland," which I understood to mean that a number of elk were to be found in the Gartland Woods. Then, after a prolonged pause, he added, "Big bool imorgen," plainly a prophecy of good luck in the morning, made the more clear when, by way of illustration, he placed his hands on either side of his head in turn with eight fingers outstretched, cheerfully indicative of a sixteen point bull.

I was up early to find a misty morning with a promise of rain, that continued to threaten all day but did not fall. The weather to hope for, the weather proper to elk-hunting, and that most conducive to success, is a gale of wind with torrential rain beating down through the tree tops, for the noise of the storm, as well as the soft condition produced under foot, tends to cover the hunter's approach from the large keen ears of his quarry. In those thick forests the walking is almost invariably bad; moss, wind-fallen trees, often boulders and slippery surfaces of rock, and, worse than all, dry branches and decaying brush make silent progress a matter of extreme difficulty. My lot during the best part of three weeks was bright weather with a hot sun, and towards the end frosty nights with crisp grass and frozen pools.

Though I was up before dawn, Peder was waiting for: 
me with a cariole, as I had decided to start by hunting the Gartland Forest where the big bull had been seen by the saeter girl. After putting up the horse at Gartland Farm, we commenced a laborious climb to reach high ground, for although later in the year elk were found in the lower pine forests, at the time I write of boys were herding cattle in them, and they were consequently useless. This long preliminary climb to reach the elk-grounds, when undertaken daily, makes a very definite addition to the call upon the physical energy that is needed for the direct purpose of hunting. In dull, quiet weather we ascended, but we were met on the ridges by a strong wind, which whistled through the spreading thickets of dwarf-birch and ruffled the surface of the upland waters. Under foot mosses made a carpet of pile a foot deep and of colours beyond imagination, reindeer moss threw its lace of yellow and white over hills and hollows, and the ground was everywhere starred with golden multebære. It is on such ground as this that the Norwegian elk passes the hotter part of summer,' until stress of weather drives him to take shelter lower down among the trees. Yet even in September, when the sun shines out after a night of storm or of frost, he is apt to climb away from the fringes of the forests and to spend the day on the higher levels lying in some marshy hollow.

On that first day we patrolled the sombre woodlands and the breezy open, but not a sign of elk did we see, and the evening closed upon the non-fulfilment of Peder's forecast. This went on for four days, during which Bismarck stalked ahead in his leash, for the most part with listless indifference, only once raising our hopes by a more alert demeanour, which, however, ended in nothing more exciting than a glimpse of a spike-bull already skrcemt upon a distant hillside.

Half the charm of elk-hunting centres on the dog, without whose aid, except on the very high and open field where 
spying with glasses is possible, few trophies would be obtained, and many farmsteads would lack their winter supply of salted meat. The ordinary elk-hound is nearly allied to the husky, though, unlike his congener, he displays towards human beings a kindly nature. Between themselves the elk-hounds are very pugnacious, and when an elk is killed the tracking dog is generally unwilling to allow any one, save his master, to approach it. There seem to be two distinct kinds of elk-hound, one smaller than the other, but it will be as well to drop generalities in favour of Bismarck, whose companionship gave me an immense amount of pleasure, and who was responsible for such success as I obtained. Early in our acquaintance a suspicion arose that the dog, who, as I was proudly told by Peder, was accountable for the death of sixteen elk, acted in months other than September the part of bird hound-that is to say, he was accustomed to bay beneath trees on which capercailzie or hjerpe were perched, until his master arrived with a gun and shot them. But for all that he was a useful dog with a fine nose. One of the interesting points about Bismarck showed itself gradually as the season advanced. A marked alteration took place in his character-day by day he went back more and more to the mood of savage nature. At the outset an affectionate animal, with a wagging tail and a keen eye to the main chance, by the end of the three weeks he would growl even at his master, and he ended the season by attacking a farmer upon whose ground we killed an elk. Undoubtedly the original strain was strong, and perhaps not so very many generations have elapsed since the ancestors of Bismarck chased the elk in wolf-packs as the wolves do to-day during winter snows, though in the summer time they withdraw to the higher ground of the mountains towards Sweden.

It is strange that the wolf, above all his brothers of the wild, remains the chosen hero of legend and romance from 
the nursery tale of Red Riding Hood up to the present. His very name calls up a vision of the North, and even those who know the slinking, nor always mangeless, creature of fact are conscious of the touch of glamour that hangs about his name.

But though at that season no wolf was likely to be visible, there was always a shadowy chance of seeing a bear. How one longs to have the luck of

“. . . Boys who unaware,

Ranging the woods to start a hare, Come to the mouth of the dark lair Where, growling low, a fierce old bear Lies amidst bones and blood."

However, the hunter in Norway generally lives on the belief that on some incredibly lucky day he may meet with a brown bear and so add to his record, if fate permitted, the last (if we except the aurochs, the right of shooting which is vested in the Czar and one or two of his nobles, and which can therefore scarcely be included in the general list), the very last, of the dangerous big game of Europe. In using the term dangerous big game, I refer to each species taken collectively, for, although not ordinarily dangerous, the elk is said to attack on occasions, especially in the rutting season. Nearly every Norwegian hunter has a story to tell of an elk that with its powerful fore hoofs has torn open a man's body. A few of these tales may be true, but it is certainly also true that a man may follow elk for fifty seasons without coming upon that traditional slem elg.

On the I4th of September, late in the afternoon, we had turned homewards through the forest, having failed to find sign of elk, when suddenly without warning four great grey shapes sprang up from among bushes and bracken upon our left. Peder sent me an excited whisper, "Bool! Bool !" I ran forward and made out the horns of the bull, 
and got in a shot as he plunged through the underbrush a mere glimpse of black shadow. At the shot the bull turned a complete somersault, clean head over heels like a gigantic rabbit, and lay still upon the further side of a little patch of trees. I ran round to get a clearer view, or rather a view at all, for the elk was now entirely hidden. But no sooner did I catch sight of him than with a grunt and a crashing of sticks he pulled himself to his feet and began to make off through the dense wood.

Meantime my rifle had jammed with some pine-needles which had clogged the action, but just as the cartridge was released the bull turned and crossed my front some hundred and twenty yards away, giving me a fair chance. Owing to the excitement of the moment, as well as the fear that the elk would vanish into the thick timber, I shot too quickly and without making due allowance for the nature of the ground, which fell away at a sharp angle; thus, to the best of my belief, the bullet passed over the elk without touching him. Still I thought it possible that the elk would not go far, and we followed his trail and discovered some blood spoor. Bismarck was beside himself with excitement, straining at his harness and yelping. After a while we reached some harder ground and lost five minutes, for Bismarck took us off on the trail of one of the startled cows.

From this we came back and picked up the bull's trail again. It led away downhill, then the elk had turned at a sharp angle, and begun to ascend the mountain side once more. Meanwhile the rain was slashing down upon us from the sky and pouring in streams from the trees. It was clear from the trail that as he neared the top of the hill the elk had slowed down, unable to keep up the fierce pace of the start. So, too, alas! had we. Running up a Norsk mountain-side through forest at top speed is a feat beyond even the natives of the valley, and very far beyond 
-in my case-the power of the alien sportsman. But I followed as fast as was possible to me. So complete and so sudden had been the downfall of the elk to the first shot that I had fancied that he would not travel very far, so instead of hurrying along in his tracks I took things quietly and went at my leisure. But ill-luck was with us, for by some misfortune the hound slipped his leash, and with an echoing bark at every spring he bounded away in pursuit. After this there was no time to be lost, though soon the barking ceased; but we hastened forward, and, coming over a second rise, heard Bismarck again, but from the sound he appeared to be stationary and was probably baying the elk. By this time it was raining so hard as to make tracking very difficult, and shortly when the barking began again to fade away into the distance, I realised that my chances of seeing the elk again that day were slender ; and, indeed, I did not see him either then or after, though Peder and I searched the woods for him during the following days. As to the bull, in thinking it over it seems likely that the first bullet touched his backbone and creased him, and at the moment of writing he is probably wandering in the forest, none the worse as far as I am concerned.

After this, for many days-to be exact, twelve days and their twin nights-we had nothing more encouraging to vary our thoughts than regrets for the lost bull, though on one occasion while walking down a forest glade we saw the long, Roman-nosed face of a cow-elk regarding us steadfastly from a little distance. Of course there was no shooting, and the woods soon swallowed her up. Several times in the course of those twelve days we knew ourselves to be close to elk, but always in thick timber, so that sometimes we could hear the great creatures feeding and moving, but not once did we gain the slightest glimpse of them. These were generally still bright days with wandering winds, such as are in their season very pleasant to all the world 
but to fishermen and hunters, two deserving classes of the community often much maltreated by the weather.

Elk-hunting was for the time a game of hide and seek, played out in the vast labyrinth of the woods. On several occasions a very slight softening of the iron countenance of fate would have given us all we needed, but the ill-luck held remorselessly until even Peder spoke no more of "vera bool," although he marched on untiringly over endless kilometres of wood and hill. We wore out our Norwegian boots in our long-day tramps, and existed on hope, fladbröd, trout, and an occasional bottle of beer, and-the irony of it-the meat of a bull-elk, one of two which had been shot by Geoffrey Gathorne-Hardy in a beautiful right and left higher up the valley!

Poor Peder! darkness clouded his spirit, but only for short intervals. Evening by evening he would say, "Bismarck kill big bool imorgen," but neither the next morning nor many subsequent mornings brought us in sight of a male elk. The only event worth mentioning during this interval might have ended disastrously. We were hunting on Gartland, and about nine o'clock in the morning were crossing an area of unusually dense forest. Bismarck had been trotting along listlessly, so that we were therefore all the more delighted when he suddenly stopped short and then commenced to pull hard up-wind. From the way in which he carried his head Peder at once said "Elg," and intimated by signs that the dog had the scent straight from the animal's body. A good Norwegian hunter can read a great deal from the demeanour of his dog, and can always approximately tell the distance, small or great, from the quarry. I myself learned to do this to some extent with Bismarck, for when close to an elk the hair along his back stood straight up and his tail curled more and more aggressively over his back.

In the present instance every sign proclaimed the near- 
ness of the elk, and we passed into a pine-wood, treading most carefully. Five minutes' walk through this wood brought us to a little clearing, across which we went quickly and into the shadows on the farther side. We were now in a tongue of woodland that extended out upon the hillside. My attention was fixed upon the hound; his hair continued stiffly erect, and I made up my mind that the elk was on the other side of a very thick clump just ahead, and, signing to Peder to keep back, I cautiously advanced.

I was soon aware of something brown on the far side of the bush, and very gently put another foot forward. Probably I have never been in greater danger than at that moment, for I saw suddenly that this was no elk towards which the hound had led me, but another hunter, who was as intent on my progress as I on his stillness. $\mathrm{He}$, as a matter of fact, was in no danger, for he was standing in the open; moreover, I would never shoot without looking at and getting a fairly good idea of a bull's horns. But the Norwegian was out for meat, and meat alone; he would have preferred a cow to a bull, and the native hunter is very apt to fire at anything that moves in a bush. The man turned out to be a hunter employed by the farmer who owned the rights upon the adjoining land, which chanced to be unlet that season. He had been sent out to shoot meat for the winter provender, and had wandered over the boundary into Gartland. Why the dog led us to him I cannot explain. Peder assured me he had never done anything of the kind before, and certainly afterwards, while hunting with me, he never made that kind of mistake again.

On the 26th of September, with only five days of the season remaining, we set out for the largest of my rights, the chief drawback to which lay in the obligatory three hours' climb before the good elk-ground could be reached. There was, however, a convenient saeter to which we journeyed with some of the feelings of a forlorn hope. We 
started in company with Geoffrey Gathorne-Hardy, he of the right and left, who had come down the valley the previous evening, bringing with him news of a fine bull killed by his brother.

The sun was high when we came in sight of the saeter, a solid log hut roofed over with turf on which grew long grass and flowers that waved in the wind.

After visiting it we climbed over the hill and came out up on the fjeld beyond it; here Bismarck took a "luft" and led us to the fresh tracks of a cow and a calf, which we saw again later among the trees of a neighbouring right. The dog was pulled off the trail and taken, close hauled, in another direction. We next entered a grove of young birches, which drew blank, but emerging from it Bismarck began to show interest and to sniff the wind that was blowing down the farther cliff. It was most curious to watch him from the instant he lost his indifference. As owing to the unsteady breeze it was impossible to locate the elk immediately, we sat down to give Bismarck time to investigate and to think it out. He settled very quietly on his haunches, the thick white and grey hair on his neck bristling a little, and the muscles of his nose twitching and working. At first the airs were light, but presently followed a stronger gust, at which Bismarck rose and began to lead away resolutely nearly up-wind, under a sky already darkening for storm.

Peder, of course, whispered great expectations in his broken words, and sincerely I hoped that this time they would be justified by events, though to tell the truth I was doubtful, for the hound's nose was so extraordinarily fine that he had often led us a mile to an elk-trail, and I feared that in the present instance history might once again repeat itself. However, I was happily disappointed, for at the end of half an hour I caught a glimpse of the hindquarters of an elk, the rest of the body being screened from 
sight by some trees. It was impossible to tell whether it was a bull or no, but while we crept round in hopes of getting a view of the head Bismarck broke into a whine, and the long-sought elk was skramt and making off at full speed through the wood. Peder suppressed Bismarck in a definite though momentary manner with the lunch-bag just as I commenced running to cut off the elk. Some halfway up the hillside I sighted the animals, two of thema bull and a cow. The cow dashed on, but before the bull could follow her I took as steady an aim as I was capable of after my run and thought I heard the bullet strike. On the shot, as do all but the best elk-hounds, Bismarck broke into a series of excited yaps.

By this time the bull had dashed in among some pine trees, but the cow had run in a circle and now reappeared; she looked at us for a moment and then also decamped up the hill, where in the shadow of the trees I obtained another shot at the bull as he melted away into the dusk of the forest. This shot was fired at a great distance, and I had no reason to think it took effect. On coming up to his tracks, however, we found signs that he had been badly struck, and after following the trail for some little time I directed Peder to sit down for a rest and light his pipe. He was very jubilant and very sure we should get the bull.

In the course of half an hour we started again, took up the track, and, save for one check by a small river, through which the elk had waded, made good progress, though it was sometimes necessary to move with extreme caution, for the signs all the time showed us to be quite close to the wounded animal.

The elk led us in a complete circle, and for a long distance, so that when dusk was falling we had returned to the hillside upon which the first shot was fired, and at the foot of which lay a lake of some size. Into this the elk had waded; we could see his huge footmarks showing through 
the still, clear water upon which the evening glow still shone.

The elk had waded out deep into the lake and then begun to swim, so we lost no time in making our way to the nearest point on the opposite shore where he would be likely to land, and commenced to search for his trail. But, although we searched long, we came upon no indication of his having come ashore. Even with Bismarck's help we failed to discover any trace of him, and long after dark we returned, worn out and bitterly disappointed, to the saeter.

Once we gained this haven of rest the fire was quickly lit in the big iron stove, its light shining out upon the darkness until we closed the door and prepared to take our meal in a despondent silence. It is strange how persistently the sting of a lost opportunity frets the heart of a hunter; a successful or difficult shot has not the power to elate him in any corresponding degree. He is apt, and rightly apt, to give the credit to the modern weapon of precision. But let him miss a shot, a fair shot, or, far worse, lose a beast after wounding it, then it is well to draw a veil over his next hours. So it was with me while I watched the firelight gleaming on the rude walls and endeavoured to account for the disappearance of the elk, an effort in which Peder's comment gave me no aid, as he repeatedly pronounced the lost bull " an evil beast." I concluded finally that either the animal's strength had failed in the middle of his long swim across the lake, which was possible, though to my mind exceedingly improbable, or that after entering the water he had turned back northwards and regained the shelter of the woods from which he originally emerged.

Presently Bismarck began to growl, and almost immediately a bearded face was pressed against the window pane, then the door opened to admit its owner. Peder 
introduced him in form "Dis mann haf elg ve schutt dag," which seemed to indicate that our visitor was the farmer on whose rights I had fired at the elk, and that had I killed it he would have become the pleased possessor of the resulting meat. Acutely conscious that in the eyes of Mathias my shot should have procured a winter's supply of food for his household, I felt there was nothing for me to say for myself. But Peder was clearly far from holding the same opinion, for he broke out into a rising tide of Norsk narrative. Meantime Mathias had been supplied with hot tea, and to its comforting effects I attributed the almost seraphic smile which, as he listened, slowly overspread his weather-wilted features. Then he in his turn began to speak, while Peder translated after his own fashion, and I learned the signification of that breadth of smile. I gathered that Mathias prophesied smooth things; it appeared that he had a boat upon the lake into which the elk had plunged, and he predicted that we should get the animal, and that he and his should yet eat the meat thereof. At length he took his departure, it having been arranged that he and his boat should be at my disposal a little before dawn.

The hour found us at the rendezvous. We stood high on the side of a hill and watched the mists coiling in the valleys below us. At first the summits which rose all round showed like giants wading shoulder high in a foggy sea, but as the sun mounted higher into the sky the mists began to uncurl and heave and finally to drain away into the warmth of the upper air. We descended quickly to the lake-side, and the woods sweet with dew and dawn seemed still and listening as we pushed out upon the bosom of the water. In the boat I found a cast antler of great size and beauty, over which I sighed, and which I suspect Mathias had placed there as a spur to my enthusiasm. Tyr knows it needed none! Before long we arrived at the spot where the elk had taken to the water; there we landed 
and began our search in a new direction. We had not gone far when Bismarck suddenly bounded forward on his leash. Mathias crowed in his delight, and in another instant Peder and I were hastening through the trees on the rediscovered trail. Evidently the elk had entered the lake, and had either found himself too weak to cross it or, as I think, simply meant to throw us off his track, and had for a time succeeded only too well in doing so. Bismarck now raced along the trail at a great pace. At length we jumped the elk among some pine trees three hundred yards ahead, and then for another steady two hours we followed him. At the end of that time I had almost given up hope that he would ever stop ; as we passed through a young wood we were aware of the huge, high-shouldered beast standing in the middle of a marsh with his back to us. Peder urged me to shoot at once, but the animal was in a bad position, and I was determined to take no more chances. He was quite unaware of our presence, and I waited a little, hoping he might turn broadside on. But he did not move, and I began to be afraid of his starting off again. I aimed carefully and fired. He was about one hundred and eighty yards from me, and at the shot he turned, giving me as he did so the first clear sight of an elk's shoulder I had yet had in Norway. I immediately fired again, and on receiving this last bullet he collapsed. Immediately Peder ran up and Bismarck leaped upon the body, tearing out tufts of its hair, rolling on it and barking. I found that two of my shots had missed the bull. When we came to examine the head we found, as I had expected, that it was a poor one, although-and this is very frequently the case-the body of the elk was both large and heavy. After using the knife Peder and I retraced our steps to the lake, and I waited on the nearer side while my hunter and his dog went off to fetch Mathias, who presently appeared with his entire family, including a toddler of about four years, all vocifer- 
ous and happy. Two other farmers, part-owners I suspect, also turned up. Mathias took a long look at the bull, assured himself that it was very fat, then crossed over to me and solemnly shook hands, a ceremony which is the equivalent of the Norwegian "thank you." $\mathrm{He}$ and the whole party were in high spirits, for the elk was in size and condition a most satisfactory perquisite. There is rather a shrill-voiced humanitarianism which condemns the killing of wild game. I think if these good people could but see the joy of the Norsk farmers when an elk is killed on their ground they might incline to a fairer judgment of the hunter and his craft.

After giving final instructions to Mathias concerning the head and horns, Peder and I resumed our quest, and I shall always, look upon the later events of that afternoon as among the luckiest of my hunting experiences. About eleven we lunched upon the hillside, and afterwards commenced a long and quite fruitless search for elk. For five hours we walked steadily, visiting many likely haunts, and during the whole time never came upon a single track or sign.

It was already four o'clock when we found ourselves upon another part of the same hill on which we had started the bull the day before. The slope was even more than usually precipitous and covered with a dense growth of birch. As we had so far seen no track and the dog had given no warning, I was just about to give the word for home (some dozen or more switchback miles away) when Bismarck bristled and began to lead forward in a manner suggestive of possibilities.

The wind had now changed and was blowing up the hillside behind us, so we took a wide cast to cover our advance, lest the elk, which we were now pretty sure was not far off, should, as is the frequent habit of these animals, have lain down to windward of his own trail. It was 
most fortunate that we did take this precaution, for in a very few minutes Peder turned upon me a face literally white with excitement. "Bi-i-g bo-o-ol," he whispered with a drawl of prodigious meaning on both words. I peered over his shoulder, and there, sure enough, at a distance of not more than two hundred yards below us, I at last saw the heavy dark head, bulged nose, and large palmated antlers of a truly big bull. The rest of his body was hidden by the thick green of a bush, as were also, I discovered later, a cow and two calves, the companions of the bull.

While Peder remained behind with Bismarck I cautiously stalked the elk, my heart thumping against my ribs, for one may go many seasons to Norway and not meet with such horns as it seemed to me this bull carried. The wind was exactly right, my way lay across moss, and altogether it appeared that fortune, who seldom does things by halves, was indeed in a generous mood. About a hundred and twenty yards away I settled for my shot, and just before I took it, looking back I was aware of Peder's face, paler than ever, peeping above a rock; his hands I did not see, but well I knew how they were occupied and that Bismarck would not give tongue till the critical moment was over.

I paused a moment to steady myself before drawing the trigger, and could see the transient gleams of sunshine upon the white birch trunks springing from their bed of green moss and the bronze and gold of wild raspberry leaves that shone in the duller background. All I could define to shoot at was the head and neck, and, not wishing to smash the skull, I chose the neck. At the shot the elk bounded to his feet and was lost to view. I heard a tremendous crashing in the forest and caught sight of the cow and the half-grown calves swinging along in full flight.

A moment's pause and then the bull blundered from shadow to shadow. He was struck in the neck, and not knowing where the shot came from he ran towards me, 
when a second bullet sent him rolling down the hillside. He was quite dead before even Peder could reach him. After eighteen blank days, to secure two bull elk in seven hours! And what a beauty this last head was! The elk stood 5 feet IO $\frac{1}{2}$ to II inches at the shoulder, and the horns showed thirteen points, with a broad and handsome palmation. As we stood above him both Peder and I agreed that the blank days were at last atoned for. But the first elk had cost us hours of unremitting pursuit, and we were wearily tired. I have wondered since how we should have managed that twelve long miles which lay between us and home if, having at length met with the " vera bool," I had failed in my shot and lost him.

On the following day Peder and I drove over to Gartland betimes, for since the luck appeared to have changed in our favour we were determined to force it. In fact so early did we arrive that it was not yet light when we turned our cariole into the yard of the farm, and even the early-rising Norsk farmer was not astir. Soon, however, we had unharnessed the horse and, having seen to his comforts, were making the best of our way into the woods. Gartland was, as I have already mentioned, the most closely-wooded portion of all my ground, and in ordinary seasons these pine forests undoubtedly hold elk, but during that particular year they were, owing to the extreme stillness of the weather, very difficult to hunt. The light frosts of the morning formed cat-ice in :every small hollow and cranny, and as the cattle had been recently on the hills their tracks were roofed in with white, so that in many places almost every step we took was a clear advertisement of our presence.

On this morning, however, the sun rose invisibly behind heavy rain-clouds, and soon the wind was threshing and moaning among the trees; I need not say how we welcomed this beautiful elk-hunting weather after the quiet 
sunniness of the last days. Having followed the river (where in spite of the turmoil of the rain I could see several good trout lying) for some distance, we struck upwards, and for a couple of hours hunted the precipitous side of the mountain without any success. At length we passed over the summit and emerged upon a kind of rocky terrace set high above a great forest of pines. After carefully examining what open ground there was without seeing anything, Peder rolled one or two large stones down the hillside in the hope of disturbing any animal that might happen to be lying close. This manœuvre proving quite barren of result, we descended once more to the foothills, and there at last Bismarck began to lead straight up-wind.

The ever-hopeful Peder at once whispered "Bool!" and then "Naer, naer!" which I took-I believe rightly - to mean near. I imagine Peder judged that Bismarck had the scent direct from the animal or animals, but that he was mistaken in this conclusion was quickly made plain, for in about five minutes or more we came upon the trail bending away to the westward across the wind. A hasty examination showed that there were three elk, papa, mamma, and baby, or, as Peder put it, "Vera bool, coo," and then signs signifying a little fellow.

How exciting were those whispered consultations with Peder in the pine forests, and, for the number of words used, very full of meat! And small wonder, since neither ever spoke without having something really necessary to say, and our limited knowledge of each other's national tongue forced us to compress our thoughts into two or three words at most.

Now at last the real glory of elk-hunting was ours. We could see from every movement of the hound that we were close, very close, to the quarry. At this crisis one of my boots-I was wearing red rubber soles with buckskin tops -commenced to creak, so I removed it and then crept 
on over the chilly ground until my foot lost all feeling. Within another few yards the wood began to thin, and as we came to the edge of it I saw the three elk. They were standing two hundred yards away in the middle of a marsh about a quarter of a mile in width. The bull was the nearest to us, but alas! he was by no means a "vera bool." I turned to Peder and shook my head. At this Peder began to be very troubled. " Schutt! Gartland farmer no elg!" he whispered reproachfully, which was quite true. For on the Gartland rights we had killed no elk, and there was the farmer's winter meat supply to be considered. Still it seemed a pity to kill the bull, for it was but a three-year-old, and in five or six years more might carry a good head. Who knows? But Peder had a second argument to back his advice. "Schutt bool!" and he pointed significantly at Bismarck. I knew all that he meant; the old Norwegian phrase, "Blood for the dog, meat for the man," expressed it, for in Norway it is supposed to be bad, and it undoubtedly is very bad, for a good elk-hound to lead to the quarry and be disappointed by no kill. For this reason many a Norwegian will spare nothing, bull or cow, tracked down by his dog.

I felt there was no more to be said, and as the elk had not moved much I settled myself against a tree and got the white sight behind his shoulder. At the shot he rushed for cover. It was difficult to shoot again, because the cow and her calf had run in between him and me, but I felt sure he would not go far. This turned out to be the case, for we found the bull, deserted by cow and calf, standing on the trail which led to the saeter. When he saw us he turned and trfed to go up on the hill, but he had no strength left, and another shot finished him. He proved to be a fine, heavy animal, and as such was appreciated by the Gartland farmer.

The day following was the last day of September, and 
therefore the final day of the season, so, accompanied as usual by Peder and Bismarck, I was off early. Until late in the afternoon, when Bismarck found a family of elk, a bull and two cows, in some very thick forest, the hours passed quite without incident.

But once the elk were found there ensued the usual long effort to get a shot in the thick timber. For nearly half an hour we were close to them, and it is possible that had there been any wind I might have obtained a chance, but in the intense stillness the victory fell to the great beasts, for, although at one time within fifty yards, I never caught a glimpse of them, and finally at the cracking of a twig they made off with all the honours of war, for their escape was chiefly due to the strategical position in thick cover that they had taken up.

We had followed their tracks until we found that the elk had crossed the Elstad boundary and sought sanctuary in the lower pine forest beyond. We used all that was left of the daylight in a barren search, at the end of which only five hours of darkness remained of the hunting season of I905, and there was nothing for us to do but to trudge home to the farm.

As I walked behind Peder along the forest paths I reviewed the closing season. On the eighteen elk-rights which I had leased I had actually seen four bulls and thirteen cows, as well as on three occasions a blur of moving iron-grey coat to which I could not assign a sex-all things considered, a not inspiring total ; and yet I am convinced that my rights were good and the comparative absence of elk was due to the peculiarity of the season, for the warm, fine weather had been continuous and had lasted much longer than usual. On this account the elk had lingered later than is their custom on the edge of the high fjeld, instead of, as in ordinary years, seeking the shelter of the pine forests. It was not until the last two days of the hunting 
season that I found any in the lower woodlands, that made up the greater proportion of my ground. Had the weather been stormy the elk would probably have descended to take refuge in the valleys at the least a week earlier than actually happened in that year. I have reason to believe that during the concluding five days there were six elk on Elstad where only one had been during the greater part of the season.

Personally I found the Norwegian mountains harder ground to hunt than any I had ever tried. One often hears of the forty and even fifty mile walks taken by elk-hunters, but I doubt if these distances, accurately measured with a chain, would work out at the same figures. As to running after a loose hound, as is done on the easier ground over the Swedish border, the man who could run over the Elstad or Gartland mountains I have yet to meet. For myself it was all I could do to walk over them day after day for many consecutive days.

As to the rank among field sports in which elk-hunting should be placed, it seems to me that for a hunter who worked his own dog the sport would be magnificent, and his chances of success-owing to the more silent approach possible to the single-handed stalker-would be more than doubled. For such sport, however, a very well-trained dog would be required, as before the hunter fired he must put his foot on the leash, and a $40 \mathrm{lb}$. or $60 \mathrm{lb}$. dog straining to release himself would not conduce to straight shooting. Of course once the elk was located it might be possible to leave the hound tied to a tree, but the Norwegian elkhounds that in such circumstances would not betray their presence vocally are few and far between.

The Norwegian system of training elk-hounds seems to be largely a matter of taking advantage of inherited instinct. Before the season opened the farmer Kristian Fiskum, the most famous shot and elk-hunter in Namdalen, wished to try a young dog about eighteen months old, which had never 
been out after elk, and for this purpose I accompanied him. We had walked for some hours, when the dog picked up the wind and led us to the fairly-fresh tracks of a cow and calf, and a little later brought us quite noiselessly within two hundred yards or so of the animals. Kristian was greatly pleased with this success, and on the strength of it took the dog out regularly. It was over this dog that later Geoffrey Gathorne-Hardy killed the right and left I have alluded to. Of course, as the hound is always on leash, and thus under control, there are but two qualities necessary for him to possess-a good nose and a silent tongue.

The most famous elk-hound of recent years in Namdalen was Kristian's Bismarck, which in I905 had to be carried all the long distances from place to place, but would still lead his master to elk. In the hands of a good trainer it is more than probable that an average elk-hound might be educated into an almost perfect ally in the chase of the great deer.

Although on the whole the Norway elk do not suffer greatly from out-of-season killing and year by year they are, I hope and believe, steadily increasing in numbers, yet but for the game laws they could and would certainly be exterminated. For towards the beginning of winter, upon the ground where we hunted, there arise occasional little groups of drab dwellings, which are presently overlaid by the allwhitening storms, and passing men on ski see flat Lapp faces, grimed with the smoke of upland fires, peering at them from behind the trees. To escape the rigours of the cold the Lapps desert their summer haunts on the high fjeld and drive their reindeer herds into the lower ground, and even in spite of the legal restrictions which exist it can hardly be doubted that the snow which periodically blots out much of the northern world covers also the traces of the Lapp poacher's shot as well-as the Lapshoe trail of the man whose finger touches the trigger. 
So the season ended for us', and on the following morning a small procession of carioles followed each other down the deep descent from the skyds station, we bade a regretful farewell to our Norwegian friends, and set out through the sombre forests on our way home. The gloom of the pines was now emblazoned with the autumn gold of the alders shivering in the cold wind; the soft greens of the mosses and ferns and tall rustling plants were touched by frost to fiercer colours-all was changed, the country no longer looked as we had seen it in August. There were five of us, accompanied by Kristian and his son, with sundry cariole boys. At a farm on the way we heard with some envy of a recentlykilled bear, but the only other incident of the long, cold drive occurred on the forest road within half a mile of the hotel on the beach of the Snaasenvand-a large capercailzie cock, disturbed by the passing of the foremost cariole, flew out of the trees, turned up the road, and skimmed so close above my head that I only missed him by a matter of inches when I struck at him with the whip-butt. After spending the night at the hotel, where we dined off seven different kinds of cheese, we found our way by motor-boat and cariole to the Trondjhem Fjord, and thence by steamer to the ancient capital of the Vikings, where at that period the population were wildly excited over the question of the separation from Sweden, which has since become an historical fact. 


\section{CHAPTER VII.}

MOOSE-HUNTING AND MOOSE-CALLING IN CANADA.

T N June, I906, I made plans to spend the following October in the Canadian woods and to attempt to secure that much-coveted trophy of American big game-a good moose. I was the more eager to hunt the greatest of deer, because, in the first place, I had long desired to shoot a moose, and, in the second, as I have narrated, I had passed the hunting season of the previous year in pursuit of his congener in Europe, and it certainly adds an immense attraction to any form of sport, if one has had experience of it under different conditions and in another environment.

On the IIth of October I landed at Quebec, and having been given permission by Mr. W. W. Price, a member of the well-known Canadian family, to hunt moose in his large preserves on the south side of the St. Lawrence, I lost no time. Thanks to the kind offices of my friend Mr. Frank W. Ross, arrangements were already made and waiting for my arrival ; thus I was enabled to set out on the following day. As a first step my hunter, Ed Atkins, and I travelled to Rimouski, where we slept the night, and in the morning started in a buck-board on a thirty-mile drive, the last stages of which lay through the bush. This was my firsi view of the Canadian forests, and I had the good fortune to see them at the most beautiful time of the year, when the foliage of the hardwood had not yet all fallen and each maple displayed its full glory of crimson leaves. 
As we drove we heard-to use Mr. Kipling's words"the monstrous female voices" of the fog-sirens piercing the light mists which overspread the river. It is, by the way, a curious fact that the noise of a siren, heard at a distance, resembles in some degree the call of the cow moose. All round the Canadian coast this fact has been noticed, and moose-generally young and unsophisticated beasts-have been, and continually are, killed upon the open seashore flats, whither they have been lured by the song of their strange charmer. In a word, the fog-horns have brought many a welcome joint of moose meat to vary the dietary at the salmon canneries.

Our objective was a log hut on the margin of Depôt Lake. All along the earlier part of the road we met with FrenchCanadian settlers, almost every one of whom carried a singlebarrelled shot-gun on the chance of seeing a covey of ruffed or Canada grouse, which at this season of the year are often found on the edges of the trail and forest paths. At the last house we happened to fall in with the warden of the district, Eleazar Hinds, and I arranged that he should accompany us, as he was familiar with the woods in which I proposed to hunt.

About an hour before sundown we arrived at a point beyond which the buck-board could not go, so shouldering our packs we began our four-mile tramp to the hut. Excepting where the trail was flooded by the workings of beavers, the walking was easy, and we had gone nearly half way when Ed found the track of a cow moose that had crossed only a short time before. Soon after dark we reached the hut on Depôt Lake, a spot which has since been made the headquarters of a shooting and fishing club. The hut proved most comfortable, being fitted with rough bedsteads, good stoves, and a small library of books, altogether a far more luxurious hunting camp than any to which. I was accustomed. 
Edward Atkins had been for eight years a Maine guide at the camps of his uncle, the well-known Will Atkins, who is said to give his clients more sport and to manage his camps more adequately than any other man in the same line of business. Ed proved to be one of the keenest hunters, and is certainly a good moose caller, and I liked him from the first, a liking which has been increased by the five other trips we have since then made together in Canada.

We had dinner, and were before long in bed, and, though we heard it rain in the night, we woke to find the morning splendidly fine. As compared with the woods among which I had just spent some weeks in Newfoundland, I was much struck by the height and growth of the Canadian trees, and especially of the grand hardwood ridges. The lake, which lay in front of the hut, was crowded to its very verge by the forests, and open spaces were few and far between. The country looked in all respects an excellent one for moose, and I was not a little glad to find myself well launched on a trip that had been dwelling on my mind with a good deal of persistency for more than two years.

We spent a lazy day, as Ed thought it wiser not to disturb the ground for calling, though at the same time he doubted whether the bulls would still answer at so late a date in the season (October I3th), and I am inclined to think they would not have paid much heed to a less skilful caller. During the forenoon, quite close to camp, we shot three ruffed grouse with a small .22, which we had brought for the purpose. All through our stay in the woods this rifle gave us a good deal of amusement, as it made hardly any noise and so did not in the least alarm any animals that might be in the neighbourhood, while the birds we brought down with it supplied many of our meals with uncommonly good spatchcock.

Before going further it may be well to correct some rather prevalent ideas upon the subject of moose-calling. 
There are persons who, having had no actual experience of this, in many cases, very high form of sport, criticise "calling" as an unworthy way in which to kill moose. Since the day of which I write I have hunted moose in every fashion-that is, by still-hunting in the woods, by calling, and upon the snow; and it is my opinion that calling can give the hunter a thrill almost unequalled in any other form of sport. It is true that the moose comes to the hunter and the hunter does not (as in the theoretically highest methods of sport he should) go to the moose ; but the science and the knowledge of woodcraft that can draw so shy an animal to accept the caller's voice for that of his mate raises calling to a high rank, at any rate for the hunter who himself uses the horn.

It must also be remembered that on such occasions the moose almost invariably " comes in" on the wrong side of the lake, and as the time at which he arrives is generally an hour and a half or so after sunset, he is in the shadow of the waterside trees, and the distance is often two hundred yards or over, it thus needs a clear eye and a steady hand to save oneself the sleepless night that a miss inevitably entails. Moose-calling may seem to the tyro a very easy way of "getting your moose," and so once in six times no doubt it is, but the reader will possibly understand my point of view more clearly if, without further preamble, I go on to describe the experiences which fell to my lot with the first two moose that fortune sent within range of my rifle.

About five o'clock, then, on the first evening I spent in the Canadian woods Ed and I launched our canoe on the little lake which we had chosen and paddled up towards the head of it, where the surface of the water was green with aquatic plants.

The sun had just sunk through the tree stems, and had been succeeded by the little cold wind which so often blows at that hour, when we landed, and Ed, taking the horn, gave 
the calls of the cow moose. In words it is impossible to describe these wild sounds, even although it was my fortune later to hear a cow singing her love-song at no great distance, so I will not attempt to do so. The noise is something between a bellow and a moan and is repeated three times, the final call being more prolonged than the others.

It would seem that for moose-calling the standing position is necessary, as Ed would never call from the canoe. To begin with, he never used the bull's call, as is generally done in Western America ; but then it is said, and doubtless with truth, that in Western America the moose is a much less sophisticated animal than his brethren of the forests of Maine and Lower Canada. Also the number of bulls is probably far greater in the districts where the bull call is so successful, and consequently each bull has to win his mate by ordeal of battle; whereas in Maine and Lower Canada the law which protects cows absolutely has been in force long enough to have brought about an immense increase in their numbers.

On the evening I write of the comparative stillness of the weather was greatly in our favour, and the calls must have carried quite three or even four miles, being aided in this by a high ridge near by, which caught and hurled the sound onward.

Almost immediately after the calls darkness came on apace. Five, ten, fifteen minutes passed; a squirrel hissed and chattered from a tree, an owl mournfully saluted the night, and the shadows of the woodland deepened round the margin of the lake. Then followed a silence till a musk-rat came swimming down, and suddenly, either seeing or winding us, dived with a click like a cork being drawn from a bottle; and then the owl once more.

Half an hour passed thus before Ed called again; another half-hour, and yet another. It was not until after the fourth time of calling that from far away we heard first 
the sound of a breaking stick and then the grunt of a bull moose. Ed quivered like a dog drawing on game. For twelve years he has been calling and shooting moose, and, being a true sportsman if ever there was one, he felt all the cool yet glorious eagerness of his kind.

"He'll be twenty minutes coming in, I dare say. He's a mighty mean moose not to have come earlier," whispered Ed. And indeed the light by this time was not very good, although the stars were struggling feebly through an army of clouds.

From the moment when we first heard the bull moose onwards the drama enthralled us, especially when a second actor, or, if you prefer it, the feminine interest, entered upon the scene. It has been said that the bull moose is monogamous, but this is certainly not the case, and on that night we had very good proof that he is not altogether constant. For presently from somewhere in the woods a cow called and the bull answered. Ed was much upset at this rivalry. "How can I get him away from her ?" said he ; " but I'll try."

Try he did, though it was slow work, the bull sometimes coming towards us at quite a fair pace, but at others wandering back. As he came closer Ed and I got into the canoe. We sat there for what seemed a hopelessly long time, until at last we heard the bull enter the water about a quarter of a mile away on the farther side of the lake. Ed did not dare to call now, but filling the bark-horn with water let it trickle into the lake through the narrow end of the horn. The bull almost at once began to work his way round by the head of the lake, which was lucky, as had he taken the other direction he must have winded us. He had about six or seven hundred yards to travel, and had not, as far as our ears could tell us-for of course we could see nothingcovered half the distance when the deserted cow also entered the water a little lower down. 
Now the two huge animals began to answer each other, while we, being by this time out on the bosom of the lake, listened to their matrimonial differences. We put into shore and again poured water through the horn to attract the bull's attention, after which we heard him approaching steadily, and paddled noiselessly to meet him. It was clear that he had advanced to the end of a small grassy or marshy point, which thrust itself out into the water at the head of the lake. Here he stood. We also paused, for we were within seventy or eighty yards. He grunted two or three times and began to plunge-at least, so we, listening in the darkness, imagined, for we heard him tearing his hoofs out of the soft mud. Under cover of these noises we paddled nearer, and soon we were within thirty yards. I imagined I could now see the animal's eyes, shining points in the gloom.

Unfortunately a light mist had risen from the surface of the water, which added to the dimness, so that it was impossible to discover what manner of horns the bull carried. Recognising this, Ed urged the canoe forward with a silent paddle, and carried us so close that we were within fifteen yards. The bull had heard something, for he advanced a step or two into the water.

I was now in a dilemma, for, though I had for some unexplained and unexplainable reason made up my mind that the animal was a fine one, I could see nothing of his horns but a whitish blur, which may, and probably did, exist only in my imagination. I had him covered all this time with my rifle, but was naturally unwilling to fire. The cow called repeatedly in a complaining fashion ; she was about a hundred yards away on the same shore of the lake.

In the province of Quebec the game laws only allow one bull moose under each licence, but as the season was already well advanced it seemed doubtful whether I should meet with another. Yet to shoot without seeing the head was manifestly impossible. The sky, under the influence of 
what breeze there was, appeared to be growing lighter, and I waited, straining my eyes at the dark bulk which was so close. Perhaps only a minute passed, though it seemed infinitely longer to me, and then the affair was taken out of my hands.

I have said that the lake was shut in by tall timber, and probably this fact caused an eddy of wind. I was aware of a touch of cool air on the back of my head, and at the same moment of a tremendous stampede in front and another to the right . . . crash, crash, crash.

"Hear his horns in the timber!" from Ed in a voice of emotion. The sounds continued for a few moments, the crashing of the gigantic deer as they galloped off among the trees, and afterwards dead silence, to be broken at length by the cry of an owl.

"Mean luck!" said Ed; "I'm sure he had great horns." We turned the canoe about and made the shore, then, lighting our lantern, walked dejectedly back across the hardwood ridges to our log camp. Such was my first experience of the Canadian moose.

I think we sat up till one o'clock in the morning talking it all over and trying to see how we might have bettered our fortunes. "He'd have been our moose if we had had a jack same as Crook used at — in — Province," remarked Ed; " but jacking's against the law."

In another place, and with quite another companion than Ed, I have seen jacking for moose practised, and I must acknowledge, whatever the ethics connected with the method may be, that it presents risks to the hunter as well as to the hunted. In order to " jack" the hunters choose a dark, still night, and having bound a lantern, the light in which can be shut off, upon a mast rigged well forward in the canoe, the man who is to shoot sits down in the bottom of the craft in such a position that the lantern when opened shines over his right shoulder and thus directly upon the sights of his 
rifle. The call is then given in the usual way, after which, if a bull "comes in," the canoe approaches him within twenty or thirty yards, or even nearer. The shooter then opens the jack, letting out a stream of light upon the darkness of the night. The moose at once, and almost invariably, charges, and, be it big bull, cow, or yearling, has in four cases out of five to be shot in self-defence, as the animal, maddened by the glare, will rush right aboard the canoe, and an upset in the eighteen-inch water which flows above the bottomless mud round the margins of some Canadian lalies is more than liable to end tragically.

Yet, though "jacking" is undoubtedly a poacher's trick, great sport can be had in summer when on chosen water. At that time of the year the moose are, as is well known, almost amphibious in their habits, and in the space of a couple of hours it is possible to "open " upon half a dozen of the great deer. If the sportsman carries no rifle he is within the law, and may safely expect to have a considerable amount of excitement. Lest I should be misunderstood, I may say that I have never shot at a moose by lantern-light ; still, I have " opened " on several, though I should not care to do so without a companion at the stern of the canoe who could be trusted to keep his head and do the right thing instantly under sometimes trying circumstances. The view of a bull moose by lantern-light is remarkable. The horns, the gigantic Roman nose, the little infuriated eyes, and the whole unwieldy, purposeful charge of I,200 lbs. of flesh and bone and horn, form together a picture not easily forgotten -at least, that is the testimony of all such as have seen the spectacle.

But to return to our camp of regrets. After wasting some hours in useless heart-burnings, Ed and I went to our beds of balsam boughs, and the episode of my first meeting with a moose was closed.

There is a certain period of variable length-sometimes 
it lasts but two weeks, sometimes three or even fourwhen, if the weather be fine, the moose becomes master of the situation. This period begins when calling ends-about the 6th to I2th of October-and continues until the first snow falls. It is a time of hoar-frosts and sunshine, when every stick in the woods is brittle and every leaf crackles under even the most practised moccasin. Tracking is difficult, noiseless approach almost impossible. Moose are killed at this time, but generally it is the hunter's luck rather than his skill which stands his friend on these occasions.

But once the first snow falls and lies the chances of the game veer round. After that nothing can move in the woods without leaving an open advertisement of all its doings and wanderings, and it is consequently easy to tell the number of moose upon any given piece of country, and even the approximate spread of their horns, by measuring the spaces between close-growing trees through which they have passed.

In this connection it may be noted that the range of a moose is very limited-more limited, I think, than that of the European elk. A moose lives, and in due season dies, within a comparatively small ring of country-a lake, a hardwood ridge, a thicket of alders, a little marsh, such is his environment ; and even if disturbed he rarely travels more than four miles, in which respect he differs from the caribou, who, once his suspicions are aroused, heads away at his mile-eating gait, and travels for hours and even days.

The movements of moose in bulk are slow-so slow that it takes as long as thirty years for a country to become well stocked. Thus in the old days, before legislation of a protective nature was thought of, the moose were entirely killed out in certain districts. The slaughter was committed in the winter, when the deer had "yarded," at 
which time the old bulls will offer battle if disturbed. Little chance had they against the Indian or trapper with his muzzle-loader, who, having discovered the beaten paths between the high walls of snow, set to work and shot them down in cold blood for the price of their pelts, the horns being abandoned, and the meat left to feed bear, bird, and wolf, while their slayer sought the settlement. In this manner the moose were killed out, and for many years the great hunting-grounds of the 'fifties remained deserted. Now, thanks to the enforcement of laws more or less adequate, the moose are finding their way back to their old haunts. First one bull is seen, then a couple of years later two or three, so that if the country is not much disturbed each year shows a slow increase, until the district may at length be classed as re-populated.

However, we have wandered far from the period just antecedent to the " first snow," when the floor of the woods is like a vast sounding-board that carries timely warning to the huge ears of Alces americanus. Thus light frosts and still days followed the evening which has been described, with occasionally a little wind at sunset-the very worst weather for our purpose-so that though we hunted by day, and evening found us at the calling-place, we saw no warrantable moose. More than once the tracks told their own tale; one evening a cow called, her weird lovesong echoing through the woods, and once a small bull substituted himself for his betters.

Continued ill-fortune at length drove us to change our hunting-ground, and we travelled north until we reached a small lake shaped like an hour-glass. Here a little tumbledown hut, so diminutive that the shortest of men could not have slept in it without discomfort, offered us shelter. We dared light no fire, for, in the first place, we were within an amphitheatre of hills where axe-strokes re-echoed, and, in the second, the veering winds would have carried the 
smoke along the ridges. Consequently, as the frost was by this time hard, we endured some cold.

A windy evening-for the lake lay high-spoilt our chances ; the next fell quiet and calm. Just before sunset Ed and I paddled across and called, not expecting an answer so early, but quite hopeful of getting one later. The canoe, in the prow of which I was sitting, was thrust in between two rocks, so that I might watch the south shore while Ed watched the north. The dusk was already turning to darkness, and not a sound had I heard, when Ed whispered, " A big bull has come in. If you can turn round, he's your moose."

I turned with infinite caution, and following the line of his extended arm saw in the black shadow a whitish blur - the horns of the bull. He was about one hundred and fifty yards distant, and standing so still that I fancied he had heard us. I did not dare to risk a whisper, but, making out as I thought the huge bulk of his body, fired. He did not move, so I fired twice more, each time aiming for the lungs, or rather where I judged the lungs to be. The third cartridge stuck. I tore at it with my fingers, while Ed said, "Quick; give him another!" Before I could extract the cartridge and do so the moose had walked back into the wood at the lakeside from which he had emerged. He made no sound, but both of us were pretty sure all was well, since we were agreed that we had heard the bullets tell. Indeed, we lit the lantern and went to look. All that we found, however, was a series of tracks leading across a marsh and losing themselves upon a high ridge beyond it. Even then I felt certain that I had held straight, and that on the morrow we must find a bull dead and at no great distance.

It was a chance remark of Ed's which awoke me to a knowledge of the full depth of the tragedy. "When, before you turned, I saw him come out broadside on, heading to camp_-," he said. 
"Heading to camp! Are you sure?"

"Yes," replied Ed.

"Then we'll never see that moose again, Ed!"

"Why? How ?"

"Because I made him out to be heading the other way, and my shots must have passed in front of him!"

"Oh, why were you not turned round before he came in? He was our moose; that's the meanest thing ever happened to me in the woods!"

Well, there was no help for it; regrets were useless, and without more talk we retired to rest. I do not think either of us slept much. With the first dawn we were in the canoe, and before it was light enough for proper examination were upon the scene of the fiasco. It is enough to say that we found ali three bullets in a pine tree.

So much for misfortune. I have described these two incidents with the idea of showing that moose-calling has its difficulties, the chief being the semi or more than semi darkness in which the shot is taken. Frequently the animal must be fired at when two or three hundred yards away, as he so rarely answers the call until after the gloaming, when every instant makes the light less favourable, and to shoot the moment the bull appears is very important and necessary.

Perhaps it was disappointments of this kind that originally suggested jacking, by which trick a moose can be shot on the darkest night. Yet I am not sure that success in big-game shooting, in retrospect, is so interesting as occasional failure. Finality kills imagination, and it is ever the finest head whose horns we never measure.

Imagine now a beautiful afternoon in another late October. On the right runs an historic river, on the left scattered patches of pine and juniper dot a tawny ridge, the leaves are turning, for Kabibonokka had

" Painted all the leaves with scarlet, Stained the leaves with red and yellow." 
Accompanied by Ed, I was walking down a faint trail which led, for about a mile, beside the high banks of the river. We had walked some fifteen miles, and far behind us followed a buck-board waggon with our effects and canoe loaded upon it. The buck-board was in charge of a small Frenchman; now and then his voice, as he argued with or urged forward his horse, faintly reached us. It was our intention to push on as deep into the country as possible, for which reason we carried the canoe. Only an hour before I had loaded my rifle on the off-chance of a shot. The day was unfavourable, as a light cat-ice covered the pools and our advance could be heard.

We had arrived at a point where the trail led right over a high bluff before leaving the river. The, country was fairly open, so that we were both keeping a good look-out. As we descended the bluff I saw something move behind a thick bunch of spruce about a hundred yards ahead. The next moment a pair of huge horns and the large head of a bull moose were thrust into sight. I saw at once that if he turned he would be lost to us, as the growth in that direction was close. He had evidently been taking a siesta behind the spruces, and had been awakened by the sound of our approaching steps grinding upon the thin ice.

The moment my rifle covered him I pressed the trigger and heard the bullet strike. The great animal sprang forward across the trail, which was for all the world like a ride in an English park, receiving a second shot as he did so. He disappeared, and I turned to run to the height of the knoll in order to command the river. There was no need for this, as in another moment I made out the bull just as he was in the act of falling. We ran up. He was not dead, and indeed got to his feet and attempted to charge, an effort which was cut short by a last shot in the chest. We stood beside the dead giant and admired the fine palmated horns, which carried twenty-two points and spread fifty- 
two inches. To our surprise we found a third horn growing from the centre of the forehead, but it had unfortunately been broken off earlier in the season, so that only a stump remained. The brows were very good indeed and the shovels cupped and broad.

Presently the Frenchman and the waggon put in an appearance. He was greatly surprised, and vociferated a great deal concerning "l'orignal magnifique." That night we camped beside the moose and, before we slept upon his hide, thoroughly discussed my amazing good luck, the extent of which we only realised later when hunting caribou over the same country in the "first snow," at which time, during a week's walking, we saw only two moose-tracksthose of a cow and a calf, the widow and offspring, perhaps, of the big bull.

Only on one other occasion have I had equal or greater good fortune, and then a moose was once more the victim. I was paddling up a river and, owing to a rain-shower, landed upon a sandy spit under a high bank. When the rain cleared off, before launching the canoe again, I thought I might as well climb the bank and have a look round. On doing so in a very desultory way I at once saw a bull moose standing facing me about a hundred and fifty yards away. As he had not seen me I was able to sit down and rest my elbow upon a stump which lay embedded in the marshy soil, and so to take a quiet shot, which was effective. But for the rain I should never have dreamed of landing from the canoe at this spot.

On another occasion while on a trip we were camped in a country where both caribou and moose were to be found. One night on returning to camp a French-Canadian, who was with me, informed me that he and his companions had seen a large bull, a cow, and a calf upon the other side of the lake. As I had returned to camp by daylight more than an hour before he saw fit to tell me of the fact, I fear I was 
rather sceptical, in spite of his promising to lead me to the tracks in the morning - the more so as the night, which had just fallen, gave promise of snow. The end of the matter was that at ten o'clock that night the indefatigable Ed and I, accompanied by our French-Canadian cook, broke the thin ice on the lake and went off in the canoe to find the tracks and to verify the story by lantern-light. It is but fair to say that we did find huge slots, and spent the next day in following them up. So far the cook proved himself a man of his word, but in the matter of the size of the bull's horns he erred strangely. Perhaps they are bigger now, for they have had time to grow.

I often wondered at, and often regretted, the prohibition which obtains all over America against the use of dogs in moose-hunting. I do not mean by this the use of a pack or of a single loose hound, such as in Sweden is used to run down and bay the great deer, but I refer to the harnessed hound of Norway. There, as is well known, 90 per cent. of all the elk killed annually are killed over dogs. The presence of a hound adds enormously to the enjoyment of the hunter, and as the animal is on leash it certainly does not frighten or disturb the elk or do any damage.

A blank day in America, spent as it must be in walking over the endless hardwood ridges, is a dull affair, the more especially as the hunter knows that luck rather than skill is needed to crown his efforts. But a blank day in Norway may be full of excitement, for there the hound is a living barometer, giving warning of the nearness of the elk, which he can wind at a great distance, often leading the hunter to a fresh track a mile off, so that when one knows and understands a dog's ways dulness is finally driven away. Then there is no pushing on through interminable forests in a comparatively blind fashion, but every step is taken with a view to the next, and for the hunter who goes alone and works his own dog the sport is a splendid one indeed. 
The difference in horn-growth between the American moose and the European elk is strikingly great, certainly greater than the difference in size and weight of the animals. Anything spreading over forty inches may in Norway be termed a good head, as is anything over fifty inches in Canada; but the number of fifty-inch heads shot in Canada is far greater in proportion to the total killed than is that of forty-inch heads to the total killed in Norway. Yet as far as my own observation goes-to which I may add the experience of two of my friends-the hoofs of an elk are, curiously enough, very noticeably larger than those of the moose.

One point of difference may, I think, be fairly noticed. The American moose seems when wounded to be far more apt, if not to charge, at least to defend itself, than is the elk. This, of course, is probably due to the fact that in the summer months, when the farmers have their cattle upon the mountains in Norway, the elk must often receive a taint upon the wind, whereas in Canada only the lumbermen and an occasional prospector invade, out of season, the solitude of Alces americanus.

As to the charging propensities of the moose in daylight my guide, Edward Atkins, has definite views, and as he has been in at the death of probably as many moose as any man of his age, and is, moreover, a very accurate observer, his evidence is entitled to respect. In his experience the tendency of an unwounded moose to charge is practically negligible, though instances to the contrary have occurred in his own knowledge. A wounded or cornered bull will, however, generally do his utmost to make things uncomfortable for his pursuer. As an instance in point, my friend Mr. G. M. Gathorne-Hardy, when hunting in Canada in I907, fired at a large bull moose which fell to the shot. As the animal lay quite still he went towards it, but when he was within a few yards it rose and made a 
most determined charge, which he could hardly have avoided had he not been able to turn the animal slightly with a shot in the chest.

Since the discovery of the variety of moose now known as Alces americanus gigas in the Kenai Peninsula of Alaska. it has become a recognised fact that these enormous animals exceed in size the moose of Lower Canada in about the same degree and proportion as the moose of Lower Canada exceed the elk of Norway. There is, doubtless, a more than fair sprinkling of seventy-inch heads in Alaska, though few of these are probably finer than the grand sixty-six and a half-inch head shot by Mr. F. C. Selous upon a western spur of the Rockies in I904. But from recent statistics it would appear that the last few years have been very favourable in the matter of large heads in Eastern Canada. Among individual specimens may be mentioned the sixty-eight inch head shot quite recently in New Brunswick, and a very fine sixty-three and a half-inch head which I saw at a taxidermist's in Ottawa.

Mr. Price also shot a moose spreading over sixty-three inches in 1908 near Rimouski. This head, which I had the pleasure of examining, was a very fine one.

There are many who profess the accomplishment of moose-calling, but when put to the test in the woods very few are found to be really experts. In Alaska and the West hunters imitate the grunt of the bull which he sends through the forest as a challenge to his rivals in love and war; but it is rather in the United States, in Lower Canada, in New Brunswick, Quebec, and Ontario, that calling really becomes an art ; for in these latter places the hunter usually imitates, not the short, harsh grunt of the bull, but the three longdrawn, modulated calls by which the cow moose makes known her whereabouts to her mate.

During his many seasons of calling Ed Atkins has naturally had one or two strange experiences. Once, for in- 
stance, he received no fewer than four separate answers to a call ; and on another occasion, when calling at one of the home camps of his uncle-the well-known Will Atkins, of Maine-a bull was coming in satisfactorily when the large dinner-bell tolled in the hotel some miles away, a sound which effectually turned the moose back.

Calling is no longer much carried on in Maine, where the season for moose does not open till the I5th of October, so that the pick of the Maine guides go to practise their art in New Brunswick, where moose are plentiful and where the season opens on the I5th of September. About this date moose usually begin to answer, and for about a month a bull can be called in by any one who is skilful enough to produce an adequate imitation of the cow's voice. In some seasons the bulls answer much earlier, as was the case in I908, when Ed called in a good bull on Lake Edward on the evening of the and of September. The horns of this animal were still in velvet. Generally if the calling season begins early it ends early, lasting in all about a month to five weeks. In I906, when we were calling on the south side of the St. Lawrence, our last bull came in on the 2Ist of October, but there is much more difficulty in bringing them in so late in the season.

The call of the cow moose is said to consist of three distinct notes, long dwelt on, with a pause of about a minute between each. It is a curious fact that, although I have been fortunate enough to hear cows call on many occasions, I can remember only one on which the three accepted calls were given. This was at Lac Pino after dark. On the other hand, one evening in I908 a cow moose suddenly called about a mile away. I immediately travelled in the direction of the sound, and when I was quite near, certainly within a quarter of a mile, the cow called seventeen times almost without a pause. I gradually approached within a hundred yards of the cow, who by this time had 
been joined by a bull, and at this lesser distance found her calls resolved themselves into a harsh, throaty roar, ending in a prolonged moan. Though not loud, the sound seemed absolutely to vibrate through the air, and on a still night (and no other is of much use for calling) would travel for miles. To reproduce this bellow from a human throat is, as I have said, not a readily-acquired attainment, and in Maine the counterfeit call must be given to perfection, for the moose of that region are cautious. Indeed, the sense of hearing in the moose is extraordinarily developed; the large palmated horns seem to act as sounding-boards, and the least irregularity in the call, instead of beguiling the bull, sets every animal within [hearing on the qui vive with as much certainty as the echoes of a human song.

It is a strange fact that calling is not attempted in Norway, for there also, though they are more silent, the cows do most undoubtedly call during the rutting season. The Norwegians have named the sound lokke-tone, and my friend Mr. A. C. Gathorne-Hardy heard a cow call repeatedly one evening when he was hunting in the North Trondhjem district.

There is one further point upon which nothing too strong can, it appears to me, be written or said. All over Eastern Canada, at any rate, the taxidermists and furriers sell moose heads at prices ranging from $£ 20$ to $£ 50$. For my own fifty-two-inch head a taxidermist who did not know to whom it belonged offered $\$ 200$ "in the raw." Those who buy heads in this fashion are generally rich parvenus or so-called sportsmen, who, having started for the woods with the same publicity which pervades their lives, do not relish returning to their native towns without a trophy. What manner of man it can be who is thus content to buy and to lie is a difficult question. Certainly on all counts, as one of my hunters said, "He don't deserve no consideration, though his dollars is sound money to us." If such 
persons must buy, one would imagine they would at least only buy full-grown heads; but as a matter of fact this is not the case, for in some parts of both the States and of Canada even a two-year-old bull is worth $£ 20$. "Anything with a head-skin to it," as Ed remarked in wholesome disgust.

It would appear to be an extreme step if the exposure for sale of sporting trophies should be forbidden by law, save to museums. Yet the result would be admirable in every way, and would almost certainly do more for the preservation of big game than the appointment and up-keep of any number of new forest wardens. Nor do I suppose that there is any hunter of note or skill who would not support such a measure by all means in his power.

Take, for instance, the case of the moose-for it is the moose which suffers most at the hands of the trophy buyers - surely he deserves better treatment in this respect than he receives. As far as extinction is concerned he has nothing to fear from the bonâ fide hunter, but he has all to fear from the wandering and masterless men who invade the woods. Such would turn everything that lives into dollars. You will even hear such a man say " I lost $\$ 50$ to-day through them bad cartridges," which means that he wounded, but did not get, a four-year-old moose.

If a law were brought in and passed forbidding under heavy penalties the sale or exposure for sale of all horns of moose or caribou, the promoters of such legislation would be called blessèd, not only by all true sportsmen of to-day, but very much more by the coming generation. Such a law would, as a matter of fact, be a far more effective measure than the extension of the close time to mid-October, which obtains in some states and provinces in order to prevent calling. But calling will not do much harm to the moose for two sound reasons-one of which is the lack of good callers, and the other is that after the first week the master bull of a 
district rarely answers the call. It is generally one of the less successful candidates for that honour, and the killing of such to a moderate extent is not an unmixed evil. Of eight bulls called in I906 upon the ground I hunted two, both spanning over fifty inches, were shot, and all were, as far as could be seen, warrantable beasts.

The killing of moose after a date when the snow is really deep should also be absolutely prohibited. Canada has done great things for her big game during the last decades; it is to be hoped that she will not pause now, but will continue on her course and carry the wisdom which she has exercised in her woods into the shops of her towns, so that soon her moose and caribou will no longer bear on their antlers a price that means a sentence of death from any wandering rifle. 


\section{CHAPTER VIII.}

A SEPTEMBER TRIP UP THE GANDER, NEWFOUNDLAND.

$\mathrm{H}$

AVING already made two October, or second season, hunting-trips to Newfoundland, I determined in I906 to spend the early or September season in that country, for caribou-hunting in September is carried out under entirely different conditions from those which obtain later in the year. In October all the hunter's efforts are directed towards intersecting the line of migration of the herds, which are then moving south; whereas during the earlier month migration has hardly begun, and the chance of sport lies in finding and hunting "summering" stags, that is, stags that have spent the summer in defined districts, generally in the near neighbourhood of some river or lake. A stag, while growing his horns, seems to remain within the limits of a comparatively small area, from which he does not move until he goes out to meet the does late in September, or more generally in October. Stags invariably rub in their favourite summer haunts. The horns of the best stags are generally free of velvet by the $7^{\text {th }}$ of September, or even earlier. Trees torn and broken by rubbing are to be seen occasionally during the last days of August, but in an ordinary year the bulk of the stags seem to rub between the 5 th and Iath of the following month. This applies to the country lying south of the railway.

The shooting of good stags in September is, in many ways, a much more difficult matter than it becomes later on. 
The method of hunting is naturally altered to suit the circumstances. The first step is to locate a shootable beast, then to watch and wait for his appearance, for at this period the stags usually pass the day in the thickets, only wandering out of their shelter by chance, or to bask in the sun, or to drink. Next, a caribou in thick timber is by no means so easy a quarry as he frequently proves after he takes to the open. And lastly, the conditions of woodland hunting often leave but a very brief instant for judging of the head and shooting. Besides, it is obvious that the hunter's opportunities will probably fall far short, as far as numbers go, of the chances in October, when the deer are collected together about and upon the line of migration.

Having made up my mind to try a September trip, I left England early in August, as I wished to have some fishing before the commencement of the shooting-season, for which my friend A. C. Gathorne-Hardy had agreed to join me. Only three years had elapsed since my first visit to Newfoundland, but on reaching my old ground of Terra Nova Lake I found evidences of a great change. In I903 the influx of "sports" had been insignificant; in Igo6 it had increased, though even then it had not attained to anything like its present magnitude. The "opening up" of Newfoundland came suddenly and swiftly, and was aided by an enterprising native taxidermist who had then begun to organise, and I believe still continues to organise, little armies of sportsmen at $\$ 200$ a head, all found !

On my former visit when I travelled up the Terra Nova Lake I had had the country to myself, but in August I906, while camped with my mother on Woody Island by the Narrows, which form the highroad to the interior, I saw, with regretful yet not altogether selfish eyes, five parties of "sports" pass away into my old hunting-ground.

At the time I made my camp upon Woody Island I had not come to any decision as to where I should hunt 
in September; whether to pay a second visit to the Terra Nova country with the intention of penetrating to further regions than I had hitherto reached, or to try my luck on the Gander River, which was new ground to me. Hardy, who was to be my companion, had left the choice in my hands, and after I had seen five boatloads of these boisterous voyagers hauling away out of sight over the grey-green lake, the trouble of making up my mind on that head no longer bothered me: I unhesitatingly made choice of the Gander River.

Thus it came to pass that, on a pouring wet morning, the $4^{\text {th }}$ of September, Hardy and I turned out of the train at Glenwood, the station near the Gander Lake. All things considered, there can be few more dejected-looking spots in the world than Glenwood. Its few thin-chested wooden houses stand dolefully alongside the metals; a lumber mill and some sheds make an untidy background; the earth is covered with splinters "of wood and sodden with sawdust; through the valley, which is spanned by a trestle bridge, the Gander rolls in quick water over a stony bed. The romance of its name, Glenwood, has nothing to do with fact; even the beauty of the woods is absent, for fire and axe have devastated them, and the place, standing exposed to the wind, is both bleak and cold.

Presently we discovered that Jack Wells and his comrades Bob Saunders and Ned Sweetapple, having arrived the previous night, had set up a tent on the lake edge to await our coming. Moreover, the men had "packed" all our outfit to this spot, as it was close to the wooden wharf from which the steamer owned by the Newfoundland Timber Company starts. Mr. Crowe, the manager, had kindly given us permission to make use of this steamer. Owing however, to the arrival of a large consignment of logs from Gambo and a consequent pressure of work upon the employés there had been some delay in the preparations and we did 
not start until eleven o'clock. Just as we untied from the wharf, Reuben Lewis, the chief of the Micmac Indians, appeared and asked us to take him with us as far as the lake head. This we were delighted to do, and on the way had some very interesting talk with him. He was accompanied by his nephew, a lad of ten or twelve, and had come down to Glenwood to sell deer-meat, leaving his sister, Soulis Ann, in a teepee at the upper end of the lake.

This Reuben Lewis has been for some years the chief of the Newfoundland Micmacs, a branch of the Nova Scotian tribe. $\mathrm{He}$ is an intelligent man, but insignificant-looking in person, and has at one time been severely mauled by a bear. His people have parcelled out the Newfoundland interior into hunting-grounds for themselves. Thus, Joe Jeddore hunts Middle Ridge; Stephen Bernard the Mount Sylvester district; Reuben Lewis, Kagudek; and so on. During the spring and summer they are to be found more or less regularly in the Conn River Settlement on the south coast. In August they travel up into the burnt timber, and throughout the winter each man patrols his trappingground. They number in all some one hundred and fifty souls. The duties of Reuben Lewis appear, for the most part, to be those of an arbitrator, and should any dispute arise he gives judgment upon it, and that judgment is accepted and takes full effect.

The Indians do not greatly incommode the hunter who wants to shoot good heads, as up to very recent years they have not been in the habit of shooting for any object but that of procuring meat. But the good prices that are now offered for trophies will, I fear, spell the death warrant of many a fine stag. It must be remembered that the Indian, unlike the sportsman with a licence limit of three heads, does not consider himself bound by the game laws of the country, but shoots as many as he likes. The unfortunate result of this in the long run need not be pointed out. 
A good deal of nonsense is talked in connection with this subject as to the inherent right of the Indian to shoot deer without being bound by any game-law limitations, as are sportsmen who come for pleasure or settlers who hunt for meat. But the game laws are framed in the interests of future generations, and if impartially enforced would actually tend more to the advantage of the Indians than of any other class of the community.

The policy of many of those who make the game laws in our colonies, in America, or indeed all the world over, has always seemed to me to be extraordinarily short-sighted. Take Newfoundland as an example. The number of caribou allowed under the licence to each sportsman is three; to each settler five deer in every year; but this law imposes small restriction on the settlers in the country and practically none upon the Indians, who act as if it did not exist. As to the settlers, when a man has shot his own five he goes on to shoot for his friends, and if either Indian or settler sees a stag with a fine head he shoots it for its horns, not to keep, but to sell.

As I have said in a previous chapter the only possible way even to partially stop this wholesale slaughter would be to forbid the private sale or exposure for sale of trophies in shops. This should be the first aim of any code of game laws, the more especially as the demand for trophies is becoming greater and greater every year. Nor would it bear hardly upon the settler or the Indian, for little enough of the ultimate price falls to their share; the bulk goes to fill the capacious pockets of the middlemen taxidermists, and until these facts are taken into account by the framers of game laws there will be no real game protection.

How can there be, when every stag with a good head is shot down? It will be contended that this is precisely what the sportsman does. True, but the number he can kill is closely limited, and he shoots according to certain 
rules-the rules of the game. He is the man who brings not only money into the country, but knowledge, and also a very real, if to some extent a selfish, interest in the maintenance of wild animal life. Yet it is practically always against him that modern game laws are directed, instead of against the pot-hunter. The latter is the man whose works live after him. He has already devastated more than one country. Antlers and hide mean so much money to him, no more; the extinction of a species is no cause of regret to him-his concern lies solely with the dollars. But he has a vote, and so the politicians pamper him.

The game laws of Newfoundland are as sound as those of any country I have visited. They do not permit the guides to shoot when accompanying a sportsman, though of course at other times each guide has his right, as a citizen, to kill five deer. This is an excellent regulation, for when the sportsman has shot his three heads he can kill no more, and may as well leave the country. In other circumstances he might buy from his men their right to shoot the five each to which they are entitled, and a certain number of sportsmen would undoubtedly do so-an evasion of the law which could only lead to bad results. If Newfoundland would but add an absolute prohibition, under a heavy penalty, of the sale or exposure for sale of the trophy of any indigenous wild animal, her game laws would be as nearly perfect as one can expect such laws to be. Perhaps, however, they might be altered in one other point. A fio licence permits the foreigner or visiting sportsman to shoot three stags. This places the person who goes up to Howley and in two days shoots that number of prickets as the deer cross the line on their migration on the same footing with the man who spends six weeks in the interior looking for three fine heads. If, instead of this, the law allowed a stag for every week spent hunting, the law would be more just and fewer stags be unworthily slain. Incidentally the 
country would benefit, as the hunter who goes into the interior spends, say, fIoo as against the fIo note of the railway sportsman.

To return to our start in the steamer from Glenwood. After proceeding about three-quarters of a mile down the lake we put in to land and took up a load of fuel, which did not occupy many minutes, we and our men working with the steamer crew. Only the Indian chief held himself aloof. As the wood was brought aboard it was stowed below by one of the Timber Company's men, and in the midst of the loading a log was thrown down which struck this poor fellow on the head. As the log was a heavy one, the least we expected was to find that he had got a nasty knock-out blow, but to every one's surprise, after a dazed moment and a little king's English, he began to work again.

The Gander Lake is a fine stretch of water, wooded to its borders and shaped something like a star-fish, of which one great arm runs up towards Benton.' We left this to the south-east, and about three o'clock disembarked at the lake head. We brought off the canoes and the outfit and loaded for our start up the river, only waiting to make a fire for a cup of tea before setting out to take advantage of the small amount of daylight left. While the men were busy Hardy and I paid a visit to the Indian teepee. We photographed Reuben and the teepee; then, being introduced to Soulis Ann, we begged for the honour of taking her likeness also. She was by no means unwilling, but, alas! insisted on arraying herself in a black tightwaisted store-dress, which, had she but known it, was far from an improvement upon her more picturesque everyday attire.

We promised the Indians copies of the photos, and entertained them at a meal of bread, cheese, and tea, after which we bade them good-bye, and distributing ourselves 
in the canoes, one nineteen-foot and two sixteen-foot, we paddled away.

For the next five days we rowed against a very heavy stream, for in the September of I906 the river was at least a couple of feet higher than is usual at that season. There were two or three small rapids, but nothing to give us much trouble until we reached Rolling Falls, where a portage became necessary. Here, in the soft sand, we found the trail of a party of four hunters who had left Glenwood the previous week. Their presence ahead of course destroyed our chance of seeing many deer, as by the tracks it seemed that two of the party always walked along the bank, and even days old footsteps serve to turn any deer that cross them. Indeed, for many days we saw but one caribou, a doe, which appeared as we were passing the shores of Birchy Island.

Bob Saunders alone of our party had any knowledge of the Gandei. He told us that on his previous trips up the river stags were almost always to be found, their haunts being on the sandy shores and on the sand banks in the riverbed. But now, owing to the height of the water, there was no sand to be seen anywhere, and our only chance lay in coming upon a stag actually crossing the stream. The volume of water drew from Saunders one of his characteristic remarks: "If this be the tail of the Gander, I wonder what it'll be like when we comes to the beel of he!"

He was a cheery old fellow, never disheartened and full of quaint talk. His system of therapeutics was queer and simple, but perhaps not to be recommended for general use. For.instance, as a boy, when not feeling very well he was, he told us, in the habit of dosing himself with gunpowder. When gently admonished, he assured those in authority that they were quite mistaken as to the possibly dangerous results, as it made him well very quickly. This may have been so. At least he did not die. 
After some three days spent in struggling against the fast dark current, we reached the neighbourhood of Cooper's Brook, where we found another Indian teepee-this time empty-and a little further up a birch-bark letter in a cleft stick, from one Nicolas Jeddore, a Micmac, stating to whomsoever it might concern that he came from Conn River, and having travelled east to Child's Pond and Baby Lake was now on his way back to Conn River again. The Indians often leave such letters, set up in prominent positions, for the information of their friends and comrades.

Up to this time we had seen no open country, the woods growing thickly to the very water's edge; but as we approached Migwell's Brook the banks began to show signs of change. At the outlet to the Brook we caught three good ounaniche, the only fish caught on the whole trip.

After this followed a period of rather dull toil. The rival party was still ahead of us, and at the most likely spots for game on the bank we were sure to find the inevitable and irritating traces of their boots. Sometimes the track of a stag was near by, but the signs showed that in most cases the deer had turned back into the woods. Reuben Lewis had told us of a spot which he said was one of the best crossing-places for caribou on the river, or, in fact, in the island. This place was Serpentine Hill, a cliff some two or three hundred feet high, bare of trees and covered with asbestos. From Migwell's Brook we had to work up-river by wading; at noon we grounded our canoes under the cliff, and leaving Ned Sweetapple to prepare a meal the rest of us climbed the peak to have a look round.

The prospect was most satisfactory. We were at last clearly in good deer country. We could see for four or five miles, and the low woods were broken by outcrops of hard mossy barrens, such as the caribou love to haunt. That was on the north of the Gander. On the south the country 
was still more open, stretching away for thirty miles to the rocky wall of Middle Ridge.

In the afternoon Hardy and Bob Saunders took the south bank, while I, with Jack Wells, hunted the line of ridges to the north. We saw seventeen deer, but not one warrantable stag until we were back in camp. It was growing dark when, about six hundred yards up-stream, a beautiful stag appeared, and accompanied by two does began to cross the river. I seized my rifle, and getting under cover of a line of rocks commenced running towards the stag, but before I had got far I slipped among the wet stones and came heavily down upon my knee-cap. When I was able to hobble along again, the stag had vanished. The light and distance made it hard to judge of this stag at all accurately, but I managed to get one good look with the telescope, and I was certain that he had an excellent and rather curiouslyshaped pair of bays.

It is this fact of the sudden appearance of a stag which makes September hunting rather more difficult, and certainly more interesting. As the animals emerge from the thickets, or as one catches sight of them through the trees, it needs instant decision as to whether the head is what you want to shoot, and, after that, quick shooting. Caribou antlers are not easily judged, as they look very different from different points of view. To be misled into shooting a poor head is one of those mistakes for which a man can never quite forgive himself.

As an instance of the deceptive impression one may gain, I remember a stag which I disturbed from a drogue of spruces, and which I thought showed the best horns, and with the greatest width between them, that I had ever come across. I fired at once, before the stag disappeared, but on reaching the trail found no trace of blood, even after following for some distance. I was certain that I had badly missed the chance of a lifetime. I made up my mind that 
the antlers carried at least forty points, and measured forty inches from tip to tip inside the tops-a very head of heads ! Following the tracks for another two hundred yards, in the wild hope that the stag might stop and look back, I came upon him lying quite dead in a little marshy hollow. The stag, it is true, was an enormous animal as to his body, but he was old, and the horns were not what once they had been. They numbered, indeed, but twenty-five points, while the span was thirty-seven inches-a warrantable and rather curious head, but no more. Yet if that stag had happened to get away my imagination would always have given him forty points, and an undying regret. Undying regret is hardly too strong an expression. In my own small experience I have found that the only cure for such a loss is to obtain an indubitably better head. That, occasionally, more or less removes the sting. This confession may leave the hunter open to the charge of lacking the sense of proportion. To miss or to kill any single animal is, after all, a small matter. The hunter recognises this fact in the abstract, yet the keener he is and the greater his experience the more strongly he realises that no game is worth playing into which a man's whole heart does not enter.

Hardy on that day saw seven deer, but nothing worth shooting. During the next fourteen days we both learnt a very fair amount about September hunting, but neither of us fired at a stag. The few we gained sight of were young animals, and not such as we wanted. During this time we went up-river and visited our rivals, who had secured four stags, none of them very remarkable.

Just before arriving at Burnt Hill, near the " beel of the Gander," in Bob's phrase, we began to pass through forests that had been destroyed by fire, and in which the Indians find black bear. To go further was useless, so we determined to hunt in the beautiful country that we had seen 
between Little Gull River and Migwell's Brook. To this we accordingly returned.

One evening at this time, as we sat by our fire, which we had made on the bank of the river near Serpentine Hill, we detected an odour which was certainly more curious than pleasant, and which we at first attributed to our sealskin boots that had not been adequately cured. But after the offending boots had been removed beyond the sphere of our senses the smell remained in its original force and seemed to come from the back of the camp. A short exploration in that quarter showed us good reason for it. An Indian had camped there some time in the previous winter. We found his blanket, rotted with wet, his cup and his knife, and the bones of a deer. Of the Indian himself no sign remained. He may have deserted his camp all standing, though such an act would have been at variance with the characteristics of his race; for an Indian will walk any distance to recover his goods and chattels. On the other hand, it is possible that the man died in the camp and that his kinsmen had removed his body for burial, leaving his belongings in the place of death, which with many tribes is held to be accursed. Or he may have fallen a victim to some accident while hunting and crept away to the nearest thicket to die in its shelter. However, all this is mere conjecture, and only one fact is certain-that anything more lonesome than that deserted camp, with its few poor rotting or rusty implements beside the ashes of the camp fire, can scarcely be imagined.

We had now been nineteen days without firing a shot, and, with the exception of the stag which crossed the river by Serpentine Hill, without seeing a really fine specimen, so it became necessary to hold a council of war. We decided to split into two parties, Jack and I going into camp near Little Gull River, while Hardy and the two other men "guarded the higher passes of the stream."

When we had packed Jack's outfit and mine into the $7 a$ 
small canoe, I sent the former to paddle down, while I started to walk along the bank of the river. Hardy accompanied me for a part of the way, and we had hardly turned the first bend when I went over the bank to examine a deer road that showed some fresh tracks. As I returned I heard Jack whistle softly. He was in mid-stream pointing down-river, and there, just beyond the bend and hidden from Hardy by an outcrop of boulders, a large stag was in the act of entering the water from the farther side of the river. The instant he knew that I too had seen the stag Jack paddled into cover. Hardy, also catching sight of the stag, crouched among the rocks.

The stag stood for a moment on the bank. Hardy looked round, and I, knowing the head was a fine one, was glad to see him raise his rifle for what was a longish shot, a little over two hundred and fifty yards. The first bullet hit, and at the second the stag rushed forward into the river hock-high, splashing the water over his back in a grand rush, and within fifty yards fell dead.

Jack now thrust out into view, waving his paddle, and we ran down the bank until we were opposite the spot where the dead animal lay. Then Hardy, eager to examine the horns of his first caribou, without waiting for the canoe, waded into the stream, which here was about a hundred and fifty yards across. There was no mistake at all about the horns of the stag, which carried a most beautiful palmated head of thirty-three points. Indeed, but for the fact that one brow antler was represented by a spike, the head would lose little by comparison with the best.

We now hoped that the luck had at last turned, for we had begun to fear we might be obliged to finish the season empty-handed, as neither of us wished to kill the poorlygrown heads which we had hitherto seen. That year of Igo6 was a less than average good year for horns in Newfoundland. Occasional bad seasons are no doubt the result 
of a severe and late spring, during which the lack of proper food affects the horn growth in its early stages. Thus I904 and 1905 were very lean years, and 1906 not much better ; but in 1907 , and more especially in I908, the milder weather caused the stags to grow magnificent antlers.

After this Jack and I went on our way, and finally set up our camp about half a mile above Little Gull River. We chose a spot peculiarly suited for September hunting, putting up our lean-to in a little thicket on a promontory, from which we had a view of the river-bed both east and west. On the farther bank a continuous wood of spruce and birch extended for miles, while behind us lay great expanses of young timber interspersed with marshes and barrens. Out of the birch-wood opposite several deer-roads descended to the water's edge, among them some veritable highways, but, as there was no sign of migration, only the few stags that had summered in the vicinity were travelling them.

The same night, as we were lighting our fire, a young stag of about twenty points walked quietly out of the birches and began to cross the river, but in mid-stream caught the wind of our fire and at once turned and rushed back into the woods. On the following morning we were up at dawn and hunted all day in the direction of Red Indian Lake, but our eyes were gladdened by nothing more exciting than the sight of a couple of does. About four o'clock in the afternoon we climbed up a high hummocky barren, surrounded by thick woods, and sat in the warm sunshine smoking our pipes in, it must be owned, a very depressed state of mind. Our eyes ached with staring through the glasses at every patch of grey or white among the green, yellow, and crimson network made by the woods and mosses.

As evening began to fall I came to the conclusion that the river by our camp would give us a better chance, so we set out on our return, and, contrary to our custom, con- 
versed as we walked. Jack was in the lowest of low spirits, and suggested gloomily that the stags had all " gone on the Labrador"! This keen fellow's one fault is that he grows dejected unless he is constantly seeing game. I tried to comfort him by saying that our luck would probably come as Hardy's had, but he only shook his head. We walked on in silence, following a deer-path that wound over the sandy ridge and in and out of the little groups of spruces and junipers. Then Jack began, "I wonder if Mr. Hardy-

But he got no further, for there was a crash in the thicket below us, and a large yellow stag dashed out of it. We were at the moment high above him, upon the slope of a barren. From that angle his horns seemed very widespread, palmated and heavy in beam, and curiously like those of a certain type of Norwegian elk.

Feeling pretty sure the head was such a one as I wanted, I fired just as the stag disappeared among the trees. It was a snap shot, and I was.sure I had missed him. I said as much to Jack as we ran forward, and he agreed. We pushed through the drogue of trees after him, and emerging from them we saw a deep valley full of spruces and flanked by a low hillside, but nowhere a trace of the deer. Then a stick cracked, and the stag burst out of the spruces on the opposing ridge nearly four hundred yards away. I managed to fire all the shots in the magazine before he reached cover. " Under him! Under him!" said Jack; but this time I did not think so, for I imagined the caribou had staggered. And so it turned out, for presently we came upon blood splashed on the trees and mosses. Another hundred yards was covered with much caution; then we saw there was no more need of caution, for at the foot of a little hummock the stag was lying quite dead, with three shots in him, while the fourth had hit his horn. As I had taken the one hundred yards sight, both the white and black of it, the fact that I had found the range was one of the luckiest of chances. The 
head, too, pleased me very much, for though not a handsome one, as the stag was past his prime, its curious shape and its weight made it valuable. Above all, both of us felt that the long run of blank days was at last broken.

While we were skinning out the head and cutting up the meat a heavy cloud spread over the sky, and a cold and rainy wind blew up through the trees. Evidently we were in for a thunder-shower, and such are often particularly severe in Newfoundland. We therefore hurried the work and were soon on our way to camp. I was leading, but I found myself every now and then looking back with deep satisfaction at the head and horns that Jack was carrying on his shoulders. We arrived just as the storm burst. In descriptions storms almost always break with " a rattle and a roar." In this case it actually did so. First came a blast of wind, tearing off branches and uprooting dead trees; the blast was followed by deluges of rain and hail. We hurried in beneath our lean-to and tried to start a fire, but the attempt was useless. In the event our failure proved fortunate, for, believing that the fury of the storm and the stinging of the hailstones would probably move any stag that happened to be in an exposed situation, I left Jack struggling with the match-box and walked out to the edge of the thicket with my rifle.

The hailstones were pelting into the river like bullets, beating up little spurts of water, and it was not possible to see more than a few yards. At length, by degrees, the hail ceased, or rather turned to a soft rain, and the long vista of the river came into view. One glance down that vista was enough, for there in the middle distance, about three hundred yards away, a big stag was just crossing. I have seen many caribou, but none in so beautiful an environment. The water did not reach beyond his hocks, and he was splashing through it at a stately walk. Against the almost absolutely black background of the dark water and dripping woods his 
huge white mane showed up splendidly, and splendidly the shadowy form of his mighty antlers.

He was coming from the further bank to my side of the river. I crept forward, keeping as much in cover as I could, but, finding the weed-grown, water-worn rocks too slippery, I lay down behind a boulder and got my focus with the glass. The stag was still in the river, but now rapidly nearing the bank. As soon as I had him in the field of vision I was sure that I had seen the stag before. The formation of the bays was very distinctive, as were the hooked points on the tops. It was undoubtedly the same stag I had been pursuing when I fell a fortnight earlier. I could have shot at him in the water, and it would have been quite a fair shot, as he had by then reached the shallows, but there is a law in Newfoundland against the shooting of deer in the water. It is, moreover, an excellent law, as it prevents the killing of caribou when swimming across the great lakes, for at such times they could easily be overtaken by canoes and their backs broken with an axe, even if they are not shot at close range, for the caribou is a good swimmer and will readily cross a lake four or five miles broad. When swimming they show the whole of the back, and the little scut-like tail sticks up straight. Their extraordinary buoyancy is said to be due to the fact that the hairs of their coats are hollow; at any rate, it is the material that is now beginning to be used for stuffing life-belts. However, although the law against shooting caribou in the water can hardly apply to a stag walking through shallows that barely cover his hoofs, yet it is well to pay respect to a law in letter as in spirit.

I waited till the stag had nearly climbed to the top of the bank, and in consequence I very nearly lost him, for he took the crest with a rush; but just as he topped it a bullet brought him down. He made a dash to re-cross, but fell dead upon a little island of coarse grass. Jack immediately appeared in strong excitement, calling out that he had heard 
the fall of the deer. Our canoe was quickly launched, and we were soon beside its body. I was now convinced that this was the same animal I had seen a fortnight earlier; there was no mistaking the long, even bays. Besides, the spot where I killed it was scarcely more than half a mile from the place where I originally saw it. The bays measured thirteen and a half inches in length of palmation.

After gralloching the stag we left it otherwise untouched in order to photograph it on the morrow, and returned to camp, where we spent one of the cheeriest evenings I can remember, in spite of the dismal weather, the wet ground, and the sputtering fire.

It was while we were at this camp that an Indian appeared, travelling down the bank of the river from the west. After a few minutes' conversation he went on his way, only, however, to return again, this time carrying a caribou head of thirty-one points, which he said he had killed earlier in the year and hidden in a bush near by. He wished, of course, to sell me the horns, offering them for $\$ 5$, and he did not at all understand my refusal to buy them at that or any other price.

"But," he said, "have you not come here into the middle of Newfoundland to shoot stags!" I tried to make him understand that that was precisely why I would not buy, as the horns of a stag which he had shot were of no value to me. The young Indian was silent for a time. "Still," said he at last, " no one would ever know you did not shoot this stag yourself." I pointed out that one person, at any rate, would know, however hard I tried to deceive him, and that he happened to be a person of some importance to me. "Your guide?" suggested the Indian. After I had explained that I meant myself, he stared at me stolidly for a minute, then said he would take the horns to Glenwood and sell them at the railway there. He wound up by asking me if I had shot any stags. My stags were hidden under 
a spruce at the back of the camp. I showed them to him, and, after he had examined them, asked him if he would buy any of them, as some were larger than the one he carried. " I can shoot a stag whenever I want one," he answered, rather gruffly. At last, by way of changing the conversation, I invited him to have a cup of tea. But he refused, and slinging the horns on his shoulders repeated that he could dispose of them at Glenwood, and so, with a surly grunt, walked off out of sight.

We remained in our fortunate camp near the Little Gull River for a couple more days, but during that time saw nothing save one small stag. On the third day Hardy and his men rejoined us. They had met with no luck, and we all agreed that, caribou being so few and far between by the river, we should be well advised to change our ground to the height of land in the direction of Red Indian Lake.

Red Indian Lake is a large sheet of water, one of the largest in the island, and at one time its shores used to be visited by great numbers of caribou. Of recent times, however, the extension of the lumber business and Lord Northcliffe's timber works have driven the line of migration further to the west.

In the previous year Mr. F. C. Selous had travelled in far beyond Red Indian Lake to George IV.'s Pond, a region only once previously visited by a white man, and had told me of the large number of deer which he had seen there. As the crow flies, or, as in Newfoundland one might say, as the wild goose flies, this big, untouched country lay over a hundred miles to the west, but between us and Red Indian Lake spread an immense expanse which, up to that time, had remained almost, if not quite, untried. This was the district that we now made up our minds to travel-a decision the more easily arrived at since we were all a little tired of the conditions under which we had hunted of late, 
the endless watching and waiting, which is so characteristic of September sport in a region of fairly thick woodland.

Loaded with our small necessaries we set out early and walked steadily all day. As we approached the height of land, the country changed in character and became more and more open. Large marshes spread on every side, only broken by little clumps of timber. Of deer we saw but small sign; their broad roads were, it is true, cut deep in the face of the marshes, and the highways along which generations of caribou had wandered wound among the trees, but hardly a recent track was printed upon them. The weather was exceedingly warm, the black flies a distinct nuisance, and very obviously the autumn migration had not commenced. In fact, we learned afterwards that the mass of caribou did not move south that year until well on in the month of October, a fact doubtless due to the prolonged fall and the very hot weather.

But our enthusiasm was to receive a spur, for passing through a strip of thickly-growing spruce, first one and then another of our party picked up cast antlers of great size and weight. These had probably been shed during many and various seasons, but, even so, the very fact that we found horns of such strong growth, bearing from twentyone to twenty-four points each, made us hopeful of meeting in the flesh the giants that had formerly carried them.

Towards evening we made our camp in a little drogue of spruces which formed a landmark for several miles round, and the next morning, leaving Sweetapple to his work in the camp, Hardy and Bob and Jack and I set out in different directions. By evening, on our return, we had sighted thirty-two does and one stag of about twentyfive points, while our comrades had seen thirteen does and a single poor stag.

It must be acknowledged that the time we spent on the high ground, though exceedingly enjoyable, was far from 
successful, only five stags being seen during our whole stay, two of them on our way back to the river. Hardy spied the best of these and generously insisted that I should go after it. However, I was only in time to see it dash away while I was still at some distance, but from the glimpse I had of its horns I think it would hardly have been worth shooting.

As soon as we reached the river we began to hunt in different directions, and on the third day. Hardy killed a pretty head. One afternoon, having left our men in camp, Hardy and I walked to the look-out near which I had shot my first stag. It was a very hot afternoon, the woods filled with a summer-like stillness. We were lying half asleep, and keeping a very desultory watch upon the country, when along a little bare ridge about half a mile away a big stag with an enormous brow antler walked into view and lay quietly down on the highest part of the hillock. The wind was blowing straight from the stag to us, and soon our two telescopes had taken stock of him and we were comparing notes. We agreed that he was worth shooting. Between us and the stag, however, the trees grew very thickly, and the hummock on which he was lying was one of many, so that once we had descended from the look-out it would have been difficult to locate him had it not been for a single gaunt pine, long dead, which towered above the level of the forest about equally distant from us and from him, and this, we hoped, would act as a landmark. Towards it we made our way, but the woodland was so dense that we soon lost sight of it, and so, in addition to the caution necessary to prevent the noise of our passage reaching and alarming the stag, we could catch sight of nothing to give us our bearings, until I imagined I recognised the guiding pine. But unluckily I was mistaken, and consequently we came out of the timber nearly two hundred yards too far to the west. 
Even then no harm need have been done, as the wind was still in our favour, but on coming in sight of the spot where we had seen the animal we found him gone, his tracks proving that he had walked off at his leisure along the spine of the ridge. We followed him for a short distance until the timber became too thick ; then, feeling very crestfallen-for he certainly was a fine stag-we took our way back to the camp. Indeed, as I thought the matter over during the night, the desire to add that stag to my collection became so keen that in the morning, when Hardy proposed to hunt the country in another direction, I returned to the look-out, spent the whole day on it, andsaw nothing at all.

But I would not give up my determination, for I had an idea that the chances of ultimately securing the animal were quite hopeful. He was evidently summering in the thickets, probably within a mile radius of the little broken barren upon which he had appeared. To attempt to follow him up in the wood was useless. The drought had made the floor of the forest like a sounding-board; so closely did the trees grow together that it was difficult to see a dozen yards in any direction. Yet, sooner or later, I knew the big stag must show himself in the open, as he certainly had not been frightened. My only fear was that he might come across my tracks, in which case he would be almost sure to travel away from the neighbourhood, for, as I have said before, caribou are very easily alarmed through the sense of smell.

A second day spent upon the look-out produced no result, though a young stag, the same, so far as I could judge, I had previously seen fording the river, passed within sixty yards. On the third day, after again spending a couple of hours on the look-out, Jack and I moved across to a lower hillock, some three-quarters of a mile to the east. We had not been there ten minutes before Jack saw 
something stirring in the woods, and a moment or two later a stag appeared, feeding slowly along at the foot of a hummock nearly a mile away. He was gone out of sight before we could focus him with the telescope, but his large size and branching antlers led me to believe that he was the very animal I had set my heart on finding.

When I stalked him fortune stood my friend, for we came upon his tracks before we again saw him, and, following them very cautiously for eighty or a hundred yards, presently got a view of the stag, his head hidden behind a bush. When he raised his antlers above the thicket I rejoiced, for he was the same stag, and no other. It was impossible to mistake the enormous solid brow, but I now perceived that the second brow was represented by a little single spike. Still, the horns were so wide and set at such a fine angle that I felt no hesitation about killing him. I shot him through the heart, at about eighty yards, and he sprang forward down the hill and fell dead at the bottom of it.

We were very pleased that our long waiting had issued in success, for to hunt $a$ stag is always more sport than to hunt stags, since to locate and track a particular animal affords greater scope for plan and stratagem.

The season was by this time drawing to a close. Hardy had shot two stags and I three, but as the Newfoundland Government had kindly given me permission to shoot extra specimens for natural history purposes, I intended to exercise my right if by luck I saw a very good stag, but not otherwise. Towards the end Hardy and I hunted together, and some very memorable, though unsuccessful, days we spent up and down the whole range of the Gander country, from the Burnt Woods to Migwell's Brook and Rolling Falls.

We were returning to camp one day, having spent a part of the afternoon within a few yards of a young stag 
which Hardy had photographed, when passing round the edge of a clump of trees I started at close quarters a fine stag with a heavy pair of antlers. Hardy had left me a few moments before to look over a marsh ; therefore, though it was his shot, I had no choice but to shoot at once, as the stag was evidently about to dash away. I put up my rifle and pulled the trigger, with the result of a misfire. The stag, of course, made off at full speed, but I threw out the bad cartridge and got in a second shot, which brought the animal down. I then looked round and found that Hardy, walking silently over the deep moss, had rejoined me, having seen nothing on the marsh. When my rifle missed fire, he covered the running stag with his rifle, but gave me time to re-load and shoot, an action which tells its own story.

This stag carried the best head that I secured during the trip. The next day was the very last day of the season, and on it Hardy came into his own, shooting at sunset, many miles away from camp, a magnificent stag of thirtysix points, by far the finest we either of us secured. Some day, I hope, the hunter to whom it belongs will tell the almost epic story of its slaying, at sunset on the last day of the season.

The following morning we travelled down the river, and so by canoe and accommodation train drifted back into the duller channels of ordinary life. 


\section{CHAPTER IX.}

CARIBOU-HUNTING IN TIMBER AND BRÛLÉE.

$F$ RESH from the barrens and open marshes of Newfound1 land, I must acknowledge that the features of the country where I first hunted in Lower Canada came upon me in the nature of a surprise and a disappointment. It was a region of dense forest-land-thick timber, green timber, spruce, pine, balsam, maple-so close-grown that an average pace of about a mile to a mile and a half an hour was the most one could hope for, and through which the view rarely extended for a hundred yards in any direction. Even the shores of the beautiful lakes were wooded to within ten feet of the water.

At the outset it seemed that in so blind a country, success or failure must be a matter of good or ill fortune. Silent moccasins and straight powder alone must fail (even if one attained the momentary possession of both), without that " beginner's luck" which so often places the novice on a plane with his betters. However, caribou were certainly somewhere in that tangle of trees, deadfalls and moss, and it remained but to try and find them.

The determination to hunt the woodland caribou of Lower Canada first came upon me in the shop of a taxidermist, whither we had made a pilgrimage to examine some moose trophies, and where I saw specimens of New Brunswick and Quebec caribou. There is undoubtedly to 


\section{IN TIMBER AND BROLEEE.}

the initiated eye a peculiar charm in observing and comparing the modifications of horn growth peculiar to different localities. The caribou of the Eastern mainland is a large greyish-brown animal, and while it cannot-though larger in body-rival its Newfoundland cousin in grace and the number of points it carries on its antlers, it yet seems to present a strong individuality of type. One of the heads which I then saw appeared to me very characteristic. The horns, set close together-the spread being only twentyfive inches-were yet exceedingly massive, and, growing as they did almost straight upwards, without much backward curve, presented a most striking appearance. This, added to the reflection which inevitably occurs to all hunters, that doubtless there are finer heads in the woods than are usually brought out of them, made me eager to gain a first-hand experience of the large grey deer.

Edward Atkins, the Maine hunter and moose-caller who accompanied me, had at that time never seen a warrantable caribou stag, and his one desire seemed to be to lose the least possible time in doing so. The upshot was that, five days after our visit to the taxidermist, we had left a good many miles of road, lake and forest-path behind us, and were camped in the neighbourhood of Lac des Neiges.

Part of our journey had been made in company with a buck-board, while we walked ahead between the living walls of bush which formed the border-line of our hunting-ground, and where, here and there at long intervals, a soft dell might show us the track of deer that had ventured into the outer marches. In this connection a disastrous experience fell in the same year to the lot of a friend who, after spending ten blank days in the woods without sight of game, was driving out along the road when he came suddenly within shot of a band of caribou, including five stags - this when the rifles were put away and the cartridges reposing in the packs! One of the men, however, had a 
.303, which he thrust into my friend's hand. The cartridge misfired and jammed. Time itself cannot obliterate the sear of such an episode, which, indeed, has since compelled my friend to carry his rifle along some hundreds of miles of toteroad and bushpath, but without ever again coming face to face with such an opportunity.

One of our halts on the way we made at a small wooden house raised upon piles, in the fly-blown living room of which a kindly, twinkling old lady, bent nearly double with age, gave us, at a small cost, one of the most perfect meals I have ever tasted. The house belonged to one of the small farmers who cultivate little clearings beside the forest-track. These people have an excellent life; they fulfil the dream of George Borrow, who saw himself in imagination, assisted by an enormous progeny, felling the trees and tilling the soil in the virgin woods of America. As a rule, in the case of the French-Canadian, there is no mistake about the progeny. Formerly, I believe, the State bestowed a bounty upon parents whose offspring exceeded the round dozen, but this has been discontinued. The French-Canadians are extraordinarily prolific, and in this connection I can remember arriving at a house and being offered, with a friend, the hospitality of the family bed, which, unless some of the family accepted the alternative of the stable, had already seven claimants.

The French-Canadian family, which lives in or upon the skirts of the woodland, invariably possesses one or more guns, generally muzzle-loaders of the kind that cost from $f I$ to $28 \mathrm{~s}$. in our money, and without which no member of the household above the height of four feet or so ever seems to move far from the door. The result is that the ruffed and Canada grouse which haunt the edges of the bush roads, and which these folk always shoot sitting, are being sadly thinned. Nearer to the cities the Sunday sportsman considers all that flies or is in any way eatable as fair quarry, 
the bird locally known as a " robin " being regarded in the light of a prize.

Recently some speculative individual has introduced five thousand Swiss rifles into the province of Quebec alone. These weapons, which carry a very killing cartridge, are retailed at about $\$ 3.50$ apiece, and at this not exorbitant price the original stock of five thousand has been nearly sold out; so that, although it is to be doubted whether the majority of the purchasers will ever push far afield, it yet is certain that any person walking in the "bush" near a village will be well advised for the future to proclaim his presence by whistling, or song, or in some other definitely human manner. Should he fail to do so, the consequences may easily be disastrous, as the temptation to try his rifle on any creature that moves in the woods may prove irresistible to the local pot-hunter, especially as a moose very occasionally, and whitetail almost habitually, wander about the isolated dwellings of man.

A first trip in any country is invariably fertile in the gaining of experience, and even more so in the paying for it - a truth which we realised some days later when, having searched over a good many acres of ridge and marsh, we failed to find any more material sign of caribou than was afforded by a rare track, and once, in a thicket of spruce, a single tree stripped of its bark and branches some seven weeks previously by a stag cleaning the velvet from his horns.

For the rest, the woods were not wanting in occasional squirrels, ruffed grouse, called in Canada the hardwood partridge, the Canadian grouse, which also owns the local name of spruce partridge, porcupines, and hares. Yet for the most part the Canadian woods are silent, so silent that on a still day you may sit for an hour at a time without hearing or seeing sign of life. One animal only is omnipresent-you come across its work many times a day- 
the beaver. For some considerable time past in the province in which we were hunting, beaver have enjoyed complete protection, and up to a date that is still some years ahead no beaver pelts may legally be sold. This law is, of course, occasionally evaded, and here and there a family of beaver is destroyed, their skins hidden or carried out of the country, rolled in the centre of a pack, to be offered at half their value to some not too scrupulous fur-trader. In the country through which we were travelling, however, no such poaching had taken place, with the result that each stream was dammed, pools spread upon the tracks, and every other alder swamp carried a full head of water. Although there appeared to be a super-abundance of beaver, one rarely saw the animals themselves, but their houses, and the trees, often of astonishing girth, which they had felled, lay in every direction. Sometimes just after sunset, when the musk-rats were out, you caught sight of a beaver or two on their way to their nightly tasks. More frequently, returning late in the canoe along the shore of some lake, you might hear two or three reports, like miniature pistol shots, as the creatures, surprised by the gliding craft, dived with a splash of their immense flat tails.

Having up to this time had no experience with caribou except in Newfoundland, it was difficult to allow at once for the different conditions now to be encountered. Most of our hunting led us into woods where, in Newfoundland, one would never look for caribou, but would endeavour to pass through them as quickly as might be, in the hope of finding barrens or open ground above. But here all the high ground was densely wooded, and caribou-hunting for the first week resolved itself into the watching of marshes, none of which were more than a mile in extent, and all of which gathered around the inlet and outlets of a chain of lakes. After spending some fruitless days at this dull form of sport, I decided to leave the marshes, upon which 
most of the caribou which had been killed in recent years were obtained, and to strike out to the north-west of Snow Lake, where I was informed the country became more open, until forest merged into brûlée (the district having been devastated of forest by fire years before), especially in the neighbourhood of the lake of that name.

The end of October was approaching; we had been hunting and travelling for some little time without having sighted a caribou of any kind. The weather had turned cold, so cold that once or twice, when crossing one or other of the little lakes, we had been glad enough to light a fire upon the shores at which to warm ourselves. It was a cold year, as is proved by the fact that two seasons later, within no great distance of the same place, we were persecuted by black flies up to the I5th of the same month.

On a dull day, with a persistent wind and little showers of snow, we portaged across, and set our canoe upon the waters of Lac Brûlée. We had been informed that there was a camp at some distance along the shore, but before visiting this the whole party, which now consisted of two French-Canadians, Ed and myself, paddled up to the head of the lake, to see whether any caribou might be visible there, or whether we could detect any sign of their recent presence. As soon as we came in full view of the strip of marsh at the lake-head, Ed, sitting in the bow of the canoe, saw a couple of brown objects within a few feet of the water's edge, and I made them out with the glass to be caribou. The wind, fortunately, was in our favour, but the clamorous rising of a number of black duck put the deer on the qui vive. Both immediately ran off among the dead trees. The canoe ceased moving, and watching the deer through my glass, I saw them walk down out of the undergrowth to the open strip by the water. At once we noiselessly paddled the canoe in their direction, and when we once more came in full sight of them, they were not 
much more than two hundred yards away. One was a stag, carrying, as far as I could judge, a head of twelve or fourteen points. I had no wish to shoot such an animal, and finding that Edward was of the same mind, was about to give the order to turn and leave them in peace, when the cook intervened. To him a caribou was a caribou; the question as to whether it was a good or a bad caribou depended entirely upon its fatness, and in a lesser degree upon the accessibility of the spot where it might be shot. Having asked and received leave, the cook picked up Ed's rifle and fired at the young stag. The first shot evidently did not hit him, for after pausing for a moment he went off among the trees, at the peculiar mile-eating gait of his kind, his motions being accelerated by three more shots, one of which struck the water in his very close proximity.

The next day, having at last arrived at our chosen hunting-ground, we were astir before the dawn. Hitherto travelling had occupied a large portion of our time, for the river up which we had just journeyed had not been traversed by canoe before; at least, we could gather no rumour of its having been done, and where the stream narrowed a number of deadfalls made it clear that no one had passed that way for, at any rate, a number of years.

We carried the canoe down to the water before it was light, as there had been a strong frost and the lake was frozen over almost its whole extent. It therefore took us some time to make our way across to the point where the caribou had been observed upon the previous evening. At length the sun rose from a white bank of cloud, giving enough light to make clear some of the features of the landscape. It was very satisfactory to see that at last we had left behind us the seemingly endless green timber, through which progress had been so slow. Now, at last, it looked not only as if the country might hold caribou, but as if one would be able to see them were they there. 
The head of the lake was fed by a sluggish stream which rolled through a wild and marshy valley, the heights on either side being clothed with grey phantom woods of dead trees that had suffered years before from fire, and now rimmed in parts about the lower escarpments with young birch.

Leaving the canoe at the lake-head, we pressed forward. The whole valley was covered with sign of caribou, most of it, unfortunately, over a month old. Had 1 been in Newfoundland, I should have concluded that ten or a dozen animals had been summering in the thickets and the alder-swamps. More than once we cut the yesterday's trail of two animals, doubtless those which had so nearly fallen to the prowess of the cook.

All the morning we walked from height to height, and from vantage-ground to vantage-ground, carefully examining the wide expanses which stretched beneath us. The country was beautifully open, and we saw many horns which had been cast in previous years. These were nearly perfect, not much chewed or nibbled, as would have been the case with similar specimens in Newfoundland. But of living caribou we failed to catch the remotest glance. To make a long story short, we travelled to our hearts' content, finding at least an exhilaration in rapid movement, which we should hardly have believed possible had we not recently spent wearisome days watching the empty marshes about Lac Des Neiges.

The morning and the afternoon were eventless, except for one brief moment when, as we neared the summit of a high hill which we had ascended to reconnoitre the lie of the country, we came upon a pair of cock grouse drumming among the dead trees. As it was unlikely at the altitude we had attained that the noise of a shot could do any harm, we decapitated both, and they formed a very welcome addition to our larder. 
When hunting in the Canadian woods one often falls in with a covey of these birds. The best weapon is a little .22 taking the short cartridge, with which it is generally possible to secure all the birds one wants without in any way alarming the country. Both kinds of "partridge" are ordinarily tame, so much so that at times it is easy to capture them with a long pole and a wire noose, yet at other times they become curiously wide-awake; indeed, I have frequently known them on one day to take no notice of approaching footsteps, while on the day directly following they will hardly allow you within shot. The reason for this has probably something to do with the weather, but what conditions affect them I have not sufficient experience to say.

Climbing over the hill-top, we changed our watershed, and so the day passed almost without incident until late in the evening, when within a mile of camp we picked up the trail of a little band of caribou, which must certainly have passed us unseen earlier in the day. The trail headed towards the lake and disappeared into a large thicket of spruce and alder close to the water. Our chance seemed to have come at last, and, advancing cautiously, we had already, without knowing it, come within eighty yards of the deer, while we had still a quarter of an hour of shooting light left. We paused several times to ensure ourselves against error, and in fact heard the animals feeding and moving, when, to my disgust, our two Frenchmen suddenly appeared in the canoe and began breaking the ice close to the farther shore. They were more than a mile away, but their voices carried with appalling distinctness through the quiet evening, and in another instant there was the sound of a stampede, and, running forward, we found ourselves staring at the slots of the little band of caribou which a minute before had been almost at our mercy.

One of them, as far as we could judge, was a stag; whether his horns would have satisfied either of us it was 
impossible to say. Very likely not, yet we walked back to camp without any stirring of forgiveness in our minds towards the over-energetic cook and his companion.

It may be said that failure is the salt of sport, but salt alone makes a poor meal, and luck at this period really seemed to have deserted us. Search as we might, we saw no more caribou until, coming reluctantly to the conclusion that these most elusive animals had moved on elsewhere, I began to turn my eyes towards England, where it was absolutely necessary that I should arrive by a certain date. Owing to carelessness I had been under the impression that the steamer by which I meant to travel started on a Saturday, which would leave me just enough time to make my way out from Lac Brûlée by forced marches. The particular piece of country through which we had to pass was unknown to any of us, so that when I suddenly, through the medium of an old newspaper, discovered that my steamer left on the Friday afternoon, we lost no time in breaking camp, and by two o'clock set out to strike the nearest trail to civilisation. The first part of our way led us along a portage through a belt of green wood, the very portage upon which the Frenchmen were working when their return to camp proved so disastrous to our hopes.

About four o'clock, when it was rapidly growing dusk, Ed, who was leading along the side of the knoll, suddenly threw down his pack and pointed across the valley. "A caribou stag, and a good head on him. I saw the top half of his horn as he moved," he said. The place indicated was about three-quarters of a mile away. Telling the Frenchmen to set down the canoe and to wait for us until either we returned or they heard a shot, we ran down the hill and along a narrow savanne in the direction of the caribou. It is wonderful the pulsing of the blood and the vigour that the knowledge of game in sight can bring. Speaking for myself, I know that a moment before I had been wearily 
tired, and it was not the loss of my pack's weight that renewed me, but that eagerness which only comes to a hunter when, after days of failure, he sees a chance of retrieving his fortunes at the eleventh hour.

As I said, we ran down the slope and along the savanne at a pace much too great for steady shooting; but the light was fading, and the caribou on his feet, consequently he might wander away anywhere among the clumps and bushes, so that speed was quite in the essence of our undertaking. After we had covered half a mile, we found, to our disgust, that a river lay between us and the caribou. Its edges were frozen, and no more than a dark stream flowed in the middle, but luckily we struck it at a point where the water was not very deep. It was, however, exceedingly cold, and the current quite strong enough as it swirled to our armpits, but we soon broke through the ice and were climbing the bank upon the farther side. Here we found ourselves in what must have been either one large marsh dotted with trees, or a series of little ones. Edward made for a point which should bring us within fifty yards of the spot where he had seen the caribou, but when we arrived there the stag had disappeared. As we were not certain in which direction he was travelling, the only thing to be done was to take our chance of picking up his tracks.

This we did with as little delay as possible, and finding that they led across the wind, circled a little to the left and, passing by a couple of clumps of balsam and juniper, we perceived ahead of us a large fallen tree, and beyond the fallen tree the caribou stag lying down in the open, at a distance of about one hundred and fifty yards. We saw him, and he gained some hint of our presence at almost exactly the same instant. He sprang to his feet as I dropped on my knee and fired through a gap in the roots of the dead tree. I heard the bullet tell, and the caribou staggered; 
but, runring round to get a clear view, I saw he was still on his feet, so I fired again, when the animal fell.

He had been standing broadside on, with the head slightly turned, when I fired the first shot, which I afterwards found had hit him in the neck. When he dashed forward my attention had been fixed upon making sure of him, so that, beyond the first glance which showed me that his left horn was well developed, I had given no more thought to his head. As he fell we both ran up. He lay upon his right side quite dead. Ed seized his horn to turn him over, and then for the first time we became aware that the right antler was missing, though the left was still quite firm.

As the date was the Ist of November it was unlucky that he had dropped his horn, though occasionally it happens that caribou, and especially the larger stags, lose their antlers by this date. This is, however, a matter both of individual and seasonal variation, as in most years these Canadian deer retain their horns as late as the 2oth and even the $25^{\text {th }}$ of the month, though by that time it is probable that the really fine heads, which are always the first to become clean of velvet, have fallen. Of course in the present instance we were bitterly disappointed, but there was no help for it, and the trophy would at least serve as a memory of the trip.

Having skinned the stag, we once again crossed the river and continued our journey. It was almost dark when we struck the waters of the river, and as we had been informed that we should meet with no quick water on our homeward journey, we concluded that we might safely push on after dark. As a matter of fact, until half-past ten that night we continued to strike rapid after rapid, several of which, in the obscurity, necessitated wading, so that it was an uncommonly chilly party which finally built a large fire upon the bank, round which we crouched 
till dawn. As the night had been very still and cold, it was no surprise to us in the morning to find the still water, which now became more frequent, frozen to a depth of some inches. The ice was too thick to break, so we were forced to cache the canoe and pursue our journey on foot. It had previously been arranged that a buck-board should be in waiting at a spot where a permanent camp was pitched, some thirty miles closer to our hunting-ground than the nearest village. Between six and seven hours' walking along open hillsides brought us to the tent, about which we found a number of men, among them our driver, who, it appeared, had met with an accident and damaged his eye in an altercation with a compatriot. We ate a hasty meal, after which the driver, who seemed to be a somewhat surly individual, informed me that he had no intention of taking the road, and it was close upon three o'clock before I overcame his reluctance.

Leaving my French-Canadians behind at the camp, Ed and $I$ set out in the buck-board, and as, with the exception of the time we had spent by the fire during the night, we had been continuously on our feet for twenty-eight hours, we were extremely glad of the lift. Our comfort was, alas ! of very short duration, for we had not made more than four miles when one of the off-side wheels became jammed among the rocks and broke to pieces, and had to be replaced by a green sapling. While the repairs were being executed, $\mathrm{Ed}$ and I spied four ruffed grouse, three of which we shot.

When we set out again with the crippled buck-board we found ourselves still twenty-one miles from the nearest house, to be reached in the dark over an exceedingly rough forest-road, continually cut by water-courses, over which pine-log bridges had been thrown some fifteen years previously, but most of these had been destroyed by time and weather to the extent of becoming an obstruction rather than a help. Our food, too, had given out, and had it not 


\section{IN TIMBER AND BROLEE.}

been for a meal from a barrel of pickled pork which we found in a disused logging hut, we could hardly have succeeded in accomplishing the distance in time. It was nearly 2 a.m. when at length the seemingly endless road wound into a clearing from which the sound of cattle feeding was one of the most welcome we had ever heard.

Refreshed by food we pushed forward, leaving the buckboard to follow, and by four o'clock the same afternoon I was aboard my steamer. As I bade Edward farewell, we agreed that, as it was obviously impossible to accept defeat, we would do our best to retrieve our failures in the following September.

This plan, as well as a mortifying sense of my late illsuccess, was much in my mind during the intervening months; but l'homme propose, and the September trip was ultimately made impossible owing to an invitation to play cricket in Philadelphia and Canada. As the dates of our matches covered the whole of the month of September, it was not until the 6th of October that Edward and I once more found ourselves on the road for the arena of our return match with the caribou. This time fortune had been our friend, and, thanks to the kind help of Mr. F. W. Ross, I had received permission to hunt over a niew country. My only regret was that Mr. Ross was not able to accompany me, as he had originally intended.

Our journey was marred by one of those irritating occurrences of which a hunter over-eager to reach his huntingground is apt to become the victim. I imprudently hired a "rig" and its driver, who happened also to be the owner of the vehicle, without bargaining as to price, as the man had recently worked for some friends at the usual tariff. Hence it was that, early on the road, I was faced with the ultimatum, "Either you give me fiftee dollars, or I take your baggage no furder," a state of affairs hard to bear without temptation to resort to a course which, 
besides being unlawful, may well be undignified, especially as in the present instance the carter possessed the four feet eleven physique of a Mousqueton. However, we finally slept upon our differences, and the following morning my suggestion that we should make an immediate start was acted on without argument. At the end of the trip the matter, of course, cropped up again, and I was a good deal overcharged, but not to the extent of the first impudent demand for fifty dollars.

We met with many delays on the road, all occasioned by Mousqueton's horse, which not only kicked a hole in our canoe, but later overturned the buck-board and its load, and finally conceived so strong a dislike to its owner and its duties as to necessitate our packing every pound of our outfit along the last miles of our way. However, everything has an end, and Edward and I at last pitched our camp on a hillside above a small and, I believe, nameless river. Mousqueton departed to resume, as we heard afterwards, his differences with his steed, had the worst of it, and in the end was forced to abandon his buck-board and to return the thirty miles whence he came on foot.

Meantime, on the Ioth of October, Ed and I had everything "straightened away to rights," and by three o'clock of a beautiful autumn afternoon we set forth to look over the ground. Chastened by the experiences of the previous year, neither of us hoped for any immediate success, but we were resolved to offer an unsparing sacrifice of time and trouble at the shrine of the Wood Gods.

As we walked on that afternoon the country looked likely, but so had the country round about Lac Brûlée when we visited it in the previous season. Our way to the north-east of our camp led us through a wide valley shut in to the west by a high ridge of mountains and to the east by a smaller range. Not far from the centre of it rose three mounds exceedingly suited for reconnoitring purposes. 
The low ground was brûlée, and among the grey barkless trunks which stood or leaned at every conceivable angle, young trees, spruce, juniper, maple and poplar had grown to a height of some ten or twenty feet.

It was quite late and the sun had already sunk when from the top of the first of the woody mounds Ed spied six caribou. The glass showed us that there was not a shootable stag among them, which, however, did not prevent our approaching and watching them while the light lasted. Then we crept away, leaving them undisturbed, and returned to camp, where I fear we slept little, so eager were we for the coming day; the up-shot, of course, being that when morning actually came we did not awake until the sun struck on a large kettle and reflected a blinding beam across my eyes. Breakfast was swallowed in double quick time, and immediately after it we were on the move through the glorious upland air. There had been a frost during the night, so that the sun sparkled upon a thousand thousand points of crystal light, as though some giant hand had flung a shower of diamonds across our little portion of the world. The sky was deep blue; across the lake a loon cried; the air mounted to one's brain; it was good to be alive.

Of course our objective was the First Look-out, as we named the spot from which we had sighted those six most inspiring caribou on the previous evening. We spent a blank hour there, and we walked on from knoll to knoll without a glimpse of deer, but passing, nevertheless, a couple of torn and broken trees upon which big stags had cleaned their horns earlier in the season. At length we arrived at a point from which the valley-bottom dropped some hundreds of feet into a cleft, where it debouched upon another and a deeper valley, through which a dark and slow-moving river wound its way, lost itself in a reedy dead-water in the middle distance, and, emerging, flowed away to the northeast. 
We stood on the rocky back-bone of the hill, with a view of a couple of miles, an ideal place for spying, and soon both glasses were at work. At first the wide vista seemed tenantless, but after half an hour I saw something move, found it again with my telescope, and made out a doe caribou advancing up a savanne about half a mile away. Seven does soon appeared, following the first, and then a stag, obviously young; lastly, the tops of a pair of large horns slowly rising until the whole body of the stag was visible. I pointed him out to Ed, who observed delightedly that he was better than the one-horned fellow, and "Will we be getting after him ?" The question needed no answer. We slipped over the open rock unobserved and commenced to run down the fissure on the farther side. As we did so I felt Ed's hand catch my shoulder. "Look there! there upon the hill!" he whispered.

I looked, and I do not think I have seen a more splendid sight. Down the steep slope on the opposite side no less than eighteen caribou were galloping. At first I thought something must have frightened them. But no, evidently they had seen their friends in the valley and were rushing down to them, or, I should say, the does were endeavouring to do so, for on the outskirts of the herd a great, heavybodied stag, whose horns seemed to touched his flanks, was struggling to check the revolt of his harem. But no sooner had the eighteen reached the level ground in the gut of the valley than the leading doe slowed to a walk. The revolt was over; they moved on, and in the neighbourhood of a little pool of dark water which lay at the head of the savanne the whole herd were lost to sight.

We immediately pushed on under the kindly cover of the ridge, the wind seemingly in our faces, everything in our favour, and on the best of terms with our hunterluck. But this happy state of things was, as usual, of but short duration. To the north-east lay the bare hill- 
side, where the eighteen had come upon the scene, and the ridge under which we were creeping formed, as we soon discovered, a mere tongue of rock that must be crossed. As we climbed it I felt that ominous tickling of the wind, first on one ear, then on the other, and finally on the back of the neck, which means an eddy. The herd we had first seen were, or we judged ought to be, about a hundred yards away over the ridge and about abreast of our position; the eighteen which had descended the hillside at an equal distance straight ahead of us. If either band were startled both would in all probability stampede. We therefore scrambled down from the ridge and began to circumvent its base. I was sure the deer must have been startled; but no, in another twenty yards I caught a glimpse of the white hind-quarters of a doe, and I saw that her head was down and that she was feeding. So far good, but the wind was shifting more and more to the side, and, as it seemed, must carry the hint of our presence to the herd we had seen first. No cover was now left to us but the final knob of the ridge, a bare hummock of reindeer moss, and at the very moment we attempted to crawl to it the wretched doe raised her head. We both lay still and were making up our minds to a long wait when, to our relief, she fed quietly out of sight.

The course was at last clear, so, abandoning without regret the attitude of the serpent, which is exceedingly irksome in nine inches of water, we closed in rapidly, and a few moments found us lying panting against the soft mossy side of that most grateful hummock. Before I looked over, I knew that we were near to our quarry ; the peculiar clicking noise that caribou make with their hoofs was startlingly distinct, as well as the suck of their feeding. As I peered over the top of the hummock my eyes met those of the doe, with no more than eight paces between us. Her companions were all round her, and she at once gave 
the warning half-cough, half-snort. As they ran off, look as I would, I could not see the stag. I imagined he might be behind, but no, there he was at last, not in the marsh by the pool, as I had expected, but standing apart about forty yards away to the left. He was startled, but uncertain in which direction to break, and with his head turned from me.

He sprang forward as I fired, fled with gigantic strides across the savanne, and the spruces shut him in. At the same instant I caught sight of Ed tearing across to the right, as it seemed, in pursuit of the does. I ran to the left and immediately overtook the stag. He had come to a standstill, and was swaying as he stood. A second shot passed through his heart, and I was soon beside him, admiring the massive round horns of a very heavy head.

While thus pleasingly engaged, I heard a shot, followed by others, and running over the ridges towards the sound, I soon saw, about three hundred yards off, a big stag twisting round and round, finally to fall with a crash among some stones on the top of the hard ground on the other side of the savanne. Half-a-dozen does were galloping wildly round, but they all made off as Ed came out from among the trees. It appeared that, as I fired at my stag, he had perceived the second herd of caribou, and slipping along the ridge, got in a shot at the master-stag at three hundred yards. The stag, not knowing where the bullet that struck him came from, ran in towards Ed, who fired at him again as he galloped, hitting him twice, and bringing him down. All the shots were long, and rendered difficult by the bush through which the stag was moving.

The head had fine tops and bays, and was beautifully palmated, and of quite a different type to my rugged specimen. Curiously enough, we each preferred the other's trophy. This did not, however, prevent our feeling to the fullest that sense of satisfaction resulting from success; which is one of the few joys that have absolutely no reaction. 
In the evening, as we walked back to camp with our trophies, we saw no less than thirty-two does, but only a single stag, a small one, which, of course, we left in peace.

Having made so lucky a start, and having by the terms of our licence only the right to shoot one more stag apiece, we now, as was to be expected, at once set our standard very high, a fact to which a fine stag which we sighted next day probably owed his continued lease of life. This stag we spied from the First Look-out, and we were close enough to him to inspect his head almost point by point. He was warrantable, but lame of the off fore-leg, a circumstance that may have caused his horns to deteriorate, for although he carried twenty-two or more points, he seemed to be deficient in beam, which would certainly be probable were he recovering from a wound sustained during the previous year.

That evening heavy snow fell, and I proceeded to improve the occasion by losing our only axe. I was cutting wood, and foolishly struck the axe into a log before carrying ancther back to the camp half a mile away. Being delayed there by some task, it had become too dark when I returned to find the axe, and by next morning it was buried under a foot of snow. We experienced a difficulty in getting our fire started, and indeed were quite as cold as was comfortable before we succeeded in making a blaze. By great good fortune I found the axe after breakfast. The snow, which overlay the country, was, of course, an open advertisement of the daily and nightly movements of the game in our neighbourhood, but the results of inspection were disappointing. A cow and a calf moose, a large number of doe caribou, and only two sizable stag-tracks were all that a hard day's travelling showed us. Judging by the large number of rubbing-trees, there must have been many stags in the valley earlier in the year, and it seemed probable that the 
summering deer had taken their departure, in which case our prospects of further success were poor.

The first snow, which in the case of moose and whitetail is the hunter's greatest opportunity, is, as regards caribou, of less aid. It is of course possible, by systematically following caribou tracks, to come up with deer from time to time, but as a rule, in open country it is hardly worth the trouble to do this. The reason is that caribou are such insatiable travellers at this season when they are migrating that, in eleven instances out of twelve, the hunter gains nothing by tracking them but a good appetite and an extended knowledge of the country.

Next day we at first hunted separately, and Ed saw, but did not shoot at, a young stag of nineteen or twenty points, while I had to be content with watching a small herd of nine does. About three in the afternoon, however, having once more joined forces, we were shivering in the lee of a rock upon the Second Look-out, when a stag appeared, moving through the brûlee at a distance of about a mile and a half. A transient gleam of sunshine showed up his horns, and after making a detour to clear the wind, we set about the business of the stalk. The country in which we had seen him was tolerably thick, that is, one might pass within fifty yards of a stag and remain quite unaware of his presence. As we had a long round to make, we were lucky to see anything of him again, and in all probability should not have done so had he not been accompanied by three does and two fawns, one of which gave us the line just as we were on the point of getting to windward of them. As it was, a doe with her fawn became alarmed, and made off, followed by the rest. The stag, however, happened to have wandered some two hundred yards away from the herd, which just enabled me to run across, cut him off, and fire a bullet which broke his shoulder. He carried a nice even head of twenty-five points, and had-a 
very rare merit in the mainland stags-two moderately developed brow-antlers.

After the death of this stag good fortune seemed to desert us, for hunt as we would, either together or singly, neither of us came upon a shootable beast. But a second fall of snow helped us once more to see what game was about, and this time our suspicions became certainties, for the only tracks to be found were those of does, and all headed in one direction. We consequently decided to forsake the high ground where we had been so successful, and to descend to the lower levels.

Upon those more than breezy heights there are few spots suitable for camping, and as we had but a blanket apiece, we spent far too many of our nights in a reek of in-blown wood-smoke. Our eyes suffered quite severely, Ed being almost smoke-blind at one time, in view of which it was fortunate that our chances of shooting came early in the trip. Although I dislike cold as much as other people, I still more dislike a stove in the tent, and until absolutely forced by the weather will have none of it. Even in the chilliest autumn a lean-to and an open fire are, in my opinion, far preferable.

That night it turned very cold. Indeed, though comparatively early in the season, I7th October, the frost which then commenced held until the following spring, so that we had some difficulty in reaching the open water of the lake. But at length we made our way through, and set up a snug camp in the green timber.

No sooner were we settled than a gale, accompanied by heavy snow, began to rise, and the wind blew so fiercely that it brought us out of our blankets in the small hours to cut away all overhanging branches and to lop the surrounding trees. With these we made a zariba, inside which we were exceedingly comfortable. From this date we returned to camp each evening with increasing pleasure, after 
long and fruitless journeys through the snow that covered the treacherous windfalls.

So day after day passed, until there remained but one before that on which I had arranged with Mousquetonin default of a better man-to come out with his waggon and another horse, that he described as " good and confiding," to convoy us back to civilisation. We determined to make one final effort, although it seemed that the caribou had migrated some days earlier towards their winter quarters.

In the morning, however, Ed woke strong in the belief that the gods would send us adventures, because he had dreamed a lucky dream. I myself was not without hope, for the last day has proved time after time lucky for my companions and occasionally for myself. Sure enough, about eleven o'clock, as we were walking through a grove of young birch which grew upon a steep hillside, we cut a broad trail, evidently made by a band of some twenty caribou. It was clear from the tracks that they were feeding, and consequently our hopes became very bright. Amongst a medley of small slots ran a series of large ones that could only have been made by a big stag.

After some twenty minutes' tracking, during which the herd most considerately travelled in a straight line up-wind, a dozen grey shapes sprang out of the bushes above us, immediately followed by three more from some spruces and alders some hundred yards in front. One of these three was the stag. I do not think I should have shot at him, for as he made off his horns looked slight and thin. As it turned out I should have been quite wrong in letting him go. However, Ed, who had a clearer view, saluted him three times without hesitation. It was not an easy chance, but following his trail we found blood, and behind the next clump of bush we came again in sight of the wounded animal, when another shot rolled him down the hillside. 


\section{IN TIMBER AND BRULEE.}

When we examined him he proved much more worthy of powder and shot than I had imagined, for he carried a beautiful pair of upstanding horns, showing twenty-one points, with both tops and bays well developed. In fact, in some ways I considered this to be the best trophy either of us obtained, though all four were excellent heads, quite above the class that is best described as warrantable.

It was, as can be imagined, with much rejoicing that we bore him back to camp, where we arrived about four o'clock, and two hours later we heard the powerful voice of Mousqueton hailing us from the darkness across the river. 


\section{CHAPTER X.}

FURTHER DAYS AFTER MAINLAND CARIBOU.

$\mathrm{T}$ the autumn of I908 I chanced to have the oppor1 tunity of making a third trip after caribou in Eastern Canada, and, though I had already enjoyed such capital sport in the two former ones, I found strong inducements to undertake another when my friend Mr. F. W. Ross asked me to accompany him on a short venture into the woods. Firstly, I was glad to go with him ; and my second attraction took the shape of a cast horn that had been brought in by Mr. Ross some years previously. In weight and size this one enormous antler far surpassed any I had ever seen, and although the length of time which had elapsed since the finding of the huge horn made it more than probable that the skull which once carried it lay whitening long since upon some hillside, yet I could not help hoping the deer was not a unique specimen, but that others, his sons and grandsons perhaps, might possibly approach, if they did not rival, the record of their forefather, for the country Ross proposed to hunt was situated in the same district as that in which the mighty antler had been cast.

Our party consisted of Ross, Dr. Campbell Howard of Montreal, and myself, together with Ed Atkins and three French-Canadians. With us travelled a couple of buckboards to carry our baggage for the first sixty or seventy miles of our journey. We made the distance in two days and a half over an execrable road, but its difficulties brought 
us the consoling assurance that travellers upon it must be few and far between. On the second day the leading horse, a powerful grey, fell through one of the many rough timber bridges which occurred at intervals along our route, but by a miracle it escaped unhurt.

Shortly after this misadventure the whole party was arrested by the calling of a cow-moose within a mile of the road. We halted, and everyone listened while the strange bellowing cry was repeated at the least a dozen times, and was then, to our great satisfaction, answered by a bull. As it was yet early in September, and the rut had consequently only just commenced, the chances were in favour of the bull being a large one.

Ross and Howard generously insisted that I must try my luck; so, accompanied by Ed, I went off in the direction of the sound. Almost immediately on leaving the road we found ourselves entangled in a long strip of alders, but beyond this the forest appeared to thin. We pushed our way through the alders and, wading a small brook, took a line at right angles to the road, when we again heard the cow calling and the bull answering, but by this time they had moved into some very thick timber. Here, the wind being in our favour, we soon got within a hundred yards of the bull, which continued trampling and grunting. But the growth of the forest was so dense that it was impossible to see more than a few yards in any direction, so we were unable to locate the cow. Had the wind been steady, or had the bull been alone, we could in all probability have approached near enough to see him, but after advancing for another fifty yards we were forced to stop and wait. The smell of the bull was quite perceptible even to the human nostrils, but all sounds had ceased, and it was evident that both animals had become suspicious and were listening. The silence was broken by what we imagined to be the movement of the cow, which had circled 
round with the manifest intention of finding out the facts of her surroundings by getting to windward of us. At this moment we heard the bull again behind a thick bush within thirty yards, for the cow must have communicated her alarm to him, and at once there followed a series of crashes as the couple decamped. Abandoning all precautions, we ran forward in the hope of cutting off the moose, but failed to catch sight of them, as their tracks showed us they had turned and escaped over a wooded ridge, leaving us to retrace our footsteps sorrowfully to the road, along which we followed the buck-boards, reaching camp long after dark. We were both much disappointed at our failure, the more especially as, had the moose been in almost any other part of the forest save the thicket into which they had wandered, I should almost certainly have got a shot; and the matter was made still worse by the fact that, as far as we could judge by the marks that the bull in his flight had made with his horns on the trees and bushes, he must have carried antlers with a very fine spread.

We marched next day from the Mort, or death of the waters, where we parted with all the buck-boards but one, the monotony of the morning being only broken by the shooting of a few Canada grouse which we killed with a toy-like .22 rifle. On arriving at the river where Ed and I had waited for our waggoner the previous year, we found my old camp tenanted by a number of Frenchmen who were fishing. Some of them were, to say the least of it, very heavy men, and I could not help wondering how their horses had managed to transport them over the bad road, for, judging by the fishermen's figures, they certainly looked incapable of walking very far. They were clothed in a variety of colours, one wearing a football jersey in broad green and white stripes. They were a delightfully cheery party, and had had excellent sport, they told us, catching trout up to $7 \mathrm{lbs}$. in weight. 
At this camp we left our last buck-board with the horse and man belonging to it, and had I only been able to foresee the experience through which the man-whom we had named Charlie because of the extraordinary resemblance he bore to a mutual friend-was shortly to pass, I would very gladly have stayed with him. Some days after the Frenchmen had taken their departure, Charlie awoke early one morning, and looking out from the ruinous log hut which he and the horse occupied, he saw a very fine bull moose, attracted, as he opined, by the presence of the horse, walking slowly across the clearing towards the hut. Charlie appears for a time to have been interested in the "gros gros orignal," but later felt " puzzled what to do, as the moose continued to come nearer and nearer, and Charlie had no weapon but a revolver, though, as he explained to us afterwards, "If I had had a permission, I could have killed him with that, he was so close." The upshot of the incident was tame, for Charlie frightened the moose away, though he assured us " had it not fled when I shouted, I should have fired, even without a permission." Questioned as to the size of the bull, the repeated, "Gros, gros!" and his story was borne out by the tracks of a large moose that Ed and I found on the other side of the river.

However, we were blind to this impending event as we bade good-bye to Charlie and made our way up the river and across the lake, arriving a little before sunset at my camp of the previous year, from which Ed and I had shot three caribou. That night we were attacked by myriads of biting insects, but whether they came out of the grass on which we lay, or were an importation we brought with us from the last outlying points of civilisation, we never knew.

On the following morning it was agreed that Ross, Ed, and I should hunt the farther part of the ground, leaving Howard, with Gagnon, on the nearer of the two look-outs. 
For the first two hours we saw but little sign of deer ; then, just before coming to the hill under which we had shot two stags in 1907 , we spied some does, and soon after Ross and Ed saw a stag. We took a short circuit for the wind, and then lay down behind a bush to hold a council of war. As I was walking behind the others, I had not caught sight of the stag. I may mention that before starting I had said that I wished to shoot a stag with big tops, while Ross had expressed his preference for a symmetrical head and brows. Having spied the stag with his glass, Ross now turned to me and told me it had fine tops, and most unselfishly insisted on my taking the shot. We crawled a little nearer, and for the first time I gained some view of the horns. I could only see them very partially through close intervening bush, as the stag was lying down.

There were, however, ahead of me, some well-placed spruces, one of which appeared to be within a hundred yards of the caribou, and to this I accordingly made my way, and from it achieved a good sight of the tops of the antlers. They looked magnificent and much finer than any I had yet seen. As the stag's body was hidden I rose behind the spruce and, taking a rest against it, pressed the trigger. The animal was lying with his head towards me, and at the impact of the bullet his legs flew up into the air, then came to earth again, and he never moved afterwards. The head carried twenty-six points, and though one bay was completely missing, the tops made up for that, and in fact the antlers were most remarkable.

Ross and Ed were delighted, Ed saying, "That's the best tops in Canada," which I believe to be very nearly true, at least as far as that part of Canada is concerned. Before skinning the head, we all went down to drink water from a stream that ran under the hill to our right. I happened to be leading, and we had not gone a hundred yards before I caught sight of a couple of does coming over the 


\section{FURTHER DAYS.}

crest of the ridge ahead. These were quickly followed by others; they had been disturbed, no doubt, by the sound of my shot. The does came running in our direction, and were quite close to us, though still unconscious of our presence, when a stag appeared. As he moved across at about a hundred yards Ross fired, killing him instantly. He proved to have a nice symmetrical head of twentyseven points. As the does fled, they ran almost over the body of the first stag, which lent them new wings of fear, so that they soon vanished among the trees.

We were naturally very pleased with such a beginning to our trip, and after removing the two heads and performing the usual rites, we went on. We had luck with us that day, for within a mile we saw another stag on the side of a hill opposite, about four hundred yards away. I did not think he had a good head, but Ross and Ed were of a different opinion, so while I remained where I was they followed to make sure. After about half an hour they returned, having obtained a much closer look at the stag, which confirmed them in their estimation of the head, at any rate to the extent that it showed better horns than the stag already killed by Ross. But, unluckily, the animal led them into a strip of green timber, where stalking became very difficult, and they lost him. I blamed myself for this disappointment, as, had I not depreciated the head, Ross might have closed in with and shot the deer when he first became visible.

Although we hunted the rest of the day we met with no more stags, and on returning to camp we found that Howard had had a poor day. He had spent it, according to Ed's and my advice, sitting on the top of the First Lookout, and having seen from that point of vantage nothing more interesting than an unlimited quantity of black fly, but not a single deer. In the evening I went with Ed down to the lake to try a moose-call, but the wind was 
so strong that after two or three calls we abandoned the attempt.

This first successful day seemed to have used up our share of good fortune, for hunt as we would, neither Howard nor I saw anything at all, while Ross and Ed came across a couple of small stags not worth a bullet.

At the time I was not particularly keen to shoot another caribou, but wanted very much to fall in with a moose, and, with this aim in view, I went out alone and spent a good deal of time hunting in the green timber. One day, when out with Ed, I heard some shots, and on returning to camp, found that Howard had killed a splendid stag, with horns that for length and beauty could scarcely be equalled in that part of the country. He was hunting with Ross and Gagnon, and all of them were watching a savanne, when a herd of upwards of thirty caribou, including no less than five stags, suddenly came out of the woods. Of the five stags, two were far superior to the rest, the one which Howard killed, and another, at which Ross only just failed to get a shot, and which made off into the dense woods. This latter had, they told me, a very symmetrical head with one brow shovel at least, and very nicely developed bays and tops. Both described it as carrying quite as fine a head as the one Howard secured. With any luck Ross should have had an excellent chance of shooting this stag, but it was frightened off by the loud untimely cries of triumph with which their French attendant hailed the fall of the caribou killed by Howard.

After this, I went out for two or three days without gaining a glimpse of any deer, and none of the party were more fortunate, so that we began to fear that the big stag which they had seen must have moved off into another district. At last, on the 3oth of September, Ed and I, travelling to the farthest point from camp, found a hillside which was covered with moose-sign, and there on the 
following day Ross and Ed saw two moose, one of which Ross killed, the other Ed wounded and lost. Ross's moose head showed a spread of forty-eight inches, and carried a good, even head.

On the 2nd of October I went out alone and spent a day so full of incident that it is worth describing at length, more especially as it is typical of a favourable day in that region. Snow had fallen during the night, and lay all over the country to the depth of about six inches. This made my walks towards the Look-outs and onwards very interesting, as it was, of course, possible to see exactly what the movements of the deer had been since about one o'clock in the morning. Two large stags had crossed quite near the camp, but as the rest of the party had arranged to hunt the ground to which these passed I did not follow them. About a mile from camp a moose, either a cow or a young bull, had travelled down from the north and gone on into grten timber. By the time I had been walking for an hour or so I suddenly saw a big caribou stag moving at a good pace through the brûlée.

From the direction in which he was travelling there appeared to be a good chance of cutting him off near a large maple, the red leaves of which made a beautiful and easily-distinguished mark in the landscape. I hurried to this tree, and had not long to wait before the stag came trotting in a leisurely manner into view and not more than a hundred yards from me. He had a good pair of horns, with two very long and well-developed bays, but both the brows were represented by mere lengthy spikes, and the tops were practically destitute of points. I therefore let him pass in peace and slipped away, crossing the backtrail of the stag, and made my way to a ridge of low barrens and hummocks, over which the walking was very bad, as the snow had drifted into the hollows. Half an hour's floundering brought me to the open highlands where I 
had shot the stag on the first day of hunting, and as there were several tracks crossing and re-crossing this spot, I sat down in the lee of a spruce out of the cold wind.

I had hardly been there more than five minutes when my eye was caught by the brownish-grey form of a doe caribou heading towards me out of a patch of woodland lying to the north. She came forward at a good pace, followed by a second doe, and presently a stag emerged. At first it seemed the deer would come right up to where I was waiting, but while still several hundred yards away the leading doe changed her course and began to trot rapidly in a direction that within a very short distance would bring her to leeward. There was nothing for it but to change my position; fortunately a deepish gully offered good cover, and I ran down it for about a quarter of a mile, expecting every moment to see the deer in full flight. As soon as I was sure that I had crossed the front of the advancing caribou and was safely to windward of them, I crept out of the gully and under the shelter of a bulky hummock. The two does and the stag had, however, now disappeared, and, after watching for a few minutes, I began to go forward up-wind, purposing, if possible, to cut their trail. I had not gone more than fifty yards before I saw the flank of one of the deer disappear behind some trees about two hundred yards ahead, and the next instant the does walked out into the open. They were no more than a few yards from my trail, and as I knew, once they got wind of it, they would be scared away, I sat down and made ready to shoot if, on seeing the stag, I should think it worth while to do so.

Before many moments had passed the stag advanced slowly from the trees. He looked very big to my eyes, for these mainland caribou are larger and heavier in the body than their Newfoundland cousins, though their horns, 
in spite of their weight, are seldom so symmetrical and show far fewer points. A glance now assured me that the stag, moving with his slow, rather cow-hocked action from the trees, bore an unusually fine head, and the idea occurred to my mind that he might be the very stag that Ross and Howard had seen with the big herd. He walked on and then stood still, giving me a steady broadside shot. I heard the bullet strike, but the next moment the whole three had stampeded, the does doubling back and running between me and the wounded stag. When they had passed and I could get in a clear shot, I fired again twice. On receiving the second bullet the stag fell.

When I reached him he was quite dead, and I realised that I had shot a truly fine specimen of the mainland deer. On his horns, which were well grown and palmated everywhere, save in the case of one brow, I counted twenty-nine points, a greater number than is usual with a Canadian woodland caribou. After cleaning the stag I left him lying, meaning to take off the head and head-skin on my return, and once more pursued my way. Just over the summit of the rise beyond, and within five hundred yards of the spot from which I had shot the caribou, I came upon the tracks of what must have been a very large bull moose. Had I not seen and killed the caribou, I should certainly have gone over this rise, and on the open ground behind it would probably have seen the moose standing at not more than a hundred yards distance. Even though I had secured the big caribou, I am afraid I wished for a moment that I had never laid eyes upon him.

Knowing, however, that moose do not invariably travel far even when startled, I took up the trail and followed it through a marsh scored all over with caribou tracks, and then climbed the flank of a hill, of which the slopes were covered with birch trees. On the farther side of this hill the bull had gone into some thick green timber, where 
under the trees little snow had penetrated, and the trail in consequence was hard to take up. But $I$ found his tracks where he had paused between two trees, and the displaced snow on the branches bore clear evidence of a spread of horn of over four feet. In another half-mile I lost the trail completely, and it was nearly two hours later before I crossed it again on the edge of an alder swamp at the base of the hill, where, after a prolonged struggle with the alders in which I certainly was not the victor, I gave up the pursuit, and, passing back along the lower ridges of the hill, came to a well-defined path that had been cut by migrating caribou. This path was as wide, though not as deep, as those which I had seen in Newfoundland; it presented but few fresh tracks, and, within no very long distance, debouched on the shores of a small lake, where I ate my lunch, and while $I$ ate I heard a cow moose call several times on the mountain side above me.

I passed the early part of the afternoon searching for this moose, but when I at last discovered her tracks I found she was alone, and therefore not worth following. I next mounted to the top of the hill through the wood of birches, and leaving this behind I came out above it on the open hill-top, from which I gained a wonderful view. I was about to enjoy looking round the country when, almost straight below me, I caught glimpses through the trees of a herd of caribou, seemingly about thirty strong, on a marsh round the edge of which $I$ had in the morning tracked the moose. I came down the mountain at my best speed, and was soon lying hidden among the bushes within a hundred yards of the caribou. A very fine stag escorted this herd, and also two smaller ones; the big fellow's horns, though long and beautifully curved, were comparatively light. I lay watching them for upwards of an hour before an outlying doe winded my trail of the morning and 
gave the alarm, when the whole herd made the water fly in their frantic retreat.

When they had gone I returned to the dead stag and cut off his head and carried it back to camp, after a day's hunting during which I saw more game within a few hours than ever before or since in the same short period of time in Canada. I found that Howard had killed another caribou. Ross, Howard, and Gagnon all agreed that the stag I had shot was the same that they had seen a week earlier.

The death of that stag completed my limit for the year under the Provincial licence, and the rest of my trip was taken up in searching for moose.

Notwithstanding all my efforts, and those of Ed, I failed to see a single one. Had the weather been less boisterous, we might perhaps have tempted in a bull by calling; the nearest approach to success came to us one evening, when I called and a bull answered. He was coming in most promisingly when one of the French-Canadians in the camp, a mile and a half away, began to chop wood. We neither saw nor heard any sign of the moose again.

During the following day, when we were all walking on the trail, Ed spied a caribou stag a long way in front. This animal Ross and he stalked successfully to within long range, when Ross killed it-a nice head of twenty-seven points.

With that shot our trip concluded. In the course of it we had secured seven caribou and one moose; the caribou, and especially Howard's, were much above the average.

The Canadian woodland caribou is, as I have said, considerably larger than its Newfoundland relative. The difference is especially noticeable in the hoofs, and the mainland animal weighs at least a sixth as much again as its congener. The horns are very distinctive, being narrow 
in spread, heavy and carrying fewer points; the bays also are set very close to the brows. It is, however, always dangerous to dogmatise about horn-growth in caribou, and I can only ask my readers to draw their own conclusions from a comparison of the horns of the two races figured in this book. 


\section{N D E X.}

Alaska, I85.

Alces americanus gigus, 185 .

Andes, hunting in the, 34-57.

Argentino, Lake, 46, 48, 55 .

Arnold, George, 87, Ior, II2.

Atkins, Edward, I68-181, I83-186, 215, 2I9-220, 223-245, 249.

Atkins, Will, I86.

Auroch, Russian, I49.

Avalon, Peninsula, 85 .

Bears, in Labrador, 69, 70 ; in Norway, I49; Polar, 82.

Beaver, Newfoundland, 218.

Bernard, Stephen, 193.

Birchy Island, 197.

Blair, Mr. H., II2.

Boleadores, 32.

Borrow, George, 2 I6.

Broomfield, Mrs., 63, 64 .

Broomfield, Sam, 62, 65-67, 73-75.

Bromley-Davenport, Mr., I3.

Bralée, Lac, 2 r9.

Buenos Aires, city of, 25 ; Lake, 55, 56 ; Mount, 48.

Burnt Hill, 200.

Butt's Brook, II4, I4I.

CANADA, moose hunting in, $168-189$; caribou hunting in, 2I4-25O.

Caribou hunting in Canada, $2 \mathrm{I}_{4}-25 \mathrm{O}$; in Labrador, $58-80$; in Newfoundland, 83-III, II2-I4I, I9O213.
Cattle, wild, Patagonian, 46-52.

Cavy, Patagonian, 2O, 2I, 53.

Chico, River, 55.

Chimango, Patagonian, 2I, 42.

Cod fishing, 81, 82 .

Condor, Patagonian, 42-45.

Conn, River, 193.

Cooper's Brook, I98.

Corancho, Patagonian, 2I, 42.

Crowe, Mr., I92.

DAvis Inlet, 59, 72.

Deer Lake, Io8.

Deseado, River, I2, 36.

Dewey, Sam, II2, II3, I2I, I24.

Dewey, Walter, II2, I2I, I24.

Dogs, Argentine, 25-30 ; Labrador, 63, 64; Norwegian, I45, I47, I48, I52, I65, I66; Patagonian, 42.

EdWARD, Lake, I86.

Elk, and moose compared, I84; hunting in Norway, I42, I44-I67, I87.

Elson, George, 73.

Eskimos, 66, 77.

FalkLand Islands, 47.

Fanny's Harbour, 60-62, 73.

Fenix, River, 38.

Fox, Patagonian, I2, I3.

Gallegos, 55 .

Game laws, in Canada, I74, I83; in Newfoundland, 83, 86, I94-I95, 
206 ; in Norway, II8, I42-I43; in the United States, I83.

Gathorne-Hardy, Mr. G. M., I52, I54, I66, I84, I87, I9I, I92, I96, I99, 20I-202, 204, 208-2I3.

Gander, Lake, 196.

George, River, 59, 67.

George IV. Pond, 208.

Glenwood, I92.

Glovertown, 86.

Goose, Patagonian, 2I, 22.

Grouse, Labrador, 69; Canadian, $217,240$.

Guanaco, Patagonian, I3-15, I9-20, 23-25.

Guemal, Patagonian, 36, 39-42.

Guns, sale of, to French Canadians, 2I7.

HARE, Labrador, 75; Canadian, 217.

Harrigan, Cape, 62.

Hebron, 77.

Hellgate Cliffs, 43.

Hinds, Eleazar, 169.

Hopedale, 76.

Horses, Patagonian, I6, I7, 54-55.

Howard, Dr. Campbell, 238, 239, 24I, 243-244, 249.

Howley, 84, 195.

Hubbard, Mrs., 72, 73, 80.

IBIs, Patagonian, 53.

Igloo Camp, 7I.

Indians, Micmac, 85, I3I, I93; Montagnai, 66, 72; Nascaupee, 66; Ona, 3I ; Tehuelche, I2, I4, $25,32-33,35$.

Island Pond, I03.

JACK LANE's Bay, 62.

Jack's Brook, 67, 68.

Jannasch, Dr., 78.

Jeddore, Joe, 193.

Jeddore, Nicolas, I98.

Jeinemeni, River, 38.
John's Pond, 85 .

Jones, Humphry, 48.

KAGUDEK. I93.

Kennedy, Sir William, 92.

Krabbé \& Higgins, Messrs., 54.

Kristian, I45, I66, I67.

LABRADOR, caribou-hunting in, 5880 ; inhabitants of, 60,77 ; nature of country, 68 .

Lane, Old Man, 68.

La Plata, 45.

Lapps, I43, I66.

Lewis, Reuben, I93, I98.

Loon, Labrador, 70, 71 .

Los Antiguos, River, 38, 56.

Low, Dr., 59.

Lynx, Newfoundland, 9 I.

MAGELLAN, Straits of, I2.

Maine, I86.

Makkovik, 77, 78.

Mathias, $157-159$.

Merganser, Labrador, 63 .

Middle Ridge, II2, I26, I3I, I93.

Migwell's Brook, I98.

Millais, Lake, II4.

Millais, Mr. J. G., 58, 90, I08, note.

Mollygojack, Lake, I 38 .

Moose heads, sale of, I87-I88.

Moose-hunting and calling, in Canada, I68-I89, 239-240.

Moravian Mission in Labrador, 5960, 77-78.

Musters, Captain, 25, 33.

NAIN, 77.

Nansen, Dr., 77.

New Brunswick, I85, I86.

Newfoundland, caribou-hunting in, 83-III, I9O-2I3; fauna, 82; game laws, 83,86 , 194-196, 206 ; inhabitants, 86, I3I; Marine and Fisheries Department, 82 ; railways, $84,87-89$; scenery, III. 


\section{INDEX.}

News, transmission of, in Patagonia, 20.

Northcliffe, Lord, 208.

Norway, elk-hunting in, I42-167; farming conditions, I43, I44 ; game laws, II8, I42-I43.

OKaK, 77.

Osprey, Labrador, 7I.

Ostrich, Patagonian, I7-18.

Ounaniche, 198.

Patagonia, general aspect, II, I2 ; fauna, $12, \mathrm{I}_{3}, 53,54$; hunting in, I3-53; means of travelling, 5457.

Perrett, Rev. W. W., 76.

Philadelphia, 227.

Pino, Lac, I86.

Piramide, Mount, 38.

Porcupine, Canadian, 217.

Price, Mr. W. W., I68.

Prowse, Judge, 87, 92.

Puerto Madryn, 55.

Puma, Patagonian, 30, 31.

Quebec, 8I.

RED Indian Lake, 208.

Reid Company, 58, 59.

Rendell, Mr. R. G., 59.

Rimouski, I85.

Rodseth, Peder, I45-I64.

Rolling Falls, I97.

Ross, Mr. F. W., I68, 227, 238-239, $24 \mathrm{I}-245,249$.

ST. Jонn's, 59, 8I, 82.

Saltatha, 7 r.

Santa Cruz, 55.
Saunders, Bob, I37, I92, 197.

Seals, Labrador, 63 ; Newfoundland, $8 \mathrm{r}$.

Selous, Mr. F. C., 85, 90, 132, I85, 208.

Senguerr, valley of, $14,22$.

Sheep, Patagonian, $3 \mathbf{I}$.

Simon, Mr. I. H., II3, II4.

Snipe, Patagonian, 24.

Soulis Ann, I96.

Spracklin, Captain, 6r.

Square Island, 60.

Squirrel, Canadian, 217.

Sweetapple, Ned, I92, I98.

Sylvester, Mount, 193.

TERra Nova, 87-89, II 3 , I4 $\mathrm{r}$.

Transport charges, extortionate, $227-228$.

Trelew, 55 .

Virginia Lake, steamer, 73.

WAAG, Mr., 38.

Walrus, Labrador, 74.

Weapons, Patagonian native, 32 .

Wells, Frank, 87, ror, II2.

Wells, Jack, 6r, 68, 76, 86, 90, 9297, 99, I02, I09, I I2, I20, I25, I26, I29, I39, I40, I92, 20I-204, 206, 2 II.

Widgeon, Patagonian, 24 .

Windy Tickle, 75 .

Wolf, Newfoundland, 86 ; Norwegian, I48, I49; Patagonian, 30, 52.

Woody Island, I9r.

Wynyard, Captain, II2-II5, II7, I2O, I25, I26, I32, I4O, I4I.

YeLLOW shank, Labrador, 62. 
Established 1798

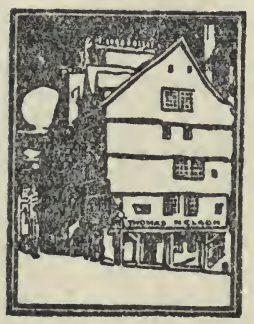

T. NELSON \& SONS, LTD. PRINTERS AND PUBLISHERS 
A FEW OF THE RECENT ISSUES IN NELSON'S EXTENSIVE LIST OF POPULAR NOVELS. PUBLISHED AT Is. 6d. NET.

SALUTE TO ADVENTURERS. John Buchan. MARRIAGE. H. G. Wells. RODNEY STONE. A. Conan Doyle. THE WITCH OF PRAGUE.

F. Marion Crawford.

THREE MISS GRAEMES.

Miss S. Macnaughtan.

PRESTER JOHN. John Buchan. PAUL PATOFF. TRENT'S LAST CASE. THORLEY WEIR. THE RIDDLE OF THE SANDS.

Erskine Childers. THE WILD GEESE. Stanley J. Weyman. THE OLD WIVES' TALE. Arnold Bennett.

T. NELson \& Sons, Ltd., London, Edinburgh, \& New York 
A FEW OF THE RECENT ISSUES IN NELSON'S EXTENSIVE LIST OF POPULAR NOVELS. PUBLISHED AT Is. 6d. NET.

JIM OF THE RANGES. G. B. Lancaster. FORTITUDE. Hugh Walpole.

A ROLLING STONE.

THE SEA HAWK. MARRIED OR SINGLE? THE RED COCKADE. Stanley J. Weyman. THE MANXMAN. Hall Caine. THE LOO'T OF CITIES. Arnold Bennett. SAILORS' KNOTS. FOUR FEATHERS. E. A. W. Mason.

T. NELSON \& Sons, LTD., London, Edinburgh, \& New York. 



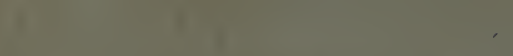

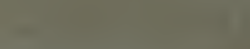

1

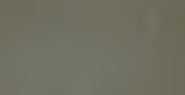

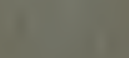

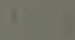

-

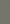

in

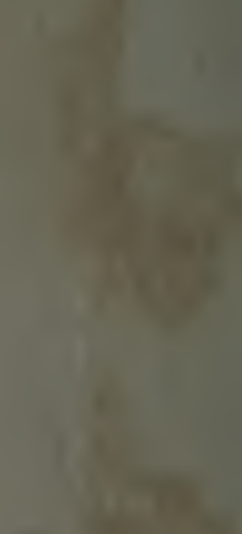

(1)

(4)

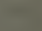
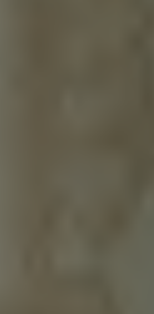

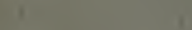

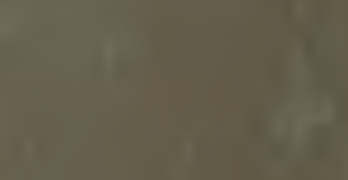

(1) $x^{2}=1$
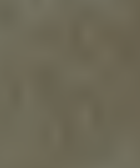


\section{YB $1025 i$}

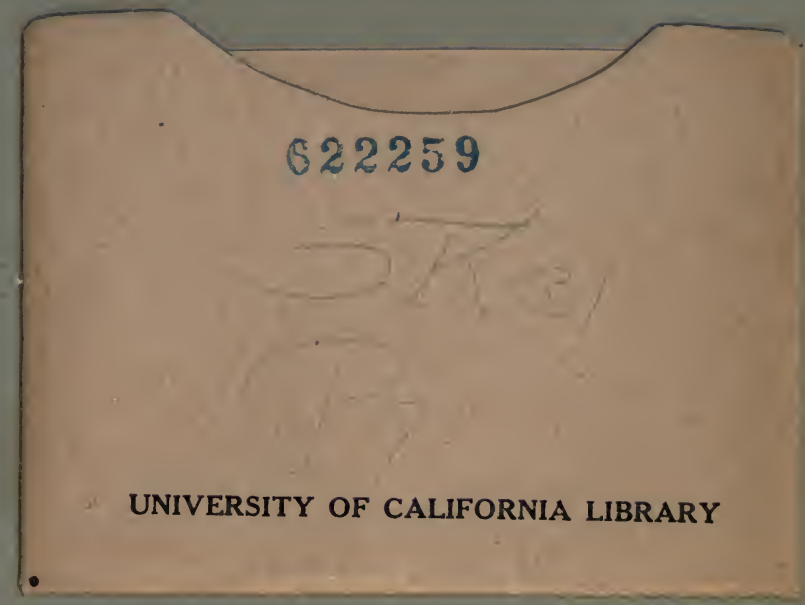


